\title{
14. CALCAREOUS NANNOPLANKTON: LEG 14 OF THE DEEP SEA DRILLING PROJECT
}

\author{
Peter H. Roth, Department of Geology, \\ Swiss Federal Institute of Technology, Zurich, Switzerland, and \\ Scripps Institution of Oceanography, La Jolla, California, \\ and \\ Hans Thierstein, Department of Geology, \\ Swiss Federal Institute of Technology, and \\ University of Zurich, Switzerland
}

\section{INTRODUCTION}

Calcareous nannoplankton occur in 73 of the 95 cores recovered at ten drill sites during Leg 14 of the Deep Sea Drilling Project. Figures 1 and 2 show the location of the sites and the age of the cores recovered. In the samples studied calcareous nannoplankton assemblages range in age from Lower Aptian to Pleistocene. Lower Aptian nannoplankton occur in one core (135-9) from the Eastern Atlantic. Upper Aptian assemblages were recovered in two holes: one on the eastern side and one on the western side of the Atlantic. Albian sediments were found in one core underlying a long section of Cenomanian (Site 137). Short and incomplete sections of Santonian to Coniacian, Campanian and Maestrichtian were cored on both sides of the Atlantic. Only a few cores of Paleogene age were recovered. The Neogene sections cored are also incomplete with gaps in the Middle and Upper Miocene. Tables 2 and 3 summarize the zonal assignment and age of these cores.

Light microscopy was used mainly to study the calcareous nannoplankton assemblages. Some selected samples were also studies by scanning electron microscope. Light and scanning electron micrographs of the same specimen were obtained using the method described by Thierstein, Franz and Roth (1972).

Samples are designated according to the usual format the site number with letters (A, B, etc.) for any additional holes at the same site-core number, section of core, level from the top of section.

The authors wish to thank M. N. Bramlette of Scripps Institution of Oceanography for his generous help throughout this study and for stimulating discussions on calcareous nannoplankton taxonomy and biostratigraphy. We are grateful to H. R. Hohl and E. Kuhn-Schnyder of the University of Zurich for the use of the scanning electron microscope at the Botany Department, University of Zurich, Switzerland.

\section{CENOZOIC CALCAREOUS NANNOPLANKTON ZONES}

In general, calcareous nannoplankton zonations were first established in land sections. Hay et al. (1967) reviewed the Cenozoic nannoplankton biostratigraphy and defined zones for the Paleogene and for the Pliocene to Recent. Bramlette and Wilcoxon (1967) introduced a zonation of the Oligocene to Middle Miocene interval. The study of nannofossils from cores recovered by the Deep Sea Drilling Project resulted in various zonal schemes for the Cenozoic.
Gartner (1969) described new zones for the Late Miocene to Recent based on deep-sea cores from the Atlantic and the Pacific. Martini and Worsley (1970) and Martini (1970) presented a simplified summary of the Tertiary and Quaternary calcareous nannofossil zonation. Martini and Worsley define the boundaries of their zones only on the highest or lowest occurrence of a single species. Bukry and Bramlette (1970) and Bukry (1971) use many closelyspaced first and last occurrences of species and the composition of the assemblages to define their zones. The resulting zonation is more reliable because it is not wholly dependent upon the presence of a single species and is therefore not so much affected by reworking, contamination, selective solution and paleoecologic control of species distribution.

Martini (1971) summarizes the Cenozoic nannofossil zonation, gives ranges of important species and correlation of nannoplankton zones with planktonic foraminiferal and radiolarian zones. Bukry (1971) describes his "tentative multiple concurrent range zones" in detail indicating the composition of the assemblages and the first and last occurrence of species which can be used to draw the boundaries of the zones.

The zonation used in this report incorporates zones first proposed by Bramlette and Wilcoxon (1967), Bukry and Bramlette (1970), Bukry (1971), Gartner (1969), Hay et al. (1967), and Martini and Worsley (1970). The whole assemblage is taken into consideration when assigning a sample to a certain zone; wherever possible the boundaries are defined by more than one paleontological event.

A fairly complete Pliocene to Pleistocene section was recovered from Hole 141 which might be useful for more detailed studies. Only spot cores were taken from the Miocene sections drilled in many holes. The Lower Oligocene section cored at Site 144 seems fairly complete although it is resting on Middle Eocene. Only spot cores were recovered from the Middle and Lower Eocene and from the Upper Paleocene.

\section{Pleistocene}

\section{Gephyrocapsa oceanica Zone}

The base of this zone is recognized by the earliest common occurrence of Gephyrocapsa oceanica and a marked reduction in abundance of Pseudoemiliania lacunosa and Coccolithus doronicoides. Gephyrocapsa oceanica, Cyclococcolithina leptopora, Helicopontosphaera 


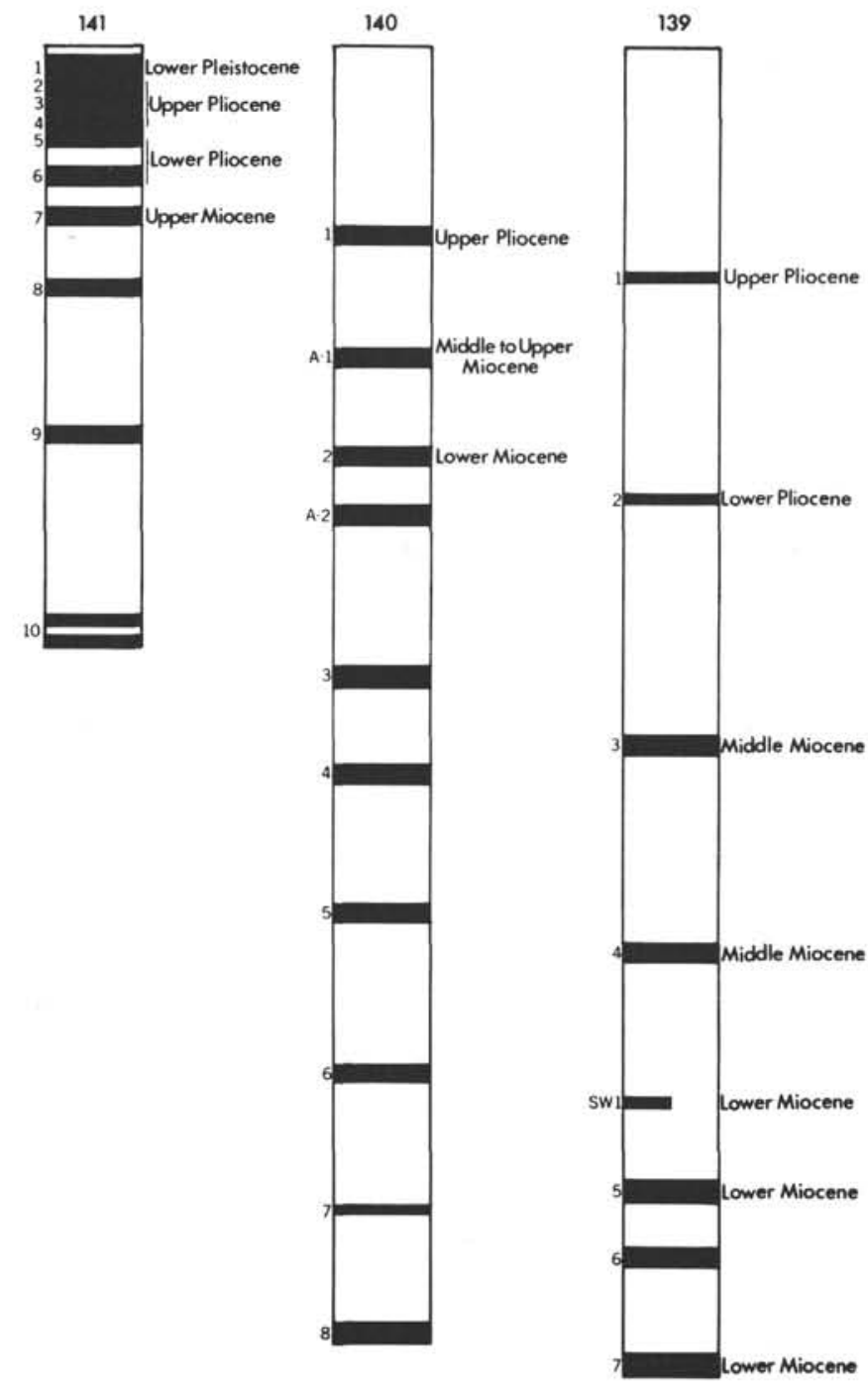

Figure 1. Eastern Atlantic sites drilled on Leg 14 of the Deep Sea Drilling Project and series and stages in cores based on nannoplankton assemblages.
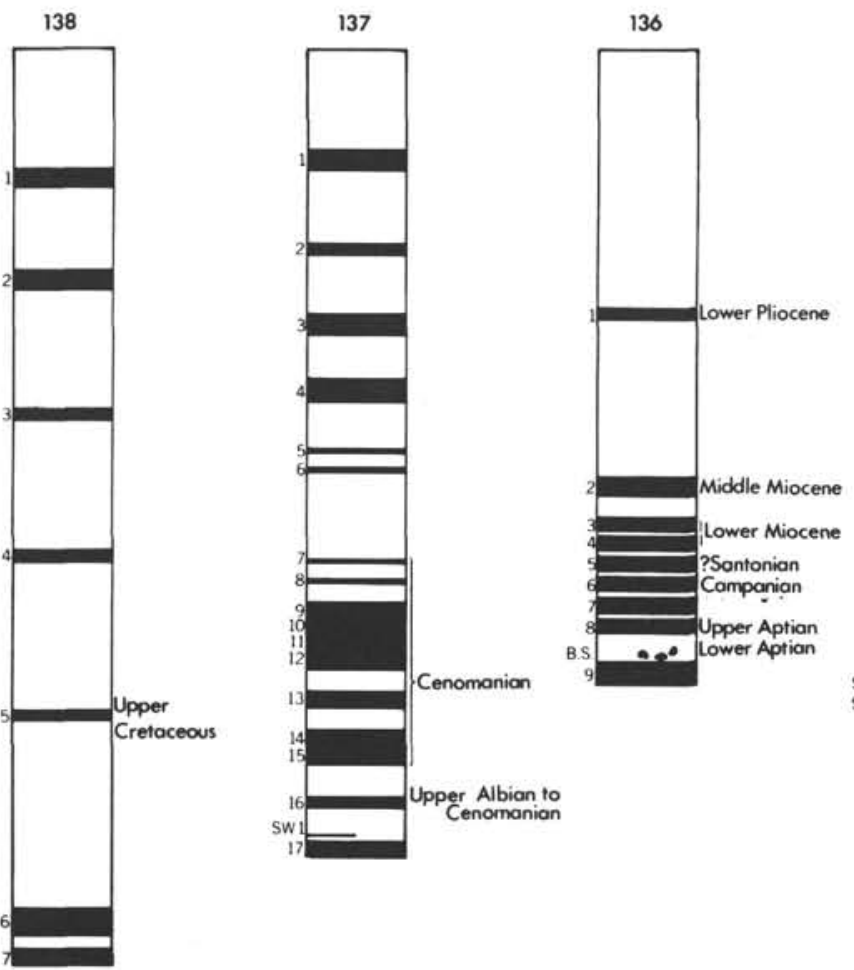

135
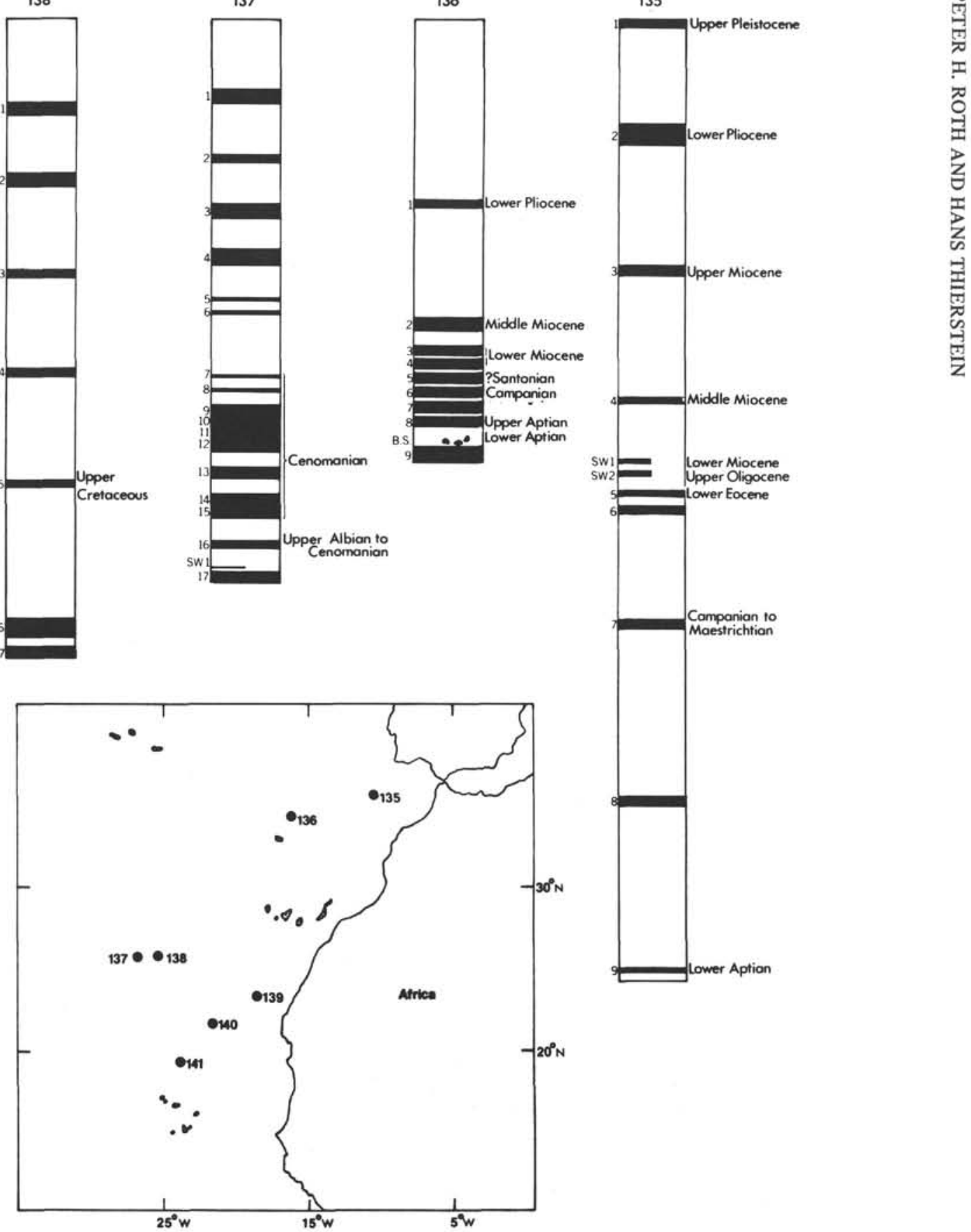
144

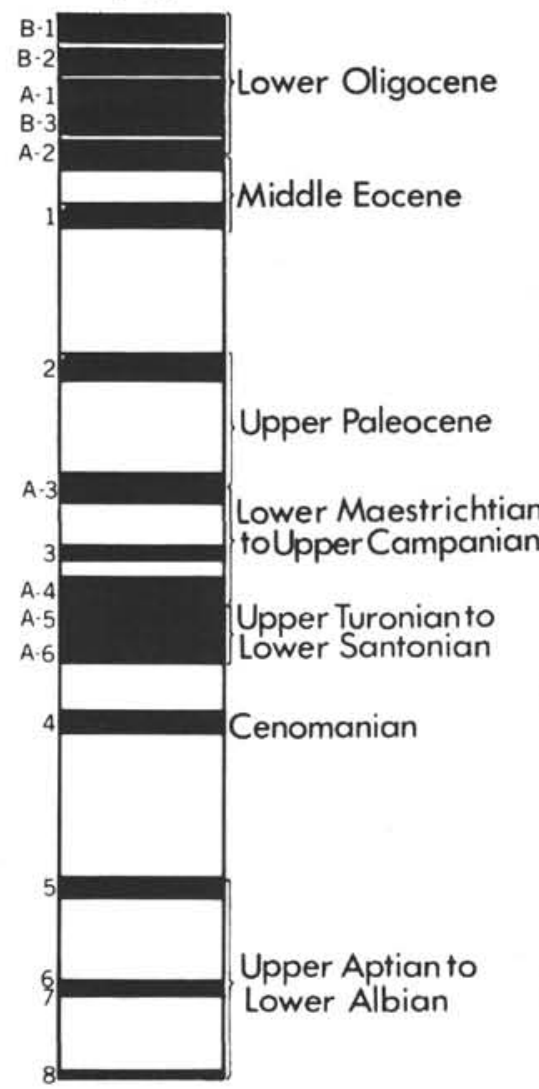

142

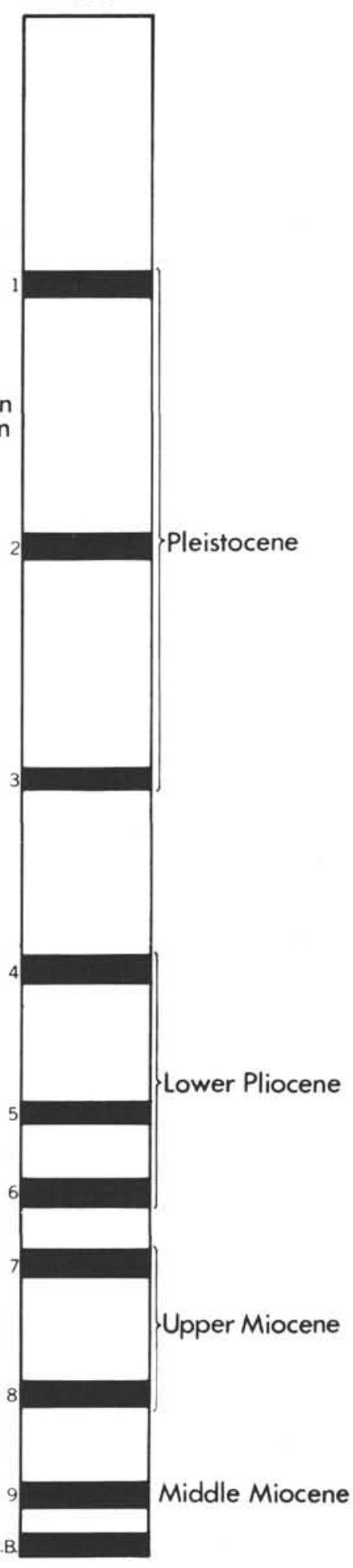

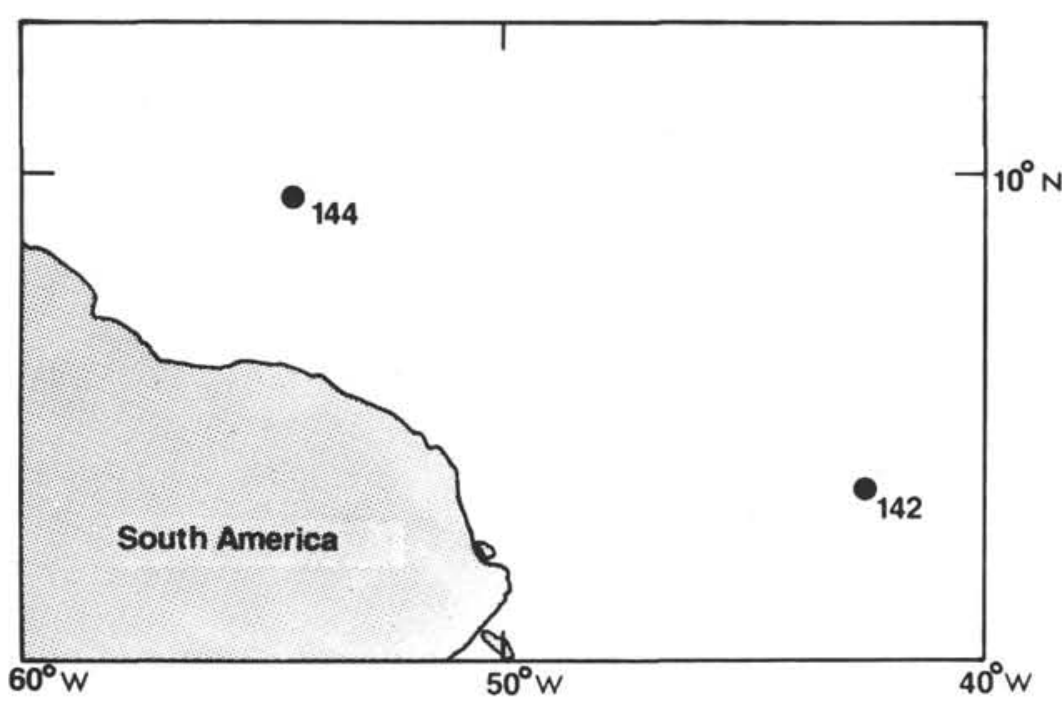

Figure 2. Western Atlantic sites drilled on Leg 14 of the Deep Sea Drilling Project and series and stages represented in cores based on nannoplankton assemblages. 
TABLE 1

Nannofossil Species Considered in This Report

(listed in alphabetical order of the species epithets)

Sphenolithus abies Deflandre in Deflandre \& Fert, 1954

Reticulofenestra abisecta (Müller) n. comb.

Corollithion achylosum (Stover) Thierstein, 1971

Tetralithus aculeus (Stradner) Gartner, 1968

Corollithion acutum Thierstein n. sp. (Plate 2, Figures 1-9)

Braarudosphaera africana Stradner, 1961 (Plate 16, Figure 18)

Lithraphidites alatus Thierstein n. sp. (Plate 3, Figures 1-8)

Hayesites albiensis Manivit, 1971

Pontosphaera alta Roth, 1970

Helicopontosphaera ampliaperta (Bramlette \& Wilcoxon) Hay, 1970

Ceratolithus amplificus Bukry \& Percival, 1971

Sphenolithus anarrhopus Bukry \& Bramlette, 1969

Parhabdolithus angustus (Stradner) Stradner, 1968 (Plate 6, Figures 14-18; Plate 7, Figure 1)

Oolithotus antillarum (Cohen) Reinhardt in Cohen \& Reinhardt, 1968

Scapholithus apertus Hay \& Mohler, 1967

Parhabdolithus asper (Stradner) Reinhardt, 1967 (Plate 7, Figures 7-17)

Cylindralithus asymmetricus Bukry, 1969 (Plate 12, Figures 19-22)

Discoaster asymmetricus Gartner, 1969

Eiffellithus augustus Bukry, 1969

Discoaster barbadiensis Tan Sin Hok

Sphenolithus belemnos Bramlette \& Wilcoxon

Microrhabdulus belgicus Hay \& Towe, 1963 (Plate 3, Figures 10, 11, $15,16)$

Discoaster berggrenii Bukry, 1971

Broinsonia bevieri Bukry, 1969 (Plate 14, Figures 14-17, 22-29)

Chiasmolithus bidens (Bramlette \& Sullivan) Hay \& Mohler, 1967

Braarudosphaera bigelowi (Gran \& Braarud) Deflandre, 1947

Zygrhablithus bijugatus (Deflandre) Deflandre, 1959

Discoaster binodosus Martini, 1959

Watznaueria biporta Bukry, 1969

Reticulofenestra bisecta (Hay, Mohler \& Wade) Roth, 1970

Discoaster bollii Martini \& Bramlette, 1963

Watznaueria britannica (Stradner) Reinhardt, 1964

Discoaster brouweri Tan Sin Hok, 1927

Nannoconus bucheri Brönniman, 1955

Hayesites bulbus Thierstein n. sp. (Plate 2, Figures 20-23)

Discoaster calcaris Gartner, 1967

Chiasmolithus californicus (Sullivan) Hay \& Mohler, 1967

Sphenolithus capricornutus Bukry \& Percival, 1971

Triquetrorhabdulus carinatus Martini, 1965

Lithraphidites carniolensis Deflandre, 1963

Coccolithus cavus Hay \& Mohler

Discoaster challengeri Bramlette \& Riedel, 1954

Cruciellipsis chiasta (Worsley) Thierstein n. comb. (Plate 6, Figures 8-13)

Zygolithus chiastus Bramlette \& Sullivan, 1961

Markalius circumradiatus (Stover) Perch-Nielsen, 1968

Rhabdosphaera clavigera Murray \& Blackmann, 1898

Nannoconus colomi (De Lapparent) Kamptner, 1938

Watznaueria communis Reinhardt, 1964

Helicopontosphaera compacta (Bramlette \& Sullivan) Hay, 1970

Staurolithites compactus (Bukry) Thierstein, 1971

Zygolithus concinnus Martini, 1961

Cretarhabdus conicus Bramlette \& Martini, 1964

Biscutum constans (Gorka) Black 1959 (Plate 8, Figures 13-18)

Chiasmolithus consuetus (Bramlette \& Sullivan) Hay \& Mohler, 1967

Marthasterites contortus (Stradner) Deflandre, 1959

Cretarhabdus coronadventis Reinhardt, 1966 (Plate 5, Figures 1-9)

Cylindralithus coronatus Bukry, 1969 (Plate 12, Figures 23-26; Plate 13, Figures 1-5)

Toweius craticulus Hay \& Mohler, 1967

Cretarhabdus crenulatus Bramlette \& Martini, 1964 emend. Thierstein, 1971

Prediscosphaera cretacea cretacea (Arkhangelsky) Bukry, 1969 (Plate 16, Figure 5)

Prediscosphaera cretacea ponticula Bukry, 1969 (Plate 15, Figures 16-19; Plate 16, Figures 1-4)
TABLE 1 - Continued

Ceratolithus cristatus Kamptner, 1950

Staurolithites crux (Deflandre) Caratini, 1963

Chiastozygus cuneatus (Lyul'eva) Cepek \& Hay, 1969 (Plate 12, Figures 1-6)

Rhomboaster cuspis Bramlette \& Sullivan, 1961

Cruciellipsis cuvillieri (Manivit) Thierstein, 1971

Arkhangelskiella cymbiformis Vekshina, 1959

Microrhabdulus decoratus Deflandre, 1959

Podorhabdus decorus (Deflandre) Thierstein n. comb. (Plate 4, Figures 7, 8, 10-13)

Discoaster deflandrei Bramlette \& Riedel, 1954

Campylosphaera dela (Bramlette \& Sullivan) Hay \& Mohler, 1967

Broinsonia dentata Bukry, 1969 (Plate 14, Figures 6-13)

Podorhabdus dietzmanni (Reinhardt) Reinhardt, 1967

Glaukolithus diplogrammus (Deflandre) Reinhardt, 1964 (Plate 11, Figures 1-5)

Pontosphaera discopora Schiller, 1925

Sphenolithus distentus Bramlette \& Wilcoxon, 1967

Ellipsolithus distichus (Bramlette \& Sullivan) Sullivan, 1964

Pontosphaera distincta (Bramlette \& Sullivan) n. comb.

Discoaster divaricatus Hay in Hay et al., 1967

Gartnerago diversum Thierstein n. sp. (Plate 15, Figures 9-15)

Coccolithus doronicoides Black \& Barnes, 1961

Discoaster druggii Bramlette \& Wilcoxon, 1967

Zygolithus dubius Deflandre in Deflandre \& Fert, 1954

Cribrosphaerella ehrenbergi (Arkhangelsky) Deflandre, 1952

Glaukolithus elegans (Gartner, emend. Bukry) Thierstein n. comb. (Plate 10, Figures 16-20)

Corollithion ellipticum Bukry, 1969

Parhabdolithus embergeri (Noel) Stradner, 1963 (Plate 9, Figures 1-6)

Cruciplacolithus eminens (Bramlette \& Sullivan) Hay \& Mohler, 1967

Campylosphaera eodela Bukry \& Percival, 1971

Coccolithus eopelagicus (Bramlette \& Riedel) Bramlette \& Sullivan, 1961

Arkhangelskiella erratica Stover, 1966

Helicopontosphaera euphratis (Haq) Roth, 1970

Tranolithus exiguus Stover, 1966 (Plate 10, Figures 6-10)

Discoaster exilis Martini \& Bramlette, 1963

Chiasmolithus expansus (Bramlette \& Sullivan) Gartner, 1970

Reinhardtites fenestratus (Worsley) Thierstein n. comb. (Plate 8, Figures 1-12)

Lithastrinus floralis Stradner, 1962

Cyclococcolithina floridana (Roth \& Hay) n. comb.

Cyclococcolithina formoas (Kamptner) Wilcoxon, 1970

Marthasterites furcatus (Deflandre) Deflandre, 1959

Tranolithus gabalus Stover, 1966 (Plate 10, Figures 1-5)

Chiasmolithus gigas (Bramlette \& Riedel) Gartner, 1970

Tetralithus gothicus gothicus Deflandre, 1959

Tetralithus gothicus Deflandre subsp. trifidus Stradner in Stradner and Papp, 1961

Chiasmolithus grandis (Bramlette \& Riedel) Gartner, 1970

Lithastrinus grilli Stradner, 1962 (Plate 16, Figures 12-19)

Discoaster hamatus Martini \& Bramlette, 1963

Sphenolithus heteromorphus Deflandre, 1953

Reticulofenestra hillae Bukry \& Percival, 1971

Syracosphaera histrica Kamptner, 1941

Sollasites horticus (Stradner, Adamiker, \& Maresch) Black, 1968

Micrantholithus hoschulzi (Reinhardt) Thierstein, 1971

Parhabdolithus infinitus (Worsley) Thierstein n. comb. (Plate 9, Figures 7-16)

Helicopontosphaera intermedia (Martini) Hay \& Mohler, in Hay et al., 1967

Triquetrorhabdulus inversus Bukry \& Bramlette, 1969

Rucinolithus irregularis Thierstein n. sp. (Plate 2, Figures 10-19)

Helicopontosphaera kamptneri Hay \& Mohler in Hay et al., 1967

Heliolithus kleinpellii Sullivan, 1964

Pseudoemiliania lacunosa (Kamptner) Gartner, 1969

Stephanolithion laffittei Noel, 1957 (Plate 16, Figures 6-11)

Pedinocyclus larvalis (Bukry \& Bramlette) Bukry \& Bramlette, 1971

Broinsonia lata (Noel) Noel, 1970 (Plate 14, Figures 18-21)

Diazomatholithus lehmani Noel, 1965 
TABLE 1 - Continued

Cyclococcolithina leptopora (Murray \& Blackmann) Wilcoxon, 1970 Chiastozygus litterarius (Gorka) Manivit, 1971 (Plate 1, Figures 1-6) Discoaster lodoensis Bramlette \& Riedel, 1954

Cretarhabdus loriei Gartner, 1968

Ellipsolithus macellus (Bramlette \& Sullivan) Sullivan, 1964

Cyclococcolithina macintyrei (Bukry \& Bramlette) Wilcoxon, 1970

Kamptnerius magnificus Deflandre, 1959

Cyclagelosphaera margareli Noel, 1965 (Plate 16, Figures 19-22)

Staurolithites matalosus (Stover) Cepek \& Hay, 1969 (Plate 13, Figures 6-11)

Discoaster mediosus Bramlette \& Sullivan, 1961

Lanternithus minutus Stradner, 1962

Nannoconus minutus Brönnimann, 1955

Reinhardtites mirabilis Perch-Nielsen, 1968

Discoaster mohleri Bukry \& Percival, 1971

Sphenolithus moriformis (Brönnimann \& Stradner) Bramlette \& Wilcoxon, 1967

Pontosphaera multipora (Kamptner) Roth, 1970

Discoaster multiradiatus Bramlette \& Riedel, 1954

Discoaster neohamatus Bukry \& Bramlette, 1969

Discoaster nobilis Martini, 1961

Helicopontosphaera obliqua (Bramlette \& Wilcoxon) n. comb.

Transversopontis obliquipons (Deflandre) Hay, Mohler \& Wade, 1966

Tetralithus obscurus Deflandre, 1959

Micrantholithus obtusus Stradner, 1963

Gephyrocapsa oceanica Kamptner, 1943

Ahmuellerella octoradiata (Gorka) Reinhardt, 1966

Podorhabdus orbiculofenestrus (Gartner) Thierstein, 1971 (Plate 6, Figures 1-7)

Tranolithus orionatus (Reinhardt) Reinhardt, 1966 (Plate 10, Figures 11-15)

Broinsonia orthocancellata Bukry, 1969 (Plate 15, Figures 1-8)

Broinsonia parca (Stradner) Bukry, 1969

Coccolithus pelagicus (Wallich) Schiller, 1930

Manivitella pemmatoidea (Deflandre ex Manivit) Thierstein, 1971 (Plate 11, Figures 6-13)

Discoaster pentaradiatus Tan Sin Hok, 1927

Discoaster perplexus Bramlette \& Riedel, 1954

Zygodiscus plectopons Bramlette \& Sullivan, 1961

Sphenolithus predistentus Bramlette \& Wilcoxon, 1967

Ceratolithus primus Bukry \& Percival, 1971

Rhabdosphaera procera Martini, 1969

Cyclococcolithina protoannula Gartner, 1971

Sphenolithus pseudoradians Bramlette \& Wilcoxon, 1967

Reticulofenestra pseudoumbilica (Gartner) Gartner, 1969

Kamptnerius punctatus Stradner, 1963

Tetralithus pyramidus Gardet, 1955

Discoaster quinqueramus Gartner, 1969

Diadorhombus rectus Worsley, 1971

Isthmolithus recurvus Deflandre in Deflandre \& Fert, 1954

Actinozygus regularis (Gorka) Gartner, 1968

Helicopontosphaera reticulata (Bramlette \& Wilcoxon) Roth, 1970

Reticulofenestra reticulata (Gartner \& Smith) n. comb.

Corollithion rhombicum (Stradner \& Adamiker) Bukry, 1969

Heliolithus riedeli Bramlette \& Sullivan, 1961

Pontosphaera rimosa (Bramlette \& Sullivan) n. comb.

Bidiscus rotatorius Bukry, 1969 (Plate 15, Figures 1-4)

Cretaturbella rothii Thierstein, 1971 (Plate 3, Figures 9, 12-14)

Ceratolithus rugosus Bukry \& Bramlette, 1968

Triquetrorhabdulus rugosus Bramlette \& Wilcoxon, 1967

Discoaster saipanensis Bramlette \& Riedel, 1954

Pontosphaera scutellum Kamptner, 1952

Helicopontosphaera sellii Bukry \& Bramlette, 1969

Helicopontosphaera seminulum (Bramlette \& Sullivan) Hay, 1970

Bramletteius serraculoides Gartner, 1969

Coronocylus serratus Hay, Mohler \& Wade, 1966

Rhabdothorax serratus (Bramlette \& Wilcoxon) Roth, 1970

Umbilicosphaera sibogae (Weber-van Bosse) Gaarder, 1970

Zygodiscus sigmoides Bramlette \& Sullivan, 1961

Broinsonia signata (Noel) Noel, 1970 (Plate 14, Figures 1-5)

Corollithion signum Stradner, 1963
TABLE 1 - Continued

Prediscosphaera spinosa (Bramlette \& Martini) Gartner, 1968

Blackites spinulus (Gartner \& Smith) Roth, 1970

Parhabdolithus splendens (Deflandre) Noel, 1969 (Plate 7, Figures 2-6)

Chiasmolithus solitus (Bramlette \& Sullivan) Locker, 1968

Micula staurophora concava (Stradner) Noel, 1970

Micula staurophora decussata (Vekshina) Noel, 1970

Tegumentum stradneri Thierstein n. sp. (Plate 1, Figures 7-15)

Ericsonia subdisticha (Roth \& Hay) Roth in Baumann \& Roth, 1969

Discoaster surculus Martini \& Bramlette, 1963

Cretarhabdus surirellus (Deflandre) Reinhardt, 1970

Discoaster tamalis Kamptner, 1967

Discoaster tani nodifer Bramlette \& Riedel, 1954

Cruciplacolithus tenuis (Stradner) Hay \& Mohler, 1967

Rhabdosphaera tenuis Bramlette \& Sullivan, 1961

Chiasmolithus titus Gartner, 1970

Eiffellithus trabeculatus (Gorka) Reinhardt \& Gorka, 1967 (Plate

12, Figures 7-18)

Marthasterites tribrachiatus (Bramlette \& Riedel) Deflandre, 1959

Ceratolithus tricorniculatus Gartner, 1967

Sphenolithus tribulosus Roth, 1970

Nannoconus truitti Brönnimann, 1955

Helicopontosphaera truncata (Bramlette \& Wilcoxon) Roth, 1970

Discosphaera tubifera (Murray \& Blackman) Ostenfeld, 1900

Eiffellithus turriseiffeli (Deflandre) Reinhardt, 1965 (Plate 4, Figures 1-6, 9)

Fasciculithes tympaniformis Hay \& Mohler in Hay et al., 1967

Reticulofenestra umbilica (Levin) Martini \& Ritzkowski, 1968

Discoaster variabilis Martini \& Bramlette, 1963

Discoaster woodringi Bramlette \& Riedel, 1954

kamptneri and Umbilicosphaera sibogae are common. Coccolithus pelagicus only occurs in assemblages showing a temperate influence (Site 135, but not Site 142). If only light microscopy is used, the upper boundary of this zone is difficult to draw because of the very small size of Emiliania huxlei, the marker of the next higher zone.

\section{Pseudoemiliania lacunosa Zone}

Pseudoemiliania lacunosa (round and/or elliptical form) is common together with Coccolithus doronicoides, Cyclococcolithina leptopora, Helicopontosphaera kamptneri, $H$. sellii. Few to rare Ceratolithus cristatus, Pontosphaera discopora, P. scutellum, Scyphosphaera sp. and Cyclococcolithina macintyrei also occur. The base of this zone is marked by the disappearance of Discoaster brouweri and a reduction in abundance of Cyclococcolithina macintyrei.

Pliocene

\section{Discoaster brouweri Zone}

Abundant thin-rayed discoasters (Discoaster brouweri, D. pentaradiatus) occur in this interval together with Cyclococcolithina macintyrei, C. leptopora, Helicopontosphaera sellii, $H$. kamptneri and Ceratolithus robustus. The base of this zone is characterized by the last occurrence of Reticulofenestra pseudoumbilica and Sphenolithus abies.

\section{Cyclococcolithus macintyrei Subzone}

Discoaster brouweri is the only species of Discoaster present. Three-, five- and six-rayed forms are common. The base of this subzone is marked by the disappearance of Discoaster pentaradiatus and $D$. surculus. 
TABLE 2

Zonal Assignment and Age of Tertiary Cores Based on Nannofossils

\begin{tabular}{|c|c|c|c|c|c|c|c|c|c|c|c|}
\hline \multirow[b]{2}{*}{ Age } & & \multirow[b]{2}{*}{ Zone } & \multicolumn{9}{|c|}{ Sites } \\
\hline & & & 135 & 136 & 139 & 140 & 141 & 142 & 144 & $144 \mathrm{~A}$ & $144 B$ \\
\hline Pleistocene & $\begin{array}{l}\mathrm{L} \\
\mathrm{E}\end{array}$ & $\begin{array}{l}\text { Gephyrocapsa oceanica } \\
\text { Pseudoemiliania lacunosa }\end{array}$ & 1 & & & & 1 & $\begin{array}{c}1 \\
2,3\end{array}$ & & & \\
\hline Pliocene & L & $\begin{array}{l}\text { Discoaster brouweri } \\
\text { Reticulofenestra pseudoumbilica } \\
\text { Ceratolithus rugosus } \\
\text { Ceratolithus tricorniculatus }\end{array}$ & 2 & 1 & $\begin{array}{l}1 \\
2\end{array}$ & 1 & $\begin{array}{c}2-4 \\
5 \\
5 \\
6\end{array}$ & $\begin{array}{c}4,5 \\
6\end{array}$ & & & \\
\hline Miocene & L & $\begin{array}{l}\text { Discoaster quinqueramus } \\
\text { Discoaster neohamatus } \\
\text { Discoaster hamatus } \\
\text { Catinaster coalitus } \\
\text { Discoaster kugleri } \\
\text { Discoaster exilis } \\
\text { Sphenolithus heteromorphus } \\
\text { Helicopontosphaera ampliaperta } \\
\text { Sphenolithus belemnos } \\
\text { Discoaster druggi } \\
\text { Triquetrorhabdulus carinatus }\end{array}$ & $\begin{array}{l}\text { SW1 } \\
\text { SW2 }\end{array}$ & $\begin{array}{l}2 \\
3 \\
3 \\
4\end{array}$ & $\begin{array}{l}\frac{3,4}{1} \\
5 \\
\downarrow \\
7\end{array}$ & 2 & 7 & 8,9 & & A-1 & \\
\hline Oligocene & $\mathrm{L}$ & $\begin{array}{l}\text { Sphenolithus ciperoensis } \\
\text { Sphenolithus distentus } \\
\text { Sphenolithus predistentus } \\
\text { Helicopontosphaera reticulata } \\
\text { Ericsonia subdisticha }\end{array}$ & & & & & & & & $\begin{array}{l}\text { A-1 } \\
\text { A-1 } \\
\text { A-2 }\end{array}$ & $\begin{array}{l}\text { B-1, } \\
\text { B-2 } \\
\text { B-3 }\end{array}$ \\
\hline Eocene & $\frac{\mathrm{L}}{\mathrm{M}}$ & $\begin{array}{l}\text { Discoaster barbadiensis } \\
\text { Reticulofenestra umbilica } \\
\text { Nannotetrina fulgens } \\
\text { Discoaster sublodoensis } \\
\text { Discoaster lodoensis } \\
\text { Marthasterites tribrachiatus } \\
\text { Discoaster diastypus }\end{array}$ & 5 & & & & & & 1 & A-2 & \\
\hline Paleocene & L & $\begin{array}{l}\text { Discoaster multiradiatus } \\
\text { Discoaster mohleri } \\
\text { Heliolithus kleinpellii } \\
\text { Fasciculithus tympaniformis } \\
\text { Cruciplacolithus tenuis }\end{array}$ & & & & & & & 2 & $\begin{array}{l}\text { A-3 } \\
\text { A-3 } \\
\text { A-3 }\end{array}$ & \\
\hline
\end{tabular}

TABLE 3

Zonal Assignment and Age of Cretaceous Cores Based on Nannofossils

\begin{tabular}{|c|c|c|c|c|c|c|c|}
\hline \multirow[b]{2}{*}{ Zones } & \multirow[b]{2}{*}{ Stages } & \multicolumn{6}{|c|}{ Sites and Cores } \\
\hline & & 135 & 136 & 137 & 143 & 144 & $144 \mathrm{~A}$ \\
\hline \multirow[t]{2}{*}{$\begin{array}{l}\text { Tetralithus } \\
\text { gothicus } \\
\text { trifidus }\end{array}$} & Paleocene & 6 & & & & & $-3 \sim$ \\
\hline & & 7 & & & & 3 & \\
\hline \multirow[t]{2}{*}{$\begin{array}{l}\text { Eiffelithus } \\
\text { augustus }\end{array}$} & Campanian & & 6 & & & & \\
\hline & $\begin{array}{l}\text { Santonian } \\
\text { Coniacian }\end{array}$ & & & & & & $\begin{array}{l}5 \\
6\end{array}$ \\
\hline $\begin{array}{l}\text { Chiastozygus } \\
\text { cuneatus }\end{array}$ & Cenomanian & & & \begin{tabular}{|r|}
7 \\
8 \\
9 \\
10 \\
11 \\
12 \\
13 \\
14 \\
15 \\
\end{tabular} & & 4 & \\
\hline $\begin{array}{l}\text { Eiffellithus } \\
\text { turriseiffeli }\end{array}$ & \multirow{2}{*}{ Albian } & & & -10 & & & \\
\hline $\begin{array}{l}\text { Prediscosphaera } \\
\text { cretacea }\end{array}$ & & & & & & & \\
\hline $\begin{array}{l}\text { Parhabdolithus } \\
\text { angustus }\end{array}$ & \multirow{2}{*}{ Aptian } & & 8 & & BS & $\begin{array}{l}5 \\
6 \\
7 \\
8\end{array}$ & \\
\hline $\begin{array}{l}\text { Chiastozygus } \\
\text { litterarius }\end{array}$ & & 9 & & & & & \\
\hline
\end{tabular}




\section{Discoaster pentaradiatus Subzone}

Discoaster brouweri, D. pentaradiatus and D. surculus occur together. The base of this zone is marked by the highest occurrence of common Discoaster tamalis ("fourrayed $D$. brouweri").

\section{Discoaster tamalis Subzone}

This subzone was proposed by D. Bukry (personal communication, 1971) for the lowermost part of the Discoaster brouweri Zone. Discoaster tamalis is fairly common together with $D$. brouweri (mainly five- and six-rayed), $D$. pentaradiatus and $D$. surculus. $D$. asymmetricus is present in the lower part of this subzone, but it is never common. The base of this subzone coincides with the base of the Discoaster brouweri Zone.

\section{Reticulofenestra pseudoumbilica Zone}

Reticulofenestra pseudoumbilica, Sphenolithus abies, Discoaster brouweri, D. pentaradiatus, D. surculus, D. asymmetricus, D. variabilis and Ceratolithus rugosus are characteristic of this zone. The base is defined by the highest occurrence of Ceratolithus tricorniculatus. Pseudoemiliania lacunosa has not been observed below this zone.

\section{Ceratolithus rugosus Zone}

This zone is not very well defined. The overlap of the range of Ceratolithus tricorniculatus and $C$. rugosus, and the absence of Discoaster quinqueramus and Triquetrorhabdulus rugosus are characteristic.

\section{Ceratolithus tricorniculatus Zone}

The base of this zone is marked by the first occurrence of Ceratolithus tricorniculatus and a reduction in abundance of Discoaster quinqueramus. Common species of this zone are Discoaster brouweri, $D$. surculus, D. pentaradiatus, D. variabilis, D. challengeri, Reticulofenestra pseudoumbilica, Cyclococcolithina macintyrei and Triquetrorhabdulus rugosus. Discoaster quinqueramus is usually present but not abundant. Ceratolithus amplificus occurs near the top of the zone and Ceratolithus primus near the base.

\section{Miocene}

\section{Discoaster quinqueramus Zone}

The earliest occurrence of Discoaster quinqueramus, an increase in abundance of Discoaster berggreni, and a reduction in abundance of $D$. neohamatus mark the base of this zone. Discoaster brouweri, D. quinqueramus, $D$. berggreni and Discoaster variabilis are the dominant species of this zone.

\section{Discoaster neohamatus Zone}

The base of this zone is defined by the disappearance of Discoaster hamatus and an increase in abundance of $D$. neohamatus and $D$. calcaris. Typical for this zone are Discoaster neohamatus, D. calcaris, D. variabilis, D. challengeri, $D$. berggreni and $D$. brouweri.

\section{Discoaster hamatus Zone}

Only one core with strongly etched assemblages was assigned to this zone. The assemblage includes Discoaster hamatus, D. neohamatus, D. bollii, D. variabilis, D. calcaris, D. brouweri (with straight arms).

\section{Catinaster coalitus Zone}

Not encountered.

\section{Discoaster kugleri Zone}

The base of this zone is marked by the earliest occurrence of Discoaster kugleri, the top by the earliest occurrence of Catinaster coalitus. Assemblages belonging to this zone include Discoaster kugleri, D. exilis, D. variabilis, D. deflandrei, Coccolithus eopelagicus and Reticulofenestra pseudoumbilica.

\section{Discoaster exilis Zone}

Not encountered.

\section{Sphenolithus heteromorphus Zone}

Sphenolithus heteromorphus disappears at the top of this zone. Discoaster exilis, $D$. divaricatus, $D$. deflandrei and D. variabilis are common. The ranges of Cyclococcolithina leptopora and $C$. floridana overlap in this zone. The base of the zone is at the level of extinction of Helicopontosphaera ampliaperta and the first occurrence of Discoaster exilis.

\section{Helicopontosphaera ampliaperta Zone}

Strongly etched assemblages recovered from Hole 140 are assigned to this zone; they contain Helicopontosphaera ampliaperta, $H$. kamptneri, $H$. obliqua, Sphenolithus heteromorphus, Reticulofenestra pseudoumbilica, and in the lowermost part some Sphenolithus belemnos.

\section{Sphenolithus belemnos Zone}

In Hole 136, the assemblages recovered from this zone show strong signs of calcite solution. They include Sphenolithus belemnos, Coccolithus eopelagicus, Cyclococcolithina floridana, Discoaster divaricatus, D. deflandrei and Triquetrorhabdulus carinatus.

\section{Discoaster druggii Zone}

This zone is only represented by very poor assemblages which contain Discoaster druggii, D. divaricatus, $D$. deflandrei, Coccolithus eopelagicus, Cyclococcolithina floridana, and Triquetrorhabdulus tricarinatus. The first occurrence of Discoaster druggii marks the base of this zone.

\section{Triquetrorhabdulus carinatus Zone}

Assemblages strongly affected by solution were recovered in Holes 135, 136 and 139. Triquetrorhabdulus carinatus, Coccolithus eopelagicus, Cyclococcolithina floridana, Reticulofenestra abisecta and rare, small Sphenolithus belemnos are typical species in this zone.

\section{Oligocene}

Sphenolithus ciperoensis Zone; Sphenolithus distentus Zone

Not recovered.

\section{Sphenolithus predistentus Zone}

Sphenolithus predistentus is the dominating sphenolith. Rare specimens of Sphenolithus distentus and $S$. capricornutus occur. Reticulofenestra hillae is fairly common in 
the lower part of the zone. The last occurrence of Reticulofenestra umbilica and Helicopontosphaera reticulata and the first occurrence of Sphenolithus distentus mark the base of this zone.

\section{Helicopontosphaera reticulata Zone}

The base of the zone is marked by the last occurrence of Cyclococcolithina formosa. Lanternithus minutus and Isthmolithus recurvus are restricted to the lower part of this zone; they are absent from open ocean assemblages. Common species are Helicopontosphaera reticulata, $H$. intermedia, Reticulofenestra umbilica, $R$. hillae, $R$. bisecta, Sphenolithus predistentus and Ericsonia subdisticha.

\section{Ericsonia subdisticha Zone}

The disappearance of Discoaster saipanensis and $D$. barbadiensis indicate the base of this zone. Assemblages belonging to this zone include Sphenolithus tribulosus, $S$. predistentus, $S$. pseudoradians, Ericsonia subdisticha, Discoaster tani nodifer, D. deflandrei, Cyclococcolithina formosa, C. floridana, Reticulofenestra umbilica and Bramletteius serraculoides.

\section{Eocene}

Only two zones were recovered from the Eocene: the Middle Eocene Reticulofenestra umbilica Zone and the Lower Eocene Marthasterites tribrachiatus Zone.

\section{Reticulofenestra umbilica Zone}

This interval is delimited by the last occurrence of Chiasmolithus grandis and the lowest occurrence of $C$. oamaruensis at the top of the zone, and by the first occurrence of Reticulofenestra umbilica (large specimen, over 15 microns) and the disappearance of Nannotetrina sp. at the base. Assemblages belonging to this zone contain Reticulofenestra umbilica, $R$. bisecta, Chiasmolithus grandis, Campylosphaera dela, Cyclococcolithina protoannula, Discoaster barbadiensis, $D$. saipanensis, $D$. tani nodifer and $D$. tani tani; restricted to the lower part of the zone are Chiasmolithus expansus and $C$. solitus.

\section{Marthasterites tribrachiatus Zone}

A strongly etched assemblage from this zone was found in Hole 135. Only ortholithids were present. Marthasterites tribrachiatus is the dominant species, with only a few specimens of Discoaster lodoensis, $D$. binodosus, $D$. mediosus and Marthasterites contortus.

\section{Paleocene}

A nearly complete Upper Paleocene section was recovered at Site 144 where it rests unconformably on Lower Maestrichtian.

\section{Discoaster multiradiatus Zone}

Neither the upper nor the lower boundary of this zone was cored. Assemblages contain Discoaster multiradiatus, D. mediosus, Toweius craticulus, Chiasmolithus californicus, C. bidens, Cruciplacolithus eminens, Ellipsolithus macellus, E. distichus, Zygodiscus sigmoides, Z. plectopons and Sphenolithus annarhopus.

\section{Discoaster mohleri Zone}

The upper boundary of this zone was not cored. The base is defined by the first occurrence of Discoaster mohleri, which is the oldest discoaster. The assemblages include Discoaster mohleri, Fasciculithes tympaniformis, Chiasmolithus californicus, $C$. consuetus, Cruciplacolithus tenuis, Zygodiscus plectopons, Z. sigmoides, Ellipsolithus distichus and $E$. macellus.

\section{Heliolithus kleinpellii Zone}

Both Heliolithus kleinpellii and $H$. riedeli were found to occur in the same samples together with Zygodiscus sigmoides, Z. plectopons, Fasciculithus tympaniformis, Chiasmolithus consuetus, $C$. californicus and Cruciplacolithus eminens. It does not seem possible to distinguish the Heliolithus riedeli Zone and the Heliolithus kleinpellii Zone in this section (Hole 144A).

\section{Fasciculithus tympaniformis Zone}

The lowest Tertiary sediments recovered contain Fasciculithus tympaniformis, Toweius craticulatus, Cruciplacolithus eminens, Chiasmolithus consuetus and Zygodiscus plectopons. They are assigned to the Fasciculithus tympaniformis Zone. The base of this zone was not recovered. The top of this zone is marked by the first occurrence of Heliolithus kleinpellii.

\section{CRETACEOUS CALCAREOUS NANNOPLANKTON ZONES}

Calcareous nannoplankton of the Cretaceous have received less attention than Cenozoic nannoplankton. None of the zonal schemes proposed so far have been generally accepted. Cepek and Hay (1969) have presented a zonation for most of the Upper Cretaceous based on sections from Alabama and Kansas. Bukry and Bramlette (1970) introduced four zones for the uppermost part of the Cretaceous. Worsley (1971) subdivided the Lower Cretaceous into six zones based on a study of cores recovered on DSDP Leg 1. Some of the zonal markers used in his zonation are rare-to-absent or difficult to recognize in other sections. Thierstein (1971) introduced a new zonation based on a detailed study of sections from Southeastern France and of cores recovered during DSDP Leg 1. These zones are correlated with zones based on cephalopods, calpionellids and foraminifera.

The zones used in this report were originally proposed by Bukry and Bramlette (1970), Cepek and Hay (1969) and Thierstein (1971).

The highest zones of the Upper Cretaceous, the Tetralithus murus Zone and the Lithrapidites quadratus Zone were not encountered.

\section{Tetralithus gothicus trifidus Zone}

The upper boundary is marked by the earliest occurrence of Lithraphidites quadratus. The base of this zone is defined by the earliest occurrence of Tetralithus gothicus trifidus. Common species are: Tetralithus gothicus gothicus, $T$. gothicus trifidus, Arkhangelskiella cymbiformis, Cribrosphaerella ehrenbergi, Microrhabdulus decoratus, Eiffellithus turriseifeli, Prediscosphaera cretacea.

Age: Early Maestrichtian to Late Campanian. 


\section{Eiffellithus augustus Zone}

The top of the zone is marked by the earliest occurrence of Tetralithus gothicus trifidus and the last occurrence of Eiffelithus augustus. The base of this zone coincides with the earliest occurrence of Broinsonia parca. Species present: Broinsonia parca, Eiffelithus augustus, Cribrosphaerella ehrenbergi, Glaukolithus diplogrammus, Prediscosphaera cretacea. This zone is not very well represented in the recovered cores.

Age: Campanian

\section{Santonian to Coniacian}

Cores 5 and 6 of Hole 144A contain calcareous nannoplankton which cannot be assigned to any of the described zones. Eiffelithus augustus is still present, but Broinsonia parca was not found. Important species are: Eiffelithus augustus, E. turriseiffeli, Cretarhabdus conicus, C. surirellus, Parhabdolithus angustus, Lithastrinus floralis, L. grilli, Macrorhabdulus decoratus, Micula staurophora, Cylindralithus coronatus, Corollithion acutum n. sp.

\section{Chiastozygus cuneatus Zone}

The upper boundary of this zone was not recovered. Cepek and Hay (1969) defined it by the earliest occurrence of Corollithion exiguum. The base of this zone is marked by the earliest occurrence of Chiastozygus cuneatus and Lithraphidites alatus n. sp. Important species include: Chiastozygus cuneatus, Lithraphidites alatus, Parhabdolithus splendens, P. embergeri, Podorhabdus coronadventis, $P$. orbiculofenestrus, Lithastrinus floralis, Corollithion signum, Staurolithites matalosus, and Cribrosphaerella ehrenbergi.

Age: Cenomanian

\section{Eiffelithus turriseiffeli Zone}

The base of this zone is marked by the earliest occurrence of Eiffelithus turriseiffeli and Corollithion signum. Prediscosphaera spinosa and Broinsonia bevieri first appear within this zone, and Braarudosphaera africana disappears within this zone. Important species are: Glaukolithus diplogrammus, Parhabdolithus asper, $P$. splendens, $P$. embergeri, $P$. angustus, Prediscosphaera cretacea, Stephanolithon laffitei, Cretarhabdus surirellus, Chiastozygus litterarius, Lithastrinus floralis, Staurolithites matalosus, Eiffelithus turriseiffeli, E. trabeculatus, Podorhabdus dietzmanni.

Age: Late Albian.

\section{Prediscosphaera cretacea Zone}

The base of this zone is marked by the first occurrence of Prediscosphaera cretacea and Cribrosphaerella ehrenbergi. This zone was not encountered on Leg 14.

Age: Early Albian.

\section{Parhabdolithus angustus Zone}

The base of this zone is defined by the first occurrence of Parhabdolithus angustus, Lithastrinus floralis and the disappearance of Nannoconus wassali and Micrantholithus obtusus. Important species include: Nannoconus bucheri, Cyclagellosphaera margareli, Diazomatholithus lehmanni, Lithastrinus floralis, Corollithion ellipticum, C. achylosum,
Braarudosphaera africana, Staurolithites matalosus, Eiffelithus trabeculatus, Parhabdolithus splendens, $P$. angustus.

Age: Late Aptian.

\section{Chiastozygus litterarius Zone}

The base of this zone is marked by the first occurrence of Chiastozygus litterarius and by the disappearance of Nannoconus colomi and Micrantholithus hoschulzi. Close to the top of the zone Eiffelithus trabeculatus, Corollithion achylosum and Staurolithites matalosus make their first appearance. Important species are: Nannoconus wassali, $N$. bucheri, Cyclagellosphaera margareli, Diazomatholithus lehmani, Micrantholithus obtusus, Parhabdolithus splendens, P. asper, Cretarhabdus surirellus.

Age: Early Aptian.

Correlation of the Lower Cretaceous in the Atlantic (Leg 1 and Leg 14) with the sections in Southern France is good. The assemblages are very similar, and the stratigraphic ranges of the various species are almost identical in the two regions. Note that Core $135-9$ and Core $136-8$ contain some forms which are reworked from the Valanginian to Middle Hauterivian. Details on the nannoplankton distribution in the Lower Cretaceous of Southeastern France and from the Cat Gap Area, NE of the Bahamas (Leg 1, Sites 4 and 5) can be found in Thierstein (1971).

Remarks on The Identification of Some Cretaceous Species in the Light Microscope

Many Cretaceous nannoplankton species are small and structurally very complicated. Specific characters are often only apparent when viewed in the electron microscope. Recent taxonomic studies using electron microscopy have lead to a very fine subdivision of many genera. An investigation of identical specimens in the scanning electron and light microscopes shows that in many cases the light microscope allows only the recognition of species groups which can be subdivided into distinct species in the electron microscope.

The similarity of some of the species of Broinsonia in the light microscope is clearly demonstrated on Plates 13 to 15. The following three species groups are used on the range charts because only selected samples could be studied in the electron microscope and it was impossible to determine the individual species in the light microscope with certainty.

Species group 1

Prediscosphaera cretacea cretacea (Arkhangelski) Bukry + Prediscosphaera cretacea ponticula Bukry

Species group 2

Staurolithites matalosus (Stover) Cepek \& Hay + Broinsonia signata (Noel) Noel + Broinsonia dentata Bukry

Species group 3

Broinsonia bevieri Bukry + Broinsonia lata (Noel) Noel + Broinsonia orthocancellata Bukry

\section{CALCAREOUS NANNOPLANKTON AT THE DRILL SITES}

Calcareous nannofossil assemblages and zonal assignment of the cores is discussed below. For additional information on the distribution of species refer to the detailed range 
charts for each site. (Tables 4 to 15). Remarks on the preservation of nannofossils follow in the next chapter.

\section{Site 135 (lat $35^{\circ} 20.80^{\prime} \mathrm{N}$, long $10^{\circ} 25.46^{\prime} \mathrm{W}$, water depth 4152 meters)}

Site 135 was drilled on a topographic high 35 kilometers southeast of the Horseshoe Abyssal Plain. The upper 325 meters (Cores 1 through 4 ) consist of nannoplankton chalk ooze. Core 1 ( 0 to 4 meters) contains rich assemblages belonging to the Pleistocene Gephyrocapsa oceanica Zone. Core 2 ( 80 to 89 meters) recovered the Lower Pliocene Ceratolithus rugosus Zone with common Ceratolithus rugosus and C. tricorniculatus. Core 3 (173 to 182 meters) is assigned to the Upper Miocene Discoaster neohamatus Zone; it yields common Discoaster neohamatus, D. calcaris, D. brouweri and D. variabilis. Core 4 (259 to 262 meters) contains poorly preserved assemblages with Sphenolithus heteromorphus, Discoaster exilis and $D$. deflandrei. It belongs to the Middle Miocene Sphenolithus heteromorphus Zone. The two sidewall cores (SW1 at 315 meters and SW2 at 325 meters) both contain poor assemblages which are characteristic of the Triquetrorhabdulus carinatus Zone of Early Miocene to Late Oligocene age. Nannoplankton are less abundant in the lower lithologic unit, which consists of silty and sandy muds.

The core catcher of Core 5 ( 335 to 341 meters) contains common Marthasterites tribrachiatus together with a few specimens of Discoaster lodoensis and Marthasterites contortus. This assemblage is slightly heterogeneous but the flood of Marthasterites tribrachiatus indicates that it is best assigned to the Marthasterites tribrachiatus Zone of Early Eocene age. Core 6 (341 to 350 meters) and Core 7 (431 to 435 meters) contain a very poor Lower Maestrichtian to Upper Campanian nannoflora (probably Tetralithus gothicus trifidus Zone). The black and green shales recovered from Core 8 (564 to 569 meters) lack nannoplankton. Core 9 (685 to 687 meters) consists of nannoplankton marls with abundant nannoplankton. The occurrence of Chiastozygus litterarius, Nannoconus bucheri, N. colomi, Cyclagelosphaera margareli and the absence of Parhabdolithus angustus and Corollithion ellipticum are indicative of the Lower Aptian Chiastozygus litterarius Zone. Some reworked forms from the Valanginian to Middle Hauterivian for example Cruciellipsis cuvillieri and Diadorhombus rectus, occur rarely in this core.

\section{Site 136 (lat $34^{\circ} 10.13^{\prime} \mathrm{N}$ long $16^{\circ} 18.19^{\prime} \mathrm{W}$, water depth 4169 meters)}

Site 136 lies 160 kilometers north of Madeira in an area of abyssal hills. The upper 244 meters (Cores 1 through 3 ) consist of nannoplankton chalk ooze. Core 1 (130 to 139 meters) recovered the Lower Pliocene Ceratolithus tricorniculatus Zone with Ceratolithus tricorniculatus, C. primus, Triquetrorhabdulus rugosus and rare Discoaster quinqueramus (in the lowermost part only). Core 2 (216 to 225 meters) yields assemblages including Sphenolithus heteromorphus, Discoaster exilis and $D$. deflandrei which are assigned to the Middle Miocene Sphenolithus heteromorphus Zone. The silty clays of Core 3 (lower part) through Core 5 are generally poorer in nannoplankton than the oozes above. Core 3 ( 235 to 244 meters) contains poor nannofloras which include Sphenolithus belemnos, Discoaster deflandrei and Cyclococcolithina floridana in the upper part (Sphenolithus belemnos Zone) and rare Discoaster druggii, Triquetrorhabdulus carinatus and Reticulofenestra abisecta (indicative of the Discoaster druggii Zone) in the lower part. Core 4 (244 to 253 meters) yields rare Triquetrorhabdulus carinatus, Reticulofenestra abisecta and Discoaster deflandrei and therefore belongs to the Triquetrorhabdulus carinatus Zone (Lower Miocene).

The silty clays with ash beds and banded-colored clays recovered in Cores 5 through 8 are poor in nannoplankton. Core 5 ( 253 to 262 meters) is barren of coccoliths except for the core catcher which contains a poor Coniacian to Santonian assemblage with Marthasterites $\mathrm{cf}$. furcatus. Core 6 (262 to 271 meters) is richer in nannofossils. Eiffelithus augustus and Microrhabdulus decoratus indicate a Campanian age (Eiffelithus augustus Zone?). Core 7 (271 to 280 meters) is barren of nannofossils. The nannofossil marls recovered in Core 8 ( 280 to 289 meters) and from chips out of the bumper sub contain rich assemblages typical of the Parhabdulithus angustus Zone (Lower Aptian) including Parhabdolithus angustus, Nannoconus truitti, N. bucheri (only in the bumper sub), Podorhabdus coronadventis, Corollithion achylosum and Diazomatholithus lehmani. Some species reworked from the Valanginian to Middle Hauterivian especially Cruciellipsis cuvillieri and Diadorhombus rectus occur in some samples.

Site 137 (lat $25^{\circ} 55.53^{\prime} \mathrm{N}$., long $27^{\circ} 03.64^{\prime}$ W., water depth 5361 meters)

Site 137 lies about 1000 kilometers west of Cap Blanc in an area of abyssal hills close to the foot of the continental rise. The zeolitic brown clays recovered in the first six cores ( 0 to 225 meters) are barren of nannofossils. Cores 7 through 16 consist of a varicolored nannoplankton marl which yields very rich coccolith assemblages. Cores 7 (256 to 265 meters) through 15 (348 to 357 meters) and Section 1 of Core 16 all contain remarkably similar assemblages and belong to the Cenomanian Chiastozygus cuneatus Zone. Important species are the following: Chiastozygus cuneatus, Cretarhabdus coronadventis, Prediscosphaera cretacea, Lithraphidites alatus, Corollithion exiguum, Lithastrinus floralis and Eiffellithus turriseiffeli. Sections 2 through 4 of Core 16 ( 375 to 382 meters) and the sidewall Core SW1 (393 meters) yield similar assemblages with Eiffellithus turriseiffeli but lack Chiastozygus cuneatus and Lithraphidites alatus and are thus assigned to the Upper Albian Eiffelithus turriseiffeli Zone.

Site 138 (lat $25^{\circ} 55.37^{\prime} \mathrm{N}$., long $25^{\circ} 33.79^{\prime} \mathrm{W}$., water depth 5288 meters)

Site 138 is located 130 kilometers east of Site 137 and about 850 kilometers west of Cap Blanc at the foot of the Continental rise. The clays, silts and sands recovered in the six cores are barren of calcareous nannofossils except for very rare Watznaueria barnesae, Cretarhabdus surirellus and Eiffelithus turriseiffeli in Core 5 (332 to 341 meters) indicating a Late Cretaceous age. 
Site 139 (lat $23^{\circ} 31.14^{\prime} \mathrm{N}$., long $18^{\circ} 42.26^{\prime} \mathrm{W}$., water depth 3047 meters)

Site 139 was drilled on the middle of the continental rise about 250 kilometers northwest of Cap Blanc. The upper 400 meters (Cores 1 through 4) consist of nannoplankton ooze. Core 1 (114 to 123 meters) recovered the Lower Pliocene Reticulofenestra pseudoumbilica Zone with common Reticulofenestra pseudoumbilica, Coccolithus pelagicus, Discoaster asymmetricus, $D$. brouweri, $D$. surculus and $D$. pentaradiatus. Core 2 (225 to 234 meters) belongs to the Lower Pliocene Ceratolithus tricorniculatus Zone; it contains Ceratolithus tricorniculatus, Triquetrorhabdulus rugosus, Discoaster variabilis, $D$. surculus and rare D. quinqueramus. Cores 3 (345 to 354 meters) and 4 (455 to 463 meters) yield very similar assemblages with Discoaster kugleri, D. exilis, D. deflandrei and Coccolithus eopelagicus; they are assigned to the Discoaster kugleri Zone (Middle Miocene). This great thickness of about 200 meters for a zone which is known to be of a short duration is unusual and it might be due to slumping.

The lower part of the section drilled at this site (from 525 to 665 meters) consists of diatom ooze. Sidwall Core 1 (530 meters) and Core 5 (570 to 576 meters) contain very poor assemblages including Discoaster deflandrei, $D$. divaricatus, rare Triquetrorhabdous carinatus and Reticulofenestra pseudoumbilica which cannot be assigned to any zone with certainty but indicate a Middle to Early Miocene age. Core 6 (607 to 612 meters) lacks nannoplankton, and Core 7 (656 to 665 meters) yields very poor assemblages indicative of the Triquetrorhabdulus carinatus Zone (Lower Miocene).

\section{Site 140 (lat $21^{\circ} 44.97^{\prime} \mathrm{N}$., long $21^{\circ} 47.52^{\prime} \mathrm{W}$, water depth} 4483 meters)

Site 140 is situated about 450 kilometers west of Cap Blanc at the foot of the continental rise. The uppermost 120 meters consist of white nannoplankton ooze. Core 1 (89 to 98 meters) contains common Discoaster tamalis, $D$. pentaradiatus, D. brouweri, D. surculus and Reticulofenestra aff. $R$. pseudoumbilica (much smaller, with a faint rim); it is assigned to the Discoaster tamalis Subzone of the Discoaster brouweri Zone (Upper Pliocene). The next lower lithologic unit consists of clays, silts and diatom oozes with poor nannoplankton assemblages. Core 1 of Hole 140A (150 to 159 meters) yields poor and heterogeneous assemblages with Discoaster exilis, $D$. brouweri and $D$. pentaradiatus indicating a Middle to Late Miocene age. Core 2 (201 to 210 meters) recovered sediments of the Helicopontosphaera ampliaperta Zone (Lower Miocene) with Helicopontosphaera ampliaperta, Discoaster deflandrei, Sphenolithus heteromorphus, S. belemnos, and Triquetrorhabdulus carinatus (small specimens in the lowermost part only). The diatom muds and silty clays in the lower part of this hole (235 to 651 meters) lack calcareous nannoplankton.

\section{Site 141 (lat $19^{\circ} 25.16^{\prime} \mathrm{N}$., long $23^{\circ} 59.91^{\prime}$ W., water depth 4148 meters)}

Site 141 is located on a piercement structure in the lower continental rise 200 kilometers north of Cape Verde Islands. Foraminiferal nannoplankton ooze was recovered in the uppermost 80 meters overlying zeolitic clay ( 83 to 295 meters) which is barren of calcareous fossils and rests on basalt. An excellent Quaternary to Pliocene section was cored almost continuously. Core 1 ( 5 to 14 meters) belongs to the Lower Pleistocene Pseudoemiliania lacunosa Zone. Both circular and elliptical Pseudoemiliania lacunosa, Coccolithus doronicoides, C. pelagicus, Cyclococcolithina leptopora and Helicopontosphaera kamptneri are the dominant species. The uppermost section of Core 2 (14 to 23 meters) still belongs to the same zone. Sections 2 through 5 of Core 2 contain common Discoaster brouweri and Cyclococcolithina macintyrei and are thus assigned to the Cyclococcolithina macintyrei Subzone of the Discoaster brouweri Zone. Section 6 of Core 2 and Core 3 (23 to 32 meters) yield similar assemblages with the addition of Discoaster pentaradiatus Subzone of the Discoaster brouweri Zone. Discoaster tamalis is common in Core 4 (32 to 41 meters) and in the upper part of Section 1 of Core 5 (41 to 50 meters) indicating the Discoaster tamalis Subzone of the Discoaster brouweri Zone.

The lower part of Section 1, and Sections 2 through 4 of Core 5 recovered the Reticulofenestra pseudoumbilica Zone with common Reticulofenestra pseudoumbilica and Discoaster asymmetricus. An overlap of the ranges of Ceratolithus rugosus and C. tricorniculatus is observed in the lower part of Core 5; this is indicative of the Ceratolithus rugosus Zone of Early Pliocene age. After a drilled interval of nine meters, Core 6 (59 to 68 meters) recovered assemblages typical of the Lower Pliocene Ceratolithus tricorniculatus Zone with Ceratolithus tricorniculatus, $C$. amplificus, Triquetrorhabdulus rugosus and rare Discoaster quinqueramus. In Core 7 ( 79 to 88 meters) the transition from calcareous ooze to barren brown clay occurs. Sections 1 through 3 contain rare Discoaster hamatus common $D$. neohamatus, $D$. calcaris, $D$. quinqueramus, $D$. brouweri and $D$. pentaradiatus, and they are assigned to the Discoaster hamatus Zone (Middle Miocene). Sections 4 through 6 of Core 7 and Cores 8 and 9 are barren of nannofossils.

Site 142 (lat $3^{\circ} 22.15^{\prime} \mathrm{N}$., long $42^{\circ} 23.49^{\prime} \mathrm{W}$., water depth 4372 meters)

Site 142 lies in the Cera Abyssal Plain south of the Cera Rise about 650 kilometers north of the Amazon River. The sediments recovered from the uppermost part of the hole $(0$ to 350 meters) consist of calcareous muds, nannoplankton marl oozes and interbedded sands. Core 1 (98 to 106 meters) contains common nannoplankton in the fine: grained layers. Gephyrocapsa oceanica is abundant in all the samples indicating that this core belongs to the Pleistocene Gephyrocapsa oceanica Zone. Coccolithus pelagicus is entirely missing from the Pleistocene through Upper Miocene at this site which indicates higher water temperatures than at the eastern Atlantic sites during the Late Cenozoic.

Cores 2 (200 to 209 meters) and 3 (293 to 301 meters) belongs to the Pseudoemiliania lacunosa Zone (Lower Pleistocene); they contain common Pseudoemiliania lacunosa, Coccolithus doronicoides and Cyclococcolithina leptopora. The middle lithologic unit (350 to 560 meters) consists of nannoplankton marls and foraminiferal calcarenites. Cores 4 (367 to 376 meters) and 5 (423 to 429) 
contain common Reticulofenestra pseudoumbilica and rare Discoaster asymmetricus and are therefore assigned to the Reticulofenestra pseudoumbilica Zone. Core 6 (451 to 457 meters) recovered the Lower Pliocene Ceratolithus tricorniculatus Zone containing Ceratolithus tricorniculatus and rare $C$. amplificus.

Core 7 (479 to 487 meters) yields assemblages including Discoaster quinqueramus, $D$. berggrenii and rare Triquetrorhabdulus rugosus; it belongs to the lower part of the Discoaster quinqueramus Zone, (Upper Miocene). The upper part of Core 8 (529 to 538 meters) is assigned to the Upper Miocene Discoaster neohamatus Zone with assemblages including Discoaster neohamatus, D. calcaris and $D$. variabilis. Gray nannofossil marls considered to belong to the rise sediments were recovered in the core catcher of Core 8 and in Core 9 ( 575 to 581 meters). They contain assemblages with Sphenolithus heteromorphus, Discoaster exilis and $D$. deflandrei which are typical of the Middle Miocene Sphenolithus heteromorphus Zone.

Site 143 (lat $9^{\circ} 28.45^{\prime} \mathrm{N}$., long $54^{\circ} 23.49^{\prime}$ W., water depth 3461 meters)

Site 143 lies on the steep lower flank of the Demerara Rise about 270 kilometers north of Surinam. The only core recovered consists of green silts and sandstones with a sparse nannoflora including Podorhabdus dietzmanni, Cretarhabdus coronadventis, Parhabdolithus angustus and Corollithion achylosum. This nannoplankton assemblage is typical of the Upper Aptian Parhabdolithus angustus Zone. Some contamination with Recent material was also observed in that core.

Site 144 (lat $9^{\circ} 27.23^{\prime} \mathrm{N}$., long $54^{\circ} 20.52^{\prime} \mathrm{W}$., water depth 2939 meters)

Site 144 lies near the top of the steep lower flank of the Demarara Rise about 3 kilometers southwest of Site 143. Three holes were drilled at this site: Holes 144, 144A and 144B. The cores from these three holes are discussed in stratigraphical order from top to bottom. The uppermost part of the section at this site ( 0 to 125 meters, Cores $1 \mathrm{~B}$, 2B, 1A, 3B, 2A, 1 and 2) consists of calcareous ooze.

The youngest sediment found at this site was recovered at the top of Core 1A. It is a piece of Upper Miocene ooze resting on Lower Oligocene which is probably due to slumping. It contains an assemblage typical of the Discoaster quinqueramus Zone. Cores $1 \mathrm{~B}$ (0 to 9 meters), 2B (10 to 19 meters) and Section 1 of Core 1A (20 to 29 meters) contain common Sphenolithus predistentus, rare Sphenolithus distentus and Reticulofenestra hillae. This assemblage is typical for the Lower Oligocene Sphenolithus predistentus Zone, although some forms might be reworked from the lowermost Oligocene to Eocene (for example, Reticulofenestra hillae). Sections 3 through 5 of Core $1 \mathrm{~A}$ belong to the Helicopontosphaera reticulata Zone and are characterized by assemblages including Helicopontosphaera reticulata, Reticulofenestra umbilica, rare Lanternithus minutus and Isthmolithus recurvus. In Cores 3B (27 to 36 meters) and 2A (38 to 47 meters) Ericsonia subdisticha is more abundant than above and Cyclococcolithina formosa is present which-in the absence of Eocene discoasters-is indicative of the Early Oligocene Ericsonia subdisticha
Zone. The Lower Oligocene rests unconformably on Middle Eocene. The core catcher of Core 2A (38 to 47 meters) and Core 1 (57 to 65 meters) belong to the Middle Eocene Reticulofenestra umbilica Zone with an assemblage including Discoaster barbadiensis, D. saipanensis, Chiasmolithus grandis, $C$. solitus and Campylosphaera dela. Core 2 (104 to 120 meters) contains Discoaster multiradiatus, D. mediosus, rare Heliolithus kleinpellii, Elipsolithus macellus and Cruciplacolithus eminens. It is assigned to the Upper Paleocene Discoaster multiradiatus Zone.

Between 125 and 180 meters (Cores 3A, 3 and 4A), zeolitic gray marls were cored. Core $3 \mathrm{~A}$ (140 to 149 meters) contains a fairly condensed Upper Paleocene section. Sections 1 through 3 yield Discoaster mohleri, Heliolithus kleinpellii, $H$. riedeli and Fasciculithus tympaniformis, Chiasmolithus californicus and C. consuetus and, thus, are assigned to the Upper Paleocene Fasciculithes tympaniformis Zone. Upper Paleocene lies unconformably on Lower Maestrichtian with a fairly sharp boundary at about 100 centimeters in Section 5 of Core $3 \mathrm{~A}$. The lower part of Core $3 \mathrm{~A}$ and Core $4 \mathrm{~A}$ recovered the Lower Maestrichtian to Upper Campanian Tetralithus gothicus trifidus Zone with assemblages including Tetralithus gothicus trifidus, rare Kamptnerius magnificus and $K$. punctatus.

The sediments cored between 180 and 230 meters (Cores 5A, 6A and 4) are zeolitic black clays and olive marls. Cores 5A (180 to 189 meters) and 6A (189 to 197 meters) contain Eiffelithus augustus, Lithastrinus floralis, Corollithion signum, C. achylosum and rare Marthasterites furcatus which indicate a Santonian to Coniacian age. An assignment to any of the existing zones is not possible. Core 4 contains assemblages typical of the Cenomanian Chiastozygus cuneatus Zone, including: Chiastozygus cuneatus, Eiffelithus turriseiffeli, Lithastrinus floralis, Corollithion achylosum, C. signum and Staurolithites matalosus (group).

Core 5 (264 to 270 meters) recovered olive to gray marl, and Cores 6,7 and 8 quartzose marlstone with shelly limestone. They all contain poor assemblages with Parhabdolithus angustus, Lithastrinus floralis, Cretarhabdus crenulatus, Braarudosphaera bigelowi and rare Nannoconus minutus. These nannofloras are assigned to the Late Aptian Parhabdolithus angustus Zone.

\section{PRESERVATION}

The calcite skeletons of calcareous nannoplankton are affected by solution and secondary calcite overgrowth. Calcareous nannoplankton are more resistant to solution than planktonic foraminifera probably because of an organic coating which protects coccoliths. Solution is species preferential and therefore alters the composition of an assemblage.

Holococcoliths are least resistant and are usually absent from most deep-sea sediments. Rhabdosphaera, Pontosphaera and Scyphosphaera are among the least resistant genera found in open-ocean sediments. Reticulofenesta, Chiasmolithus, Helicopontosphaera and Sphenolithus are intermediate in resistance to solution. Cyclococcolithina and Coccolithus are the most resistant helioliths. Their strongly imbricate distal shield resists solution better than their proximal shield. Discoasters are the most resistant 
group of calcareous nannofossils. An increase in solution leads to an enrichment in discoasters, as can be seen in the following lists of the relative abundance of nannofossils from Hole 135 .

\section{5-3-1, slightly etched (E-1):}

$5 \%$ Discoaster

30\% Reticulofenestra pseudoumbilica

$10 \%$ Cyclococcolithina leptopora and C. macintyrei

$45 \%$ Coccolithus doronicoides

$5 \%$ Coccolithus pelagicus

5\% Others (Helicopontosphaera, Triquetrorhabdulus rugosus etc.)

135-4-1, slightly etched (E-1):

$5 \%$ Discoaster

$20 \%$ Cyclococcolithina floridana

$20 \%$ Coccolithus pelagicus

$50 \%$ Reticulofenestra pseudoumbilica (small)

5\% Others (Helicopontosphaera, Sphenolithus, etc.)

135-4-Core Catcher, moderately etched (E-2):

$30 \%$ Discoaster

45\% Cyclococcolithina floridana

$45 \%$ Coccolithus pelagicus

$10 \%$ Reticulofenestra pseudoumbilica

135-Sidewall Core 1, strongly etched (E-3):

$50 \%$ Coccolithus and Cyclococcolithina

50\% Discoaster

Core 7 of Hole 141 recovered the transition of calcareous ooze to barren brown clay. Samples from the upper two sections contain mostly discoasters and a few isolated shields of Coccolithus pelagicus, Reticulofenestra pseudoumbilica and Cyclococcolithina macintyrei. The assemblages in Section 3 consist only of Discoaster.

The first signs of etching are usually slightly serrate margins of placoliths. More strongly etched samples show an increasing number of isolated shields usually with enlarged central pores. Shields consisting of strongly imbricate elements are more resistant than shields with nonoverlapping elements. Central cross structures and central grilles of coccoliths are easily dissolved. Discoasters lose the delicate bifurcating branches and knobs at the ray tips and are also attacked from the center. Delicate thin-rayed discoasters with a small central area tend to break up into isolated arms. More robust discoasters often show a central pore in strongly etched assemblages.

Secondary calcite overgrowth affects discoasters more strongly than coccoliths. Placoliths often show a small secondary enlargement of some elements giving them an irregular appearance. Their general outline is usually preserved and coccoliths can still be identified when discoasters are so strongly overgrown that the original species can no longer be recognized. Central cross-structures in Chiasmolithus tend to become wider and finally coalesce and cover up the whole central area. The arms of discoasters increase in thickness and any ornamentation is covered up by secondary calcite. The next step is a gradual filling of the interray area, leading to discoasters with a large and usually thick central area and a short free length of the arms. The arms can coalesce almost completely and are separated only by prominent sutures. Many so-called species of the Discoaster deflandrei group are just different stages of overgrowth. Strongly overgrown specimens of the Discoaster deflandrei group resemble overgrown specimens of the Discoaster tani group.

The degree of overgrowth depends on the lithology and on the depth of burial. Nannofossils from permeable sediments low in clay content (calcareous ooze, chalk, limestone) usually show considerably more overgrowth than nannofossil from marls. For instance, the nannoplankton from the Cretaceous marls at Sites 135 and 137 are very well preserved and show hardly any sign of overgrowth, whereas assemblages from Cretaceous calcareous ooze from the central Pacific show considerable overgrowth. The degree of overgrowth in a sediment of a certain type depends on the depth of burial. Nannoplankton assemblages recovered from calcareous ooze at a depth of less than 150 meters subbottom show hardly any signs of overgrowth, but most assemblages from below 150 to 200 meters show overgrowths.

The degree of overgrowth does not seem to depend on the age of the sediments. Assemblages as old as Early Cretaceous are often perfectly preserved. In some sediments etching and overgrowth is observed in the same sample. The coccoliths show serrate margins and other signs of etching, whereas the arms of the discoasters are overgrown with secondary calcite. The nannoplankton was probably etched while it was exposed to the bottom waters and secondary calcite was precipitated in the sediment at a later time.

An attempt was made to express the degree of etching and overgrowth by using seven categories of preservation. All observations were made with the light microscope. A more detailed scale should be established, once the original composition of unaffected assemblages is better known for assemblages of different age.

The following categories of preservation were used on the range charts (Tables 4 to 15 ):

G: Excellent preservation, no signs of etching or overgrowth.

Etching: E-1: Slight etching, delicate features destroyed. Coccoliths show serrate outlines. Very few isolated shields. Central cross-structures usually preserved. Pontosphaera, Rhabdosphaera, Scyphosphaera and other less solution resistant species preserved.

E-2: More delicate species dissolved. Delicate central structures (cross, grille) destroyed. Helicopontosphaera, Sphenolithus usually preserved but other more delicate genera (Pontosphaera, Rhabdosphaera) absent. Some isolated shields. Relative abundance of discoaster increased up to 20 to 30 percent.

E-3: Only solution-resistant species left. Coccoliths mostly as isolated shields. Discoaster dominant with $\mathrm{Coc}$ colithus, Cyclococcolithina, sometimes Reticulofenestra in smaller numbers.

\section{Overgrowth}

0-1: Slight thickening of the arms of discoasters. Some elements of coccoliths tend to grow. Central structures in 
coccoliths usually affected (thickening of crossbars in Chiasmolithus).

0-2: Arms of discoasters strongly thickened. Delicate central structures of coccoliths and ornamentation of discoasters completely obscured.

0-3: Discoasters show much overgrowth. Original species often not recognizable (calcified specimens often assigned to artificial species). Delicate coccoliths are covered with so much calcite that identification is difficult. This degree of overgrowth is usually only found in lithified sediments.

\section{REMARKS ON PALEOECOLOGY}

Coccoliths are good paleotemperature indicators as demonstrated by McIntyre (1967) and McIntrye and Bé (1967) for the Recent and Pleistocene. Very little is known about the temperature ranges of Tertiary nannoplankton.

Coccolithus pelagicus, now living only in cool subarctic waters of $9-14^{\circ} \mathrm{C}$, occurs in the Pleistocene to Miocene of all the Eastern Atlantic sites where nannoplankton-bearing sediments of that age were recovered. This species is absent from the western Atlantic Site 142, which lies at a latitude of $3^{\circ} \mathrm{N}$. This suggests fairly cool water temperatures for the eastern Atlantic in the Late Cenozoic (Miocene to Pleistocene).

Temperatures of $9-14^{\circ}$ at a latitude of $19^{\circ} \mathrm{N}$ (Site 141) during the Late Neogene may be somewhat low. Martini and Worsley (1971) report common Coccolithus pelagicus from the tropical west Pacific at a latitude of $2^{\circ} \mathrm{N}$ (Site 62 of Leg 7), and consider it an indication of a Late Pliocene cooling. The Coccolithus pelagicus group is heterogeneous. Eocene and Oligocene forms often assigned by some authors to Coccolithus pelagicus in light microscope studies are structurally different; some belonging to Ericsonia muiri (see Roth, 1970). Detailed studies of this group in the Neogene have not yet been undertaken. It is possible that Miocene and Pliocene forms also differ from Recent Coccolithus pelagicus in their ultrastructure and temperature tolerance.

The genus Scyphosphaera is considered a warm water genus although its distribution is often sporadic. It is fairly common in some samples from Site 142 but sparse in sediments from the Eastern Atlantic.

The absence of the genus Helicopontosphaera, Scyphosphaera and Pontosphaera from the Pliocene at Site 136 is not clearly understood. Pontosphaera and Scyphosphaera are not resistant to solution and could have been dissolved. The lack of Helicopontosphaera can not be explained by solution because Helicopontosphaera kamptneri and $H$. selli are fairly resistant to solution. Ecological factors could have been responsible for the exclusion of the above three genera from the area.

A comparison of the calcareous nannoplankton from nearshore areas and land sections with assemblages from the open ocean shows that the nearshore assemblages contain more diversified assemblages. Many species and genera are missing from open-ocean sediments (see Bukry et al. 1971). Some groups like the holococcoliths are easily destroyed by solution and might have lived in the open-ocean environment, but are not preserved in open-marine sediments.
Others like Braarudosphaera prefer a nearshore environment. Braarudosphaera is missing from all the samples studied here, except for the Lower Cretaceous from Sites 136 and 144. Rhabdosphaera tenuis, Blackites spinulus, Lanternithus minutus, Isthmolithus recurvus, Pedinocyclus larvalis, Transversopontis obliquipons and Pontosphaera multipora occur in small numbers in the Lower Oligocene from Site 144. These species which are indicative of nearshore conditions with moderate water depth are also present in the Oligocene of the Blake Plateau JOIDES Cores (see Roth, 1970 and Bukry, 1970), but are absent from open-ocean deposits of the same age: for example, at Site 10 of Leg 2.

The relative abundance of nannofossils is variable. Unusually high percentages of nannoplankton ( 80 to 90 per cent of the sediment) were observed in the Pleistocene to Miocene chalk oozes from Site 135 which consist almost exclusively of nannofossils. A high production rate for nannoplankton in that area is indicated for the Late Cenozoic.

\section{PRESERVATION OF NANNOFOSSILS AT EACH SITE}

\section{Site 135}

Nannoplankton recovered from Pleistocene to Upper Miocene chalk oozes of the first three cores is well preserved and shows only slight etching and some overgrowths mainly on ortholiths. Pontosphaera, Syracosphaera and in the upper part also Rhabdosphaera are present. In Core 4 more overgrowths on discoasters were observed. The Lower Miocene assemblages from the two sidewall cores are strongly etched and therefore the diversity is reduced. The clays of Eocene age recovered in Core 5 contain a solution residue consisting entirely of resistant ortholiths. The clays and muds from Cores 6 and 7 yield poorly-preserved etched Campanian assemblages. The black muds and limestones from Core 8 lack calcareous nannoplankton. The dark marl and limestones of Core 9 contain a well-preserved nannoflora. The presence of Braarudosphaera and Micrantholithus indicates nearshore conditions during the time of deposition.

\section{Site 136}

Nannoplankton from the chalk oozes in the upper part of the section show little etching and slight to moderate overgrowth in Core 1 (Pliocene), moderate etching and overgrowth in Core 2 (Middle Miocene), and strong etching of coccoliths and some overgrowths on the discoasters in Core 3. The silty clays of Core 4 (Lower Miocene) contain only very few and solution resistant species. The absence of delicate species like Pontosphaera, Scyphosphaera and Rhabdosphaera from the Tertiary at this site is due to solution. The clays of Core 5 are virtually barren of nannofossils and the clays from Core 6 contain a poor Campanian nannoflora which shows signs of etching. Core 7 lacks coccoliths. Core 8 and some chips found in the bumper sub yield very well-preserved rich Aptian assemblages. Nannoconus and Braarudosphaera occurring in some of the Aptian samples indicate near-shore conditions. 


\section{Site 137}

The brown clays in the first six cores are completely barren of fossils. Cores 9 through 16 recovered marl oozes with rich and well-preserved Cenomanian to Late Albian nannoplankton that show hardly any signs of etching or overgrowth.

\section{Site 138}

The muds and clays from this hole lack calcareous nannoplankton except for a few etched Cretaceous forms observed in Core 5.

\section{Site 139}

Cores 1 and 2 recovered Pliocene chalk ooze with well-preserved nannoplankton. Delicate species like Pontosphaera and Rhabdosphaera are preserved, and only slight etching and overgrowth was observed. The Middle Miocene nannoplankton from the marl oozes of Cores 3 and 4 is strongly etched. The diatom ooze of Core 5 contains a nannoflora which has been even more affected by solution. Core 6 lacks nannofossils, and Core 7 yields strongly etched Early Miocene assemblages.

\section{Site 140}

The Pliocene oozes from Core 1 contain well-preserved assemblages of calcareous nannoplankton. An increase in the degree of etching from top to bottom is observed. Core 2 recovered moderately to strongly etched assemblages of Early Miocene age which also show some overgrowths on the discoasters.

\section{Site 141}

The chalk oozes recovered in the first six cores contain well-preserved nannofossils. Etching increases in Core 6, and very strong dissolution effects are observed in Core 7 where practically only discoasters occur. The lower part of Core 7 and Cores 8 and 9 lack nannoplankton.

\section{Site 142}

The finer-grained layers of Cores 1 through 3 (Pleistocene) contain very well-preserved nannoplankton. Slight etching of the coccoliths and some overgrowths on discoasters were observed in the Pliocene assemblages of Core 4. Cores 5 and 6 (Pliocene) yield moderately to strongly etched coccoliths. The marl ooze recovered in Core 7 (Upper Miocene) show slightly etched nannofloras. Cores 8 and 9 (Upper and Middle Miocene) recovered marls with moderately to strongly etched coccoliths and discoasters with slight overgrowths.

\section{Site 143}

A very poor Aptian nannoflora with slightly etched coccoliths occurred in the samples recovered.

\section{Site 144}

Oligocene nannoplankton from the chalk oozes of Cores $1 \mathrm{~B}, 2 \mathrm{~B}, 1 \mathrm{~A}$, and $3 \mathrm{~B}$ is well preserved but with overgrowths on most discoasters. Coccoliths from Core $2 \mathrm{~A}$ are slightly etched. The Eocene nannoplankton in Cores 2 and 3A show slight etching and overgrowth. The Cretaceous part of Core $3 \mathrm{~A}$ contains slightly etched coccoliths which also show some overgrowths. Many of the delicate central structures are thicker than usual. Slight etching and moderate secondary calcification of the coccoliths are observed in Cores 3 and 4A. Only sparse nannoplankton which is affected by solution and overgrowth occurs in Cores 5A and 6A. The same state of preservation with slight etching and overgrowth characterizes the assemblages from the other Cretaceous cores at this site. Nannoplankton are very sparse in Cores 5, 6, 7 and 8, but somewhat richer in Core 4. The presence of Braarudosphaera in the Aptian at this site indicates nearshore conditions.

\section{CORRELATION OF ZONES BASED ON NANNOPLANKTON AND ON PLANKTONIC FORAMINIFERA}

Mostly spot cores were taken during this leg. Therefore accurate correlation of the zones based on the two calcareous plankton groups is only possible for the Pliocene (based mainly on Site 141), the Lower Oligocene (Site 144), and for the Cenomanian (Site 137). For the other intervals the relative position of the zones is known, but there is considerable uncertainty about the relation of the boundaries. Therefore, they are indicated with dashed lines on Table 16.

The planktonic foraminiferal zonation used is the one proposed by Bolli (1957), Bolli (1966) and Bolli (1970). Most of the Ceratolithus tricorniculatus Zone can be correlated with the lower part of the Globorotalia margaritae Zone which is considered Pliocene by most micropaleontologists working in the type area of the Pliocene stages, (see Cati et al., 1968). The lowermost part of the Ceratolithus tricorniculatus Zone is probably still Late Miocene in age. This is also indicated by the presence of the marker species in uppermost Tortonian deposits from the type area (Bukry and Bramlette, 1968). The MiocenePliocene boundary seems to lie in the lower part of the Ceratolithus tricorniculatus Zone and not below or within the Ceratolithus rugosus Zone where it was drawn by Bukry (1971) and Martini and Worsley (1971). The AlbianCenomanian boundary is well defined in terms of planktonic foraminiferal zones but is difficult to determine by nannoplankton. Lithraphidites alatus $n$. sp. and Chiastozygus cuneatus first appear just above the AlbianCenomanian boundary.

\section{SYSTEMATICS}

\section{Cenozoic}

Most species of Cenozoic nannofossils used in this report are well described and illustrated in the literature. Reference to original descriptions can be found in the Annotated Index and Bibliography of Calcareous Nannoplankton Parts I to $\mathrm{V}$ by Loeblich and Tappan $\left(1966,1968,1969,1970_{a}\right.$, $1970 \mathrm{~b}$ ). Species which are transferred to another genus or which are used in a slightly different sense compared to other authors are discussed below.

\section{Pseudoemiliana lacunosa (Kamptner) Gartner}

1963 Ellipsoplacolithus lacunosus Kamptner, p. 172, pl. 9, fig. 50 . 
1967 Coccolithus doronicoides Black of McIntyre, Be' and Preikstas (pro parte) p. 8, pl. 3, fig. A.

1968 Umbilicosphaera cricota (Gartner) of Gohen and Reinhardt, p. 296, pl. 19, figs. 1, 2; pl. 21, fig. 3.

1969 Pseudoemiliania lacunosa (Kamptner) Gartner, p. 598 , pl. 2, figs. 9-10.

Although this species is invalid (Loeblich \& Tappan, $1970_{\mathrm{a}}$ ) it is used in this report. It is a highly variable species including elliptical and circular forms. Detailed electron and light microscope studies should precede taxonomic revision of this species. It is most abundant in the Lower Pleistocene but it is also present in the Pliocene.

\section{Reticulofenestra abisecta (Müller) n. comb.}

1970 Coccolithus aff. C. bisectus (Hay, Mohler and Wade). Bramlette and Wilcoxon, p. 102, pl. 4, figs. 9-10.

1970 Coccolithus? abisectus Muller, p. 92, pl. 9, figs. 9-10; pl. 12 , fig. 1.

1971 Dictyococcites abisectus (Muller) Bukry and Percival, p. 127 , pl. 2, figs. 9-11.

Reticulofenestra reticulata (Gartner and Smith) $\mathrm{n}$. comb.

1967 Cyclococcolithus reticulatus Gartner and Smith, p. 4, pl. 5, fig. 1-4.

1970 Cyclococcolithina reticulata (Gartner and Smith) Wilcoxon, p. 83.

This circular placolith exhibits structures which are characteristic of the genus Reticulofenestra. The central depression is spanned by a grille and is surrounded by a cycle of strongly imbricate elements as seen in distal view (see Gartner and Smith, pl. 5, fig. 1). The extinction pattern is also typical of the genus Reticulofenestra. The shields are bright to the periphery and the extinction figure consists of four wide dots close to the margin. The distinct cross in the center is a unique feature of this species. Reticulofenestra reticulata (Gartner and Smith) n. comb. occurs fairly commonly in the Upper Middle and Upper Eocene.

\section{Cyclococcolithina floridana (Roth and Hay)}

n. comb.

1967 Coccolithus floridanus Roth and Hay in Hay et al., 1967 1967, p. 445, pl. 6, figs. 1-4.

1967 Cyclococcolithus neogammation Bramlette and Wilcoxon, p. 104, pl. 1, figs. 1-3, pl. 4, figs. 3-5.

1970 Cyclococcolithus floridanus (Roth and Hay) Roth, $\mathrm{p}$. 854 , pl. 5 , fig. 6 .

\section{Helicopontosphaera obliqua (Bramlette and Wilcoxon)} n. comb.

1967 Helicosphaera obliqua Bramlette and Wilcoxon, p. 106, pl. 5, figs. 13-14.

\section{Pontosphaera distincta (Bramlette and Sullivan)}

$$
\text { n. comb. }
$$

1961 Discolithus distinctus Bramlette and Sullivan 1961, p. 141 , pl. 2 , figs. 8 a-b, 9 a-c.

\section{Pontosphaera rimosa (Bramlette and Sullivan) n. comb.}

1961 Discolithus rimosus Bramlette and Sullivan, p. 143, pl. 3 , figs. 12 a-c, 13 .

\section{Discoaster divaricatus Hay}

1967 Discoaster divaricatus Hay in Hay et. al., p. 451, pl. 3 , figs. 7-9.

1967 Discoaster aulakos Gartner, p. 2, pl. 4, figs. 4-5.

All discoasters with thick-ended rays, broad, bifurcating usually notched but sometimes flat ray tips, and angular interray spaces are included in this species. Discoaster deflandrei has rounded interray spaces. Discoaster divaricatus is fairly common in the Lower and Middle Miocene.

\section{Discoaster woodringi Bramlette and Riedel}

1954 Discoaster woodringi Bramlette and Riedel 1954, p. 400 , pl. 39 , figs. 8 a-b.

1961 Discoaster trinus Stradner, p. 85, text- fig. 85.

1967 Discoaster cubensis Furrazola - Bermudez and Ituralde - Vinent, p. 10, pl. 2, figs. 6-7.

1967 Discoaster triguarensis Furrazola - Bermudez and Ituralde - Vinent, pp. 9-10, pl. 2, figs. 3-4.

Robust discoasters with thick rays joined throughout most of their length. Prominent sutures between rays extend almost to the center. Many specimens show signs of strong secondary calcite overgrowth, and it is possible that Discoaster woodringi is an artificial species caused by recrystallization of Discoaster deflandrei, D. tani, D. divaricatus, and others. Discoasters assigned to this species are most abundant in the Oligocene and Lower Miocene.

\section{Cretaceous}

Some new and stratigraphically useful species are described and others are transferred to a different genus. The scanning electron microscope photographic negatives of the holotypes, paratypes and hypotypes are deposited at the Naturhistorisches Museum Basel and identified by the author's negative numbers (listed in square brackets) and by the Basel Museum collection numbers.

\section{Family ARKHANGELSKIELLACEAE Bukry, 1969 Genus GARTNERAGO Bukry, 1969}

Gartnerago concavum (Gartner, 1968)

Bukry, 1969

Gartnerago diversum Thierstein n. sp. (Plate 15, Figures, 9-15)

Description: Four rim tiers are visible on the proximal side, each consisting of about 70 elements. The innermost proximal rim tier is built of counterclockwise inclined elongated elements. The central area is spanned by four protruding subaxial crossbars. Further perforations are arranged irregularly. The distal side shows a small outer cycle of clockwise inclined elements, and a second broad inner cycle with an irregular surface. On the distal side the four subaxial crossbars are protruding and the perforations lie in deep conical depression.

Remarks: Gartnerago diversum n. sp. is distinguished from all other species of the genus by the arrangement of its perforations and the presence of protruding crossbars. 
Maximum diameter: $10-24 \mu$.

Holotype: [4235] A928.

Paratypes: [4251] A929, [4258] A930.

Type locality: DSDP Leg 14-144A-5-1, $125 \mathrm{~cm}$.

Distribution: South Atlantic.

Known range: Cenomanian - Maestrichtian.

Family EIFFELLITHACEA Reinhardt, 1965, emend. Perch-Nielsen, 1968

Genus CRUCIELLIPSIS Thierstein, 1971

Type species: Cruciellipsis cuvillieri (Manivit, 1966) Thierstein, 1971

$$
\begin{gathered}
\text { Cruciellipsis chiasta (Worsley, 1971) Thierstein } \\
\text { n. comb. } \\
\text { (Plate 6, Figures 8-13) }
\end{gathered}
$$

Description: The two shields of this species consist of 27 to 29 slightly sinistrally imbricated elements. The elements of the smaller proximal shield are inclined clockwise, those of the wider distal shield are inclined counterclockwise when viewed from the proximal side. The small central opening is spanned by a heavy cross aligned along the axes of the ellipse. Distally the central cross carries four asymmetrically arranged short spurs.

Remarks: The species is easily identified by the asymmetric shape of the four processes on the central cross.

Hypotype: [4359] A931.

Distribution: Atlantic, Europe.

Known range: Berriasian-Cenomanian.

\section{Genus GLAUKOLITHUS Reinhardt, 1964}

Type species: Glaukolithus diplogrammus (Deflandre, 1954), Reinhardt, 1964

Glaukolithus elegans (Gartner, 1968 emend. Burky, 1969) Thierstein n. comb.

(Plate 10, Figures 16-20)

?1966 Zygolithus tractus Stover, p. 148. pl. 4: 10-12

1968 Zygodiscus elegans Gartner, p. 32, pl. 10: 3-6; pl. 12: 3,$4 ; \mathrm{pl} .27: 1$.

1969 Zygodiscus elegans Gartner, 1968 emend. Bukry, p. 59, pl. 34: 6-8.

Genus PARHABDOLITHUS Deflandre, 1952

Type species: Parhabdolithus liasicus Deflandre, 1952

Parhabdolithus infinitus (Worsley, 1971) Thierstein n. comb.

(Plate 9, Figure 6-16)

1971 Mitosia infinitae Worsley, p. 1311, pl. 1: 48-50.

Hypotypes: [4330] A934, [4364] A935.

Genus REINHARDTITES Perch-Nielsen, 1968

Type species: Reinhardtites anthophorus (Deflandre, 1959) Perch-Nielsen, 1968

Reinhardtites fenestratus (Worsley, 1971) Thierstein n. comb.

(Plate 8, Figures 1-12)

1971 Arkhangelskiella ? fenestrata Worsley, p. 1305, pl. 1: 33-35.

Description: The narrow outer wall is built of 40 to 50 dextrally imbricate elements which are inclined clockwise when viewed from the distal side. A second inner wall, which is not as high as the outer wall, consists of dextrally imbricate and clockwise inclined elements; it surrounds the central area. The central area is composed of irregular tabular crystals on the distal side, and of several concentric circles of small crystals on the proximal side. This species does not have a central opening nor a stem.

Hypotypes: [4379] A932, [4383] A933.

Distribution: Atlantic, Europe.

Known range: Late Hauterivian - Cenomanian.

$$
\text { Genus TEGUMENTUM Thierstein n. gen. }
$$

Type species: Tegumentum stradneri Thierstein n. sp.

Description: The species of the genus Tegumentum n. gen. have a wall of strongly imbricate elements, a proximal rim of small elements, X-shaped crossbars, and a band of nonimbricate tabular elements covering the outer margin of the wall. The genus Tegumentum $\mathrm{n}$. gen. is distinguished from other members of the family Eiffelitacea Reinhardt 1965, emend. Perch-Nielsen, 1968 by its cover of tabular, nonimbricate elements along the outside of the wall.

Tegumentum stradneri Thierstein n. sp. (Plate 1, Figure 7-15)

?1968 Zygolithus litterarius (Gorka, 1957) Stradner, Adamiker and Maresch, p. 39, Plate 34: 1, 5-7.

Description: The wall is composed of about 40 elements with a strong dextral imbrication which are separated by clockwise inclined sutures when viewed from the distal side. The wall is wider on the distal side than on the proximal side. The outer margin of the wall is covered by nonimbricate plates with only slightly clockwise-inclined sutures when viewed from the proximal side. These plates are connected by the small crystals which form the proximal rim. The central area is spanned by small diagonal crossbars which are composed of many small blocky crystals proximally and of elongated elements distally. The crossbars meet in the center and rise above the distal margin of the wall.

Remarks: This species is distinguished from Chiastozygus litterarius Gorka, 1957 by the presence of coverplates along the outer margin of the wall. Under crossed-nicols the rim appears wide and bright and each crossbar consists of two elongate parts of different crystallographic orientation.

Maximum diameter: $4.5-9.5 \mu$.

Holotype: [4028] A918.

Paratypes: [4226] A919, [3024] A920.

Type locality: DSDP Leg 14-137-14-2, $132 \mathrm{~cm}$.

Distribution: Atlantic, Europe.

Known range: Late Barremian - Maestrichtian.

Family PODORHABDACEAE Noel, 1965

Genus PODORHABDUS Noel, 1965

Type species: Podorhabdus grassei Noel, 1965

Podorhabdus decorus (Deflandre, 1954) Thierstein n. comb.

(Plate 4, Figure 7, 9, 10-13)

1954 Rhabdolithus decorus Deflandre, in: Deflandre and Fert, p. 159, pl. 13: 4-6; text-fig. 87. 
1964 Cretarhabdus decorus (Deflandre 1954) Bramlette and Martini, p. 300, pl. 3: 9-12.

1965 Ahmuellerella ? granulata Reinhardt, p. 39, pl. 1:4.

1969 Podorhabdus granulatus (Reinhardt 1965) Bukry, p. 37, pl. 16: 4-6.

Family STEPHANOLITHIONACEAE Bukry, 1969

Genus COROLLITHION STRADNER, 1961 emend. Reinhardt, 1970b.

Type species: Corollithion exiguum Stradner, 1961

Corollithion acutum Thierstein n. sp.

(Plate 2, Figure 1-9)

Description: The elliptical wall of 40 to 50 nonimbricate elements is surmounted by a narrow rim. The central area is spanned by a compressed $\mathrm{X}$-shaped cross with acute angles between the crossbars in the short axis of the ellipse.

Remarks: Corollithion acutum n. sp. differs from Corollithion achylosum (Stover 1966) by having diagonal crossbars, whereas Corollithion achylosum (Stover 1966) has its crossbars approximately in the axes of the ellipse.

Maximum diameter: $6-7 \mu$.

Holotype: [3609] A921.

Paratype: [3606] A922.

Type locality: DSDP Leg 14-136-8-2, $142 \mathrm{~cm}$.

Distribution: South Atlantic.

Known range: Aptian-Campanian.

Family BRAARUDOSPHAERACEAE Deflandre, 1947

Genus HA YESITES Manivit, 1971

Type species: Hayesites albiensis Manivit, 1971

Hayesites bulbus Thierstein n. sp.

(Plate 2, Figure 20-23)

Description: A species of Hayesites Manivit, 1971 with usually eight rays. The ray tips are asymmetrically thickened on the lefthand side when viewed from the distal side. On the distal side, the elevated center carries a knob consisting of eight counterclockwise inclined elements. The rays meet in the center on the concave proximal side.

Remarks: Hayesites bulbus n. sp. differs from Hayesites albiensis Manivit, 1971, from Rucinolithus ? biradiatus Worsley, 1971 and from Rucinolithus ? radiatus Worsley, 1971 by its asymmetrically enlarged ends of the rays.

Maximum diameter: $7-9 \mu$.

Holotype: [3611] A925.

Type locality: DSDP Leg 14-136-8-2, $142 \mathrm{~cm}$.

Distribution: Atlantic.

Known range: Barremian - Aptian.

Genus RUCINOLITHUS Stover, 1966

Type species: Rucinolithus hayi Stover, 1966

Rucinolithus irregularis Thierstein $\mathrm{n} . \mathrm{sp}$. (Plate 2, Figure 10-19)

?1966 Lithastrinus sp. in Stover, p. 150, pl. 7:23.
Description: A species of the genus Rucinolithus Stover with 9 to 11 dextrally imbricate elements of variable size, forming a low cone. A central perforation may be present or lacking.

Remarks: This species differs from Rucinolithus hayi Stover, 1966 and Rucinolithus wisei Thierstein, 1971 by the greater number of elements, and by their irregular size. Diameter: $5-7 \mu$.

Holotype: [3604] A923.

Paratype: [3826] A924.

Type locality: DSDP Leg 14-136-8-2, $142 \mathrm{~cm}$.

Distribution: Atlantic, Europe.

Known range: Aptian-Albian.

Incertae sedis

Genus LITHRAPHIDITES Deflandre, 1963

Type species: Lithraphidites carniolensis Deflandre, 1963

Lithraphidites alatus, Thierstein n. sp.

(Plate 3, Figure 1-8)

Description: This species of the genus Lithraphidites is characterized by four blades which are wider at one end than at the other.

The blades are narrow at one end and increase continuously in width in the upper four-fifths of the body reaching a maximum in a peak or notched crest. From there they are drawn out to a sharp point. The silhouette of the whole body looks very much like a closed umbrella without a handle or the feathers at the end of an arrow.

Remarks: This species differs from Lithraphidites carniolensis Deflandre, 1963 and from Lithraphidites quadratus Bramlette and Martini, 1964 by the asymmetry of its blades.

Length: $10-30 \mu$.

Holotype: [3326] A926.

Paratypes: [3035] A927.

Type locality: DSDP Leg 14-137-14-2, $132 \mathrm{~cm}$.

Distribution: South Atlantic.

Known range: Cenomanian.

\section{Explanation of Symbols on Tables 4 through 15}

The following symbols are used on the distribution charts (Tables 4 to 15):

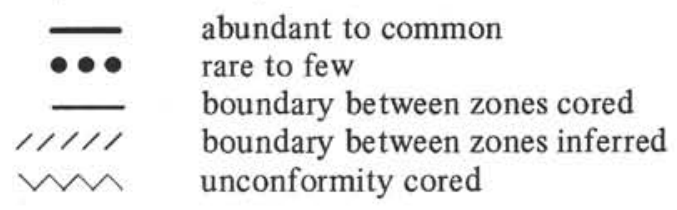

G, E-1, 0-1 preservation, see pp. 433 and 434 . 
TABLE 4

Roth \& Thierstein: Nannoplankton, Leg 14

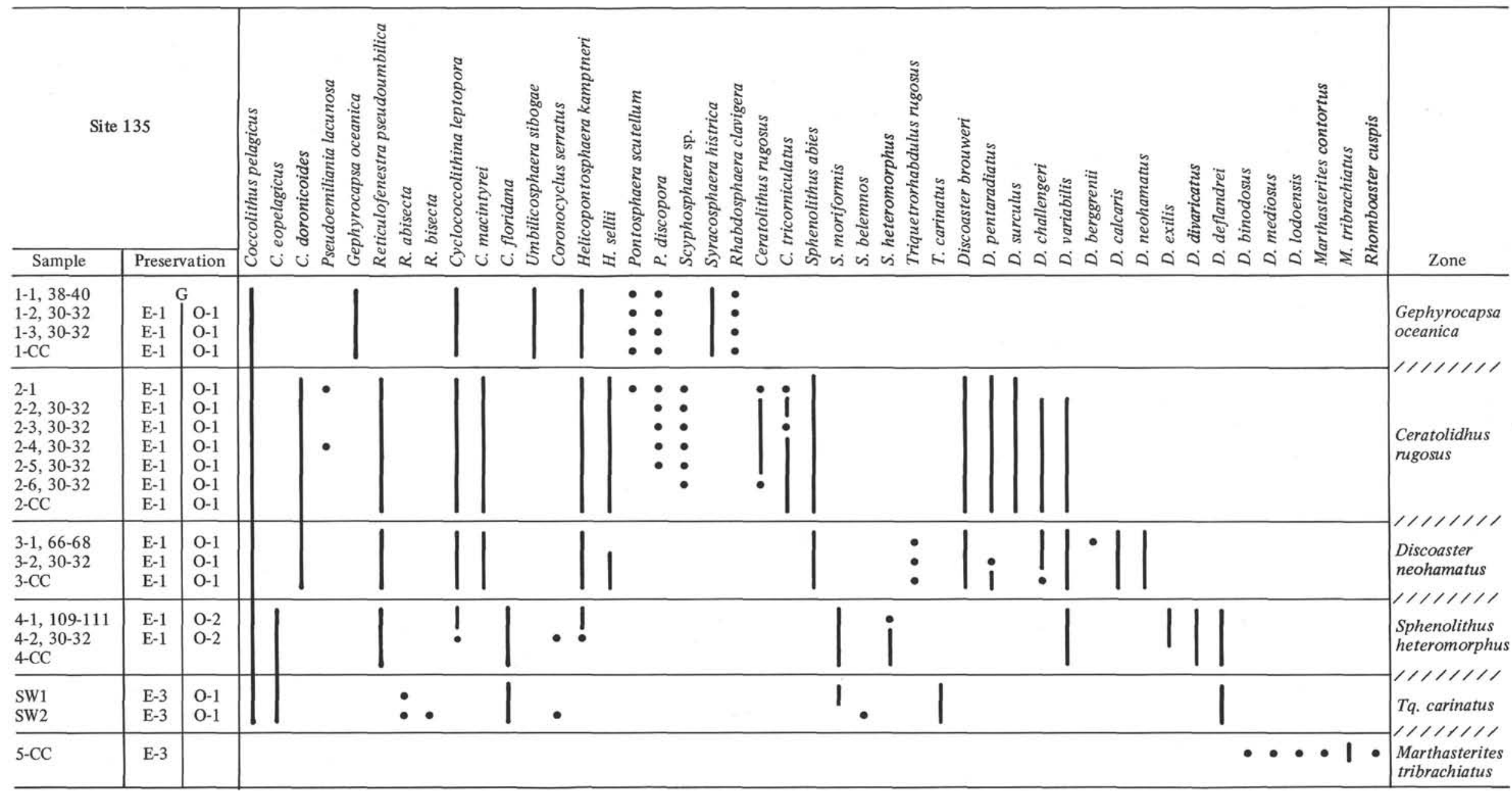


TABLE 5

Roth \& Thierstein: Nannoplankton, Leg 14

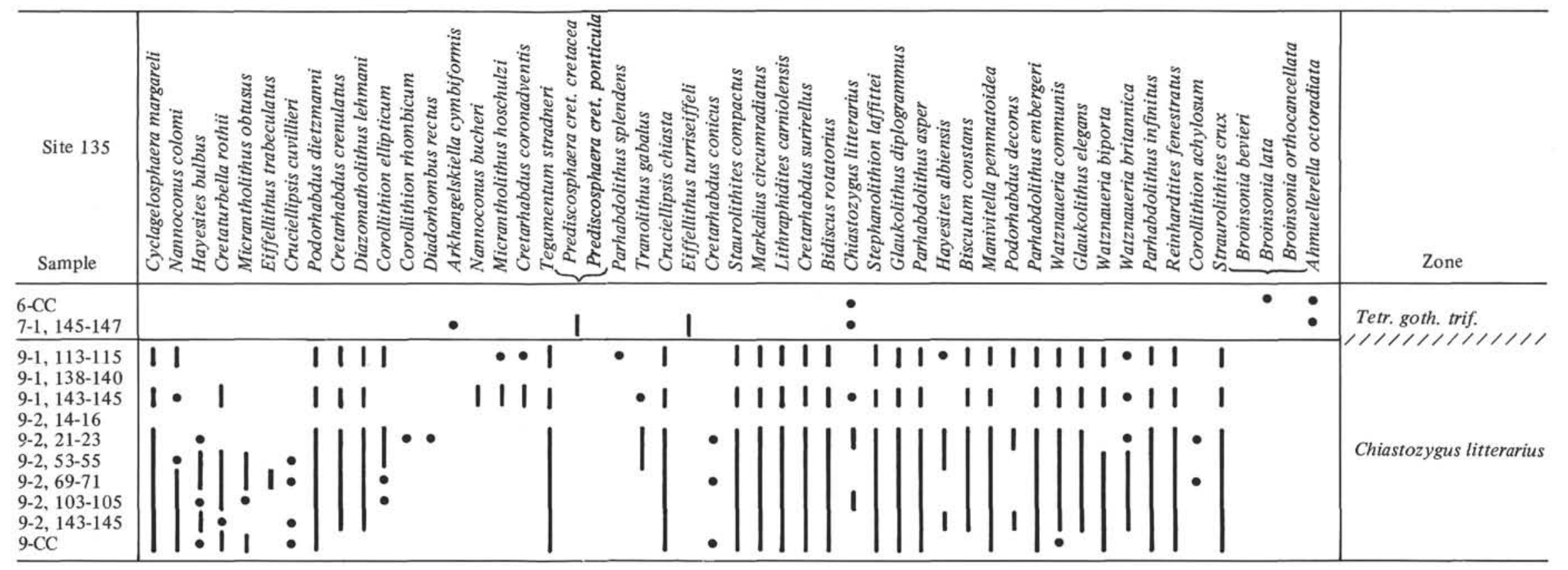


TABLE 6

Roth \& Thierstein: Nannoplankton, Leg 14

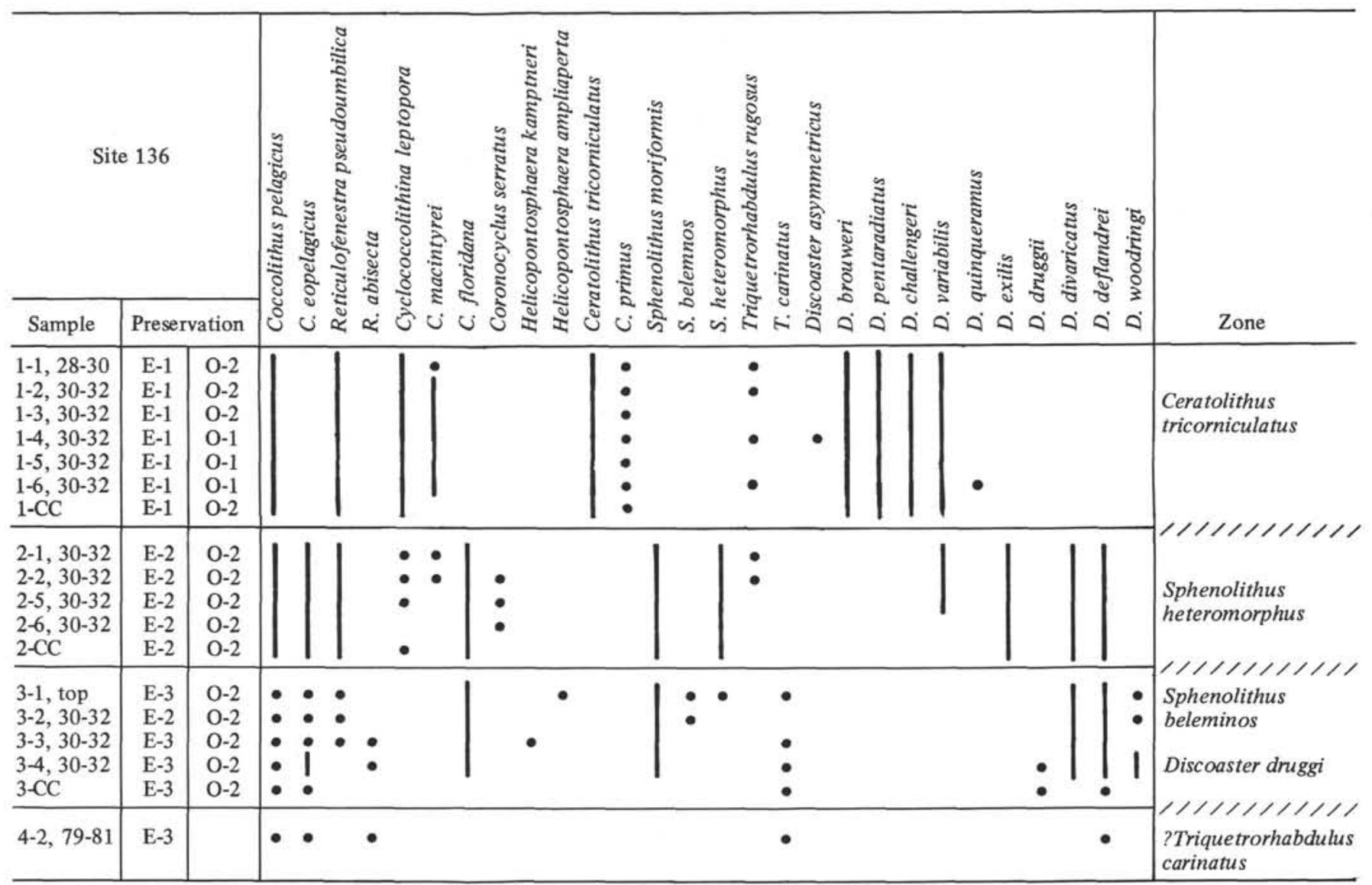


TABLE 7

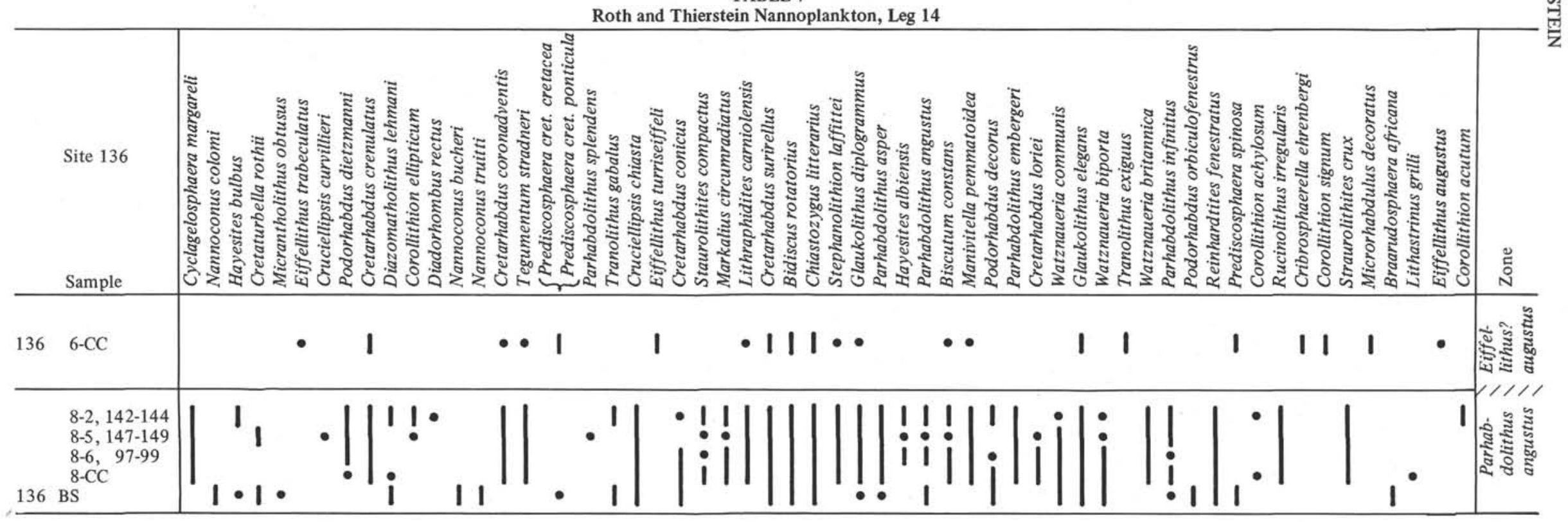




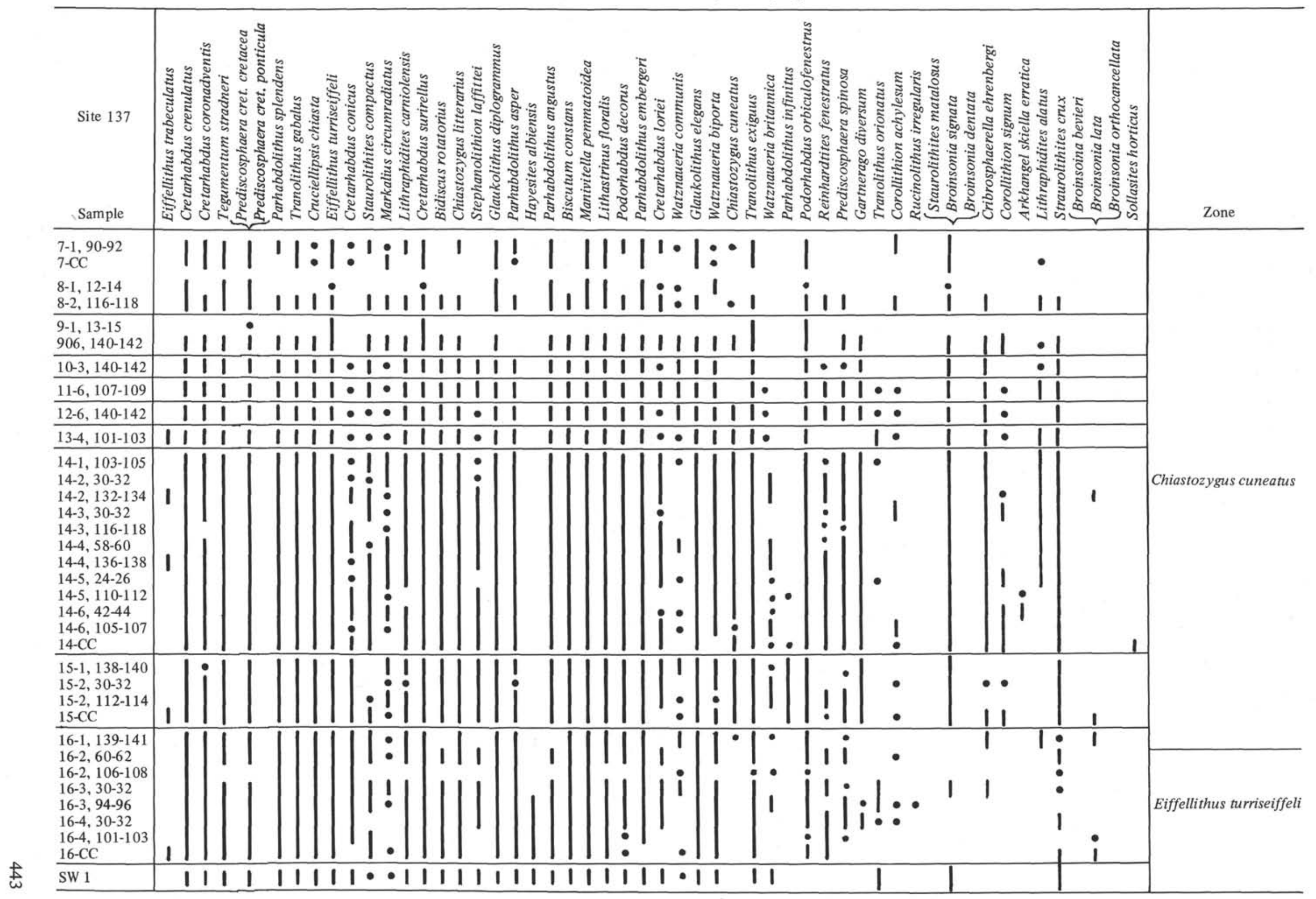




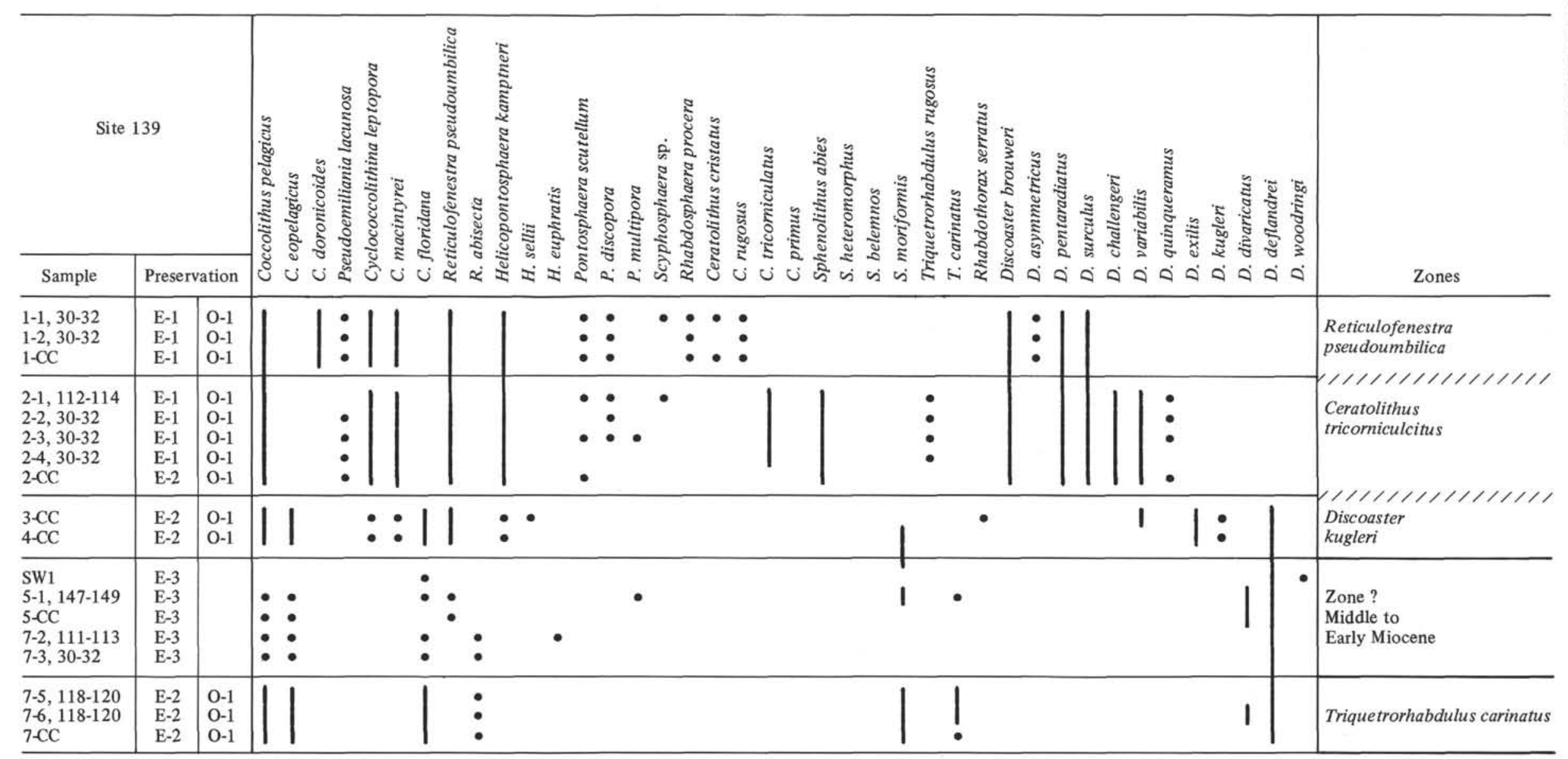


TABLE 10

Roth and Thierstein: Nannoplankton, Leg 14

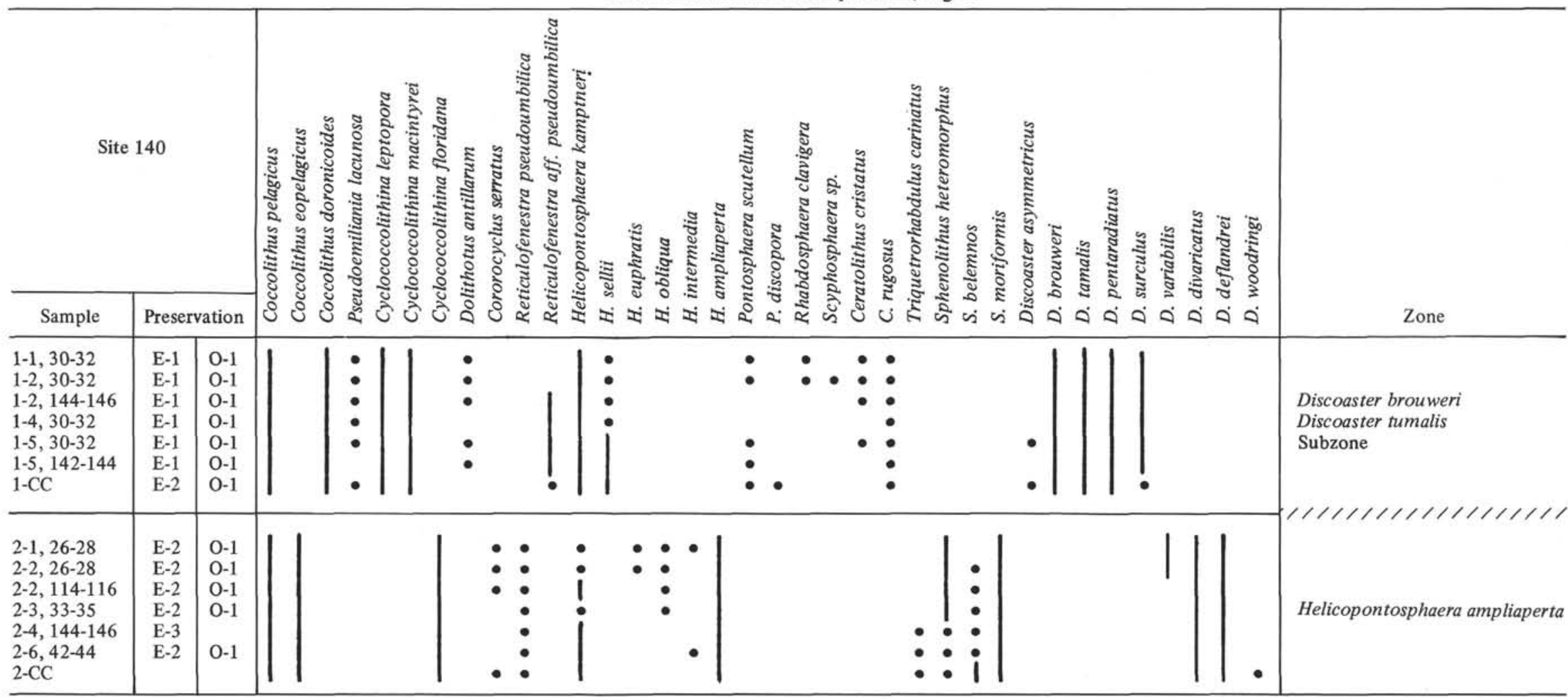


TABLE 11

Roth \& Thierstein: Nannoplankton, Leg 14

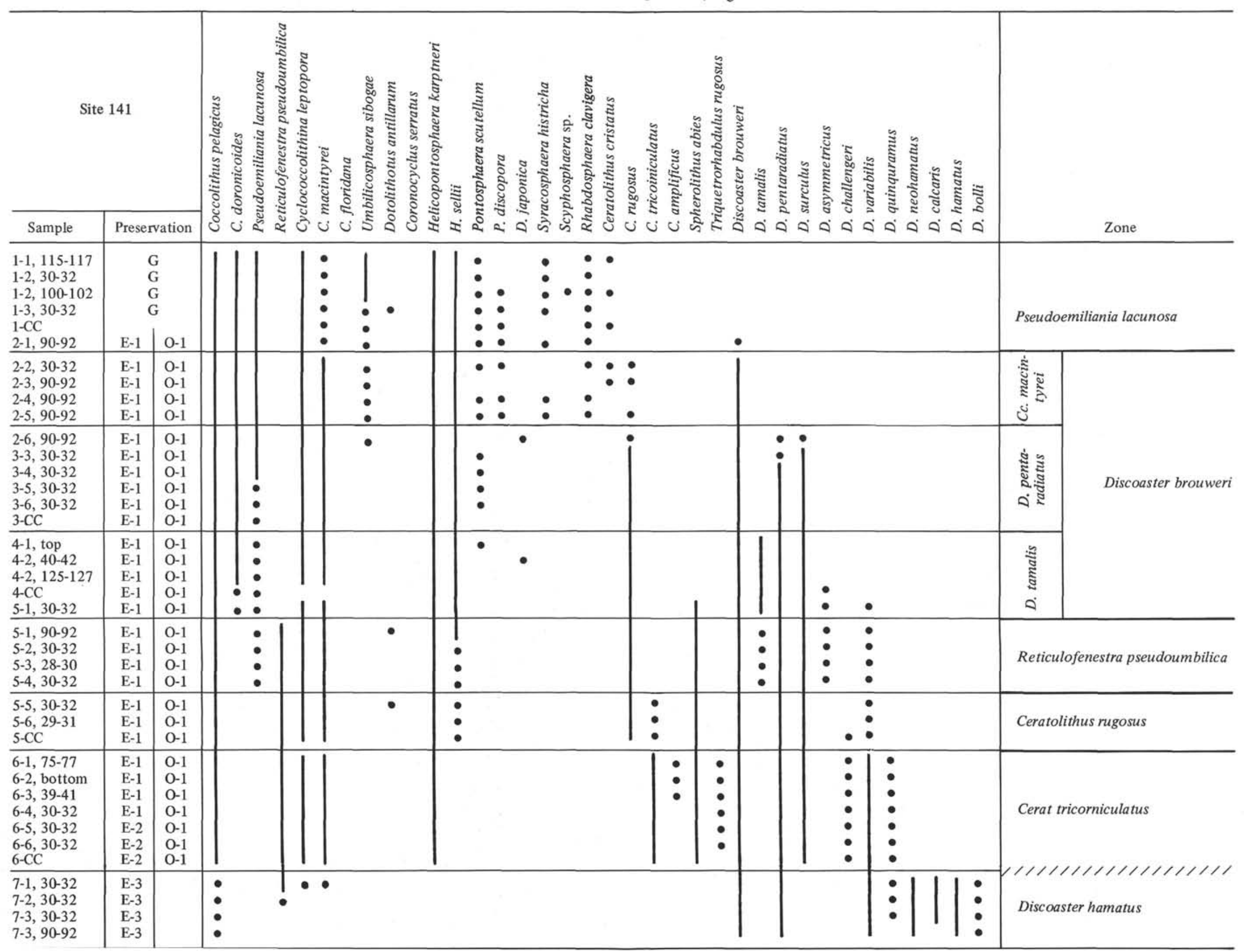


TABLE 12

Roth \& Thierstein: Nannoplankton, Leg 14

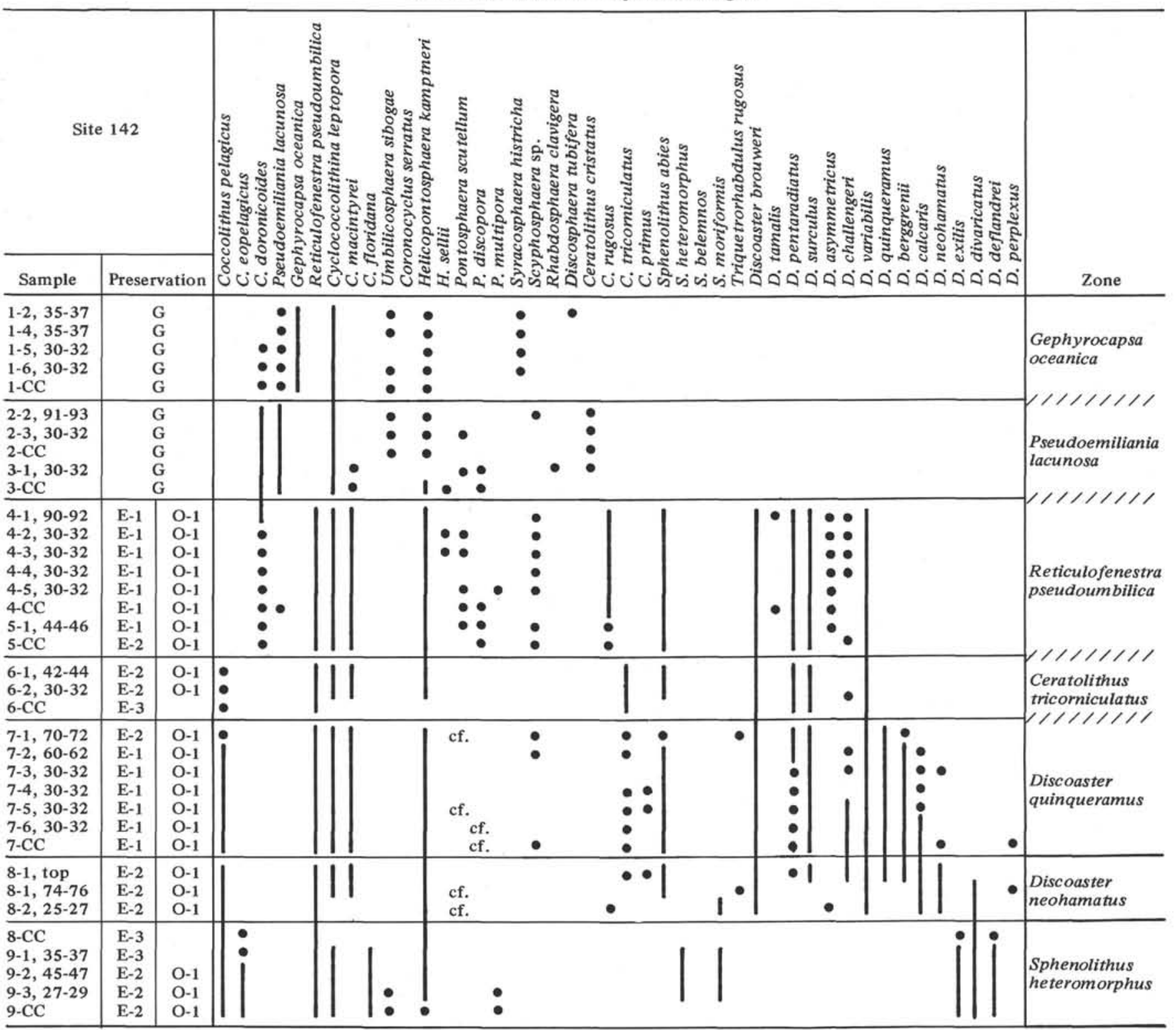

TABLE 13

Roth and Thierstein Nannoplankton, Leg 14

Site 143

Sample व

143 Bs | ・.... | | | | | | | | | | 
TABLE 14

Roth \& Thierstein: Nannoplankton, Leg 14

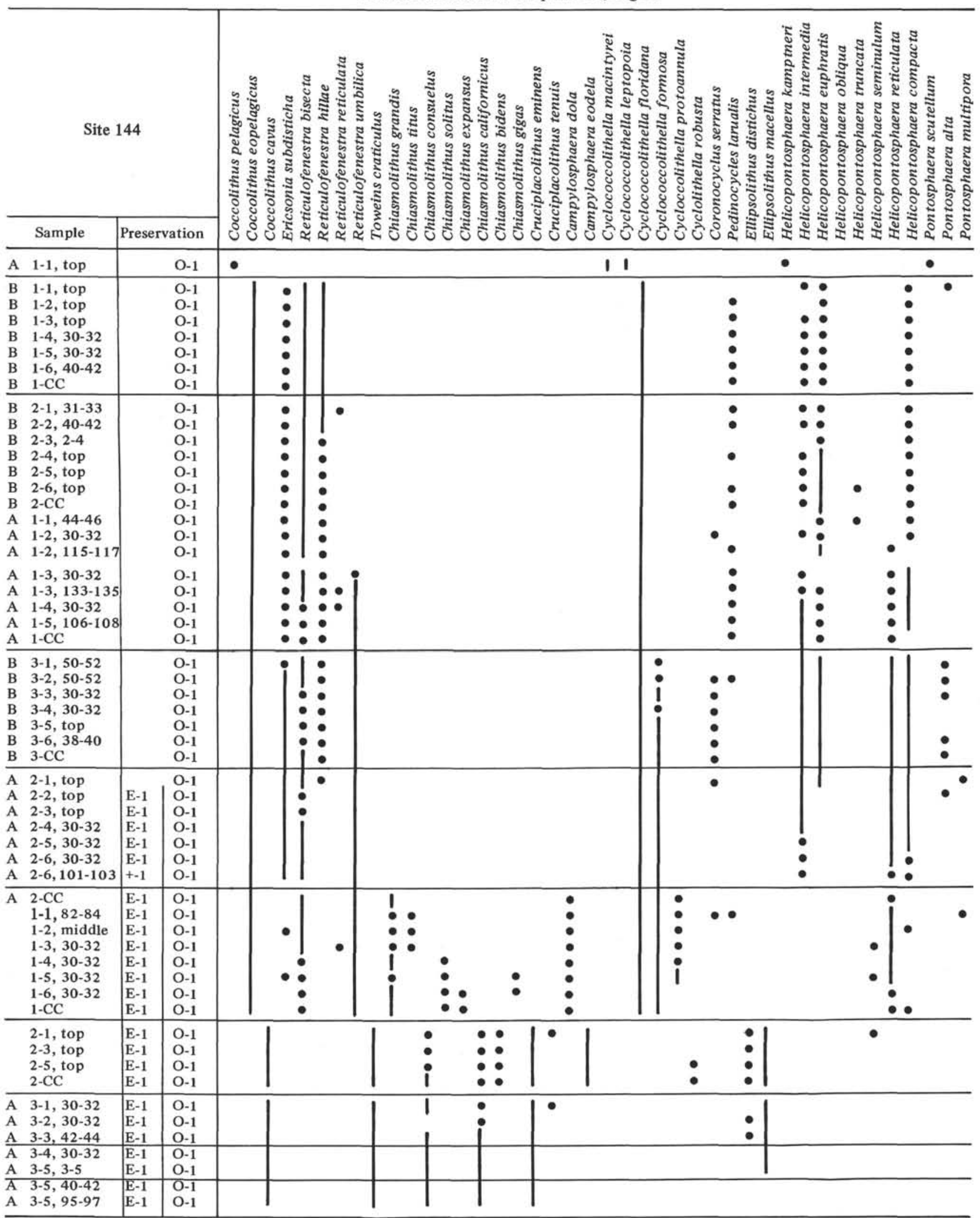




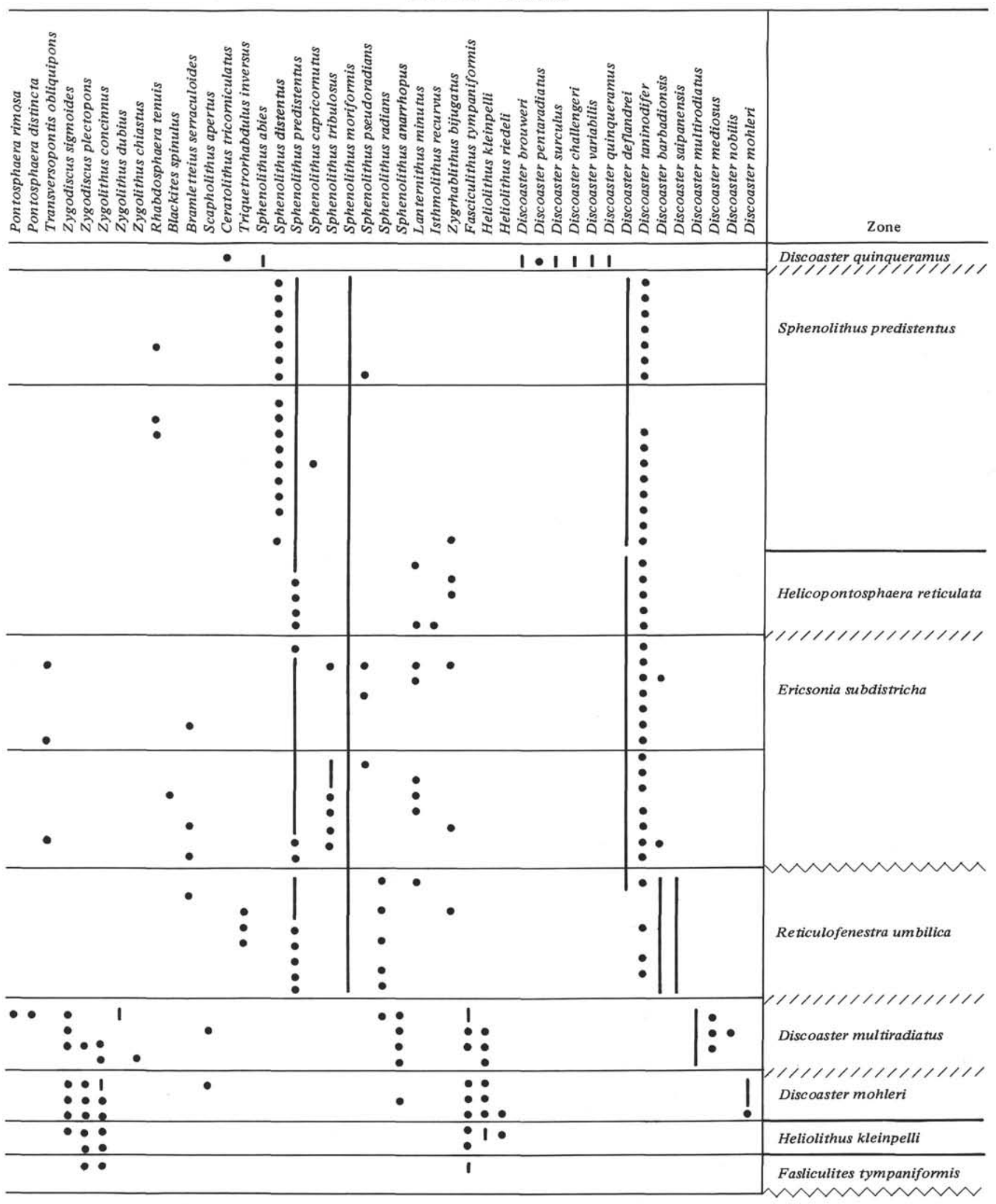


Roth \& Thierstein: Nannoplankton, Leg 14

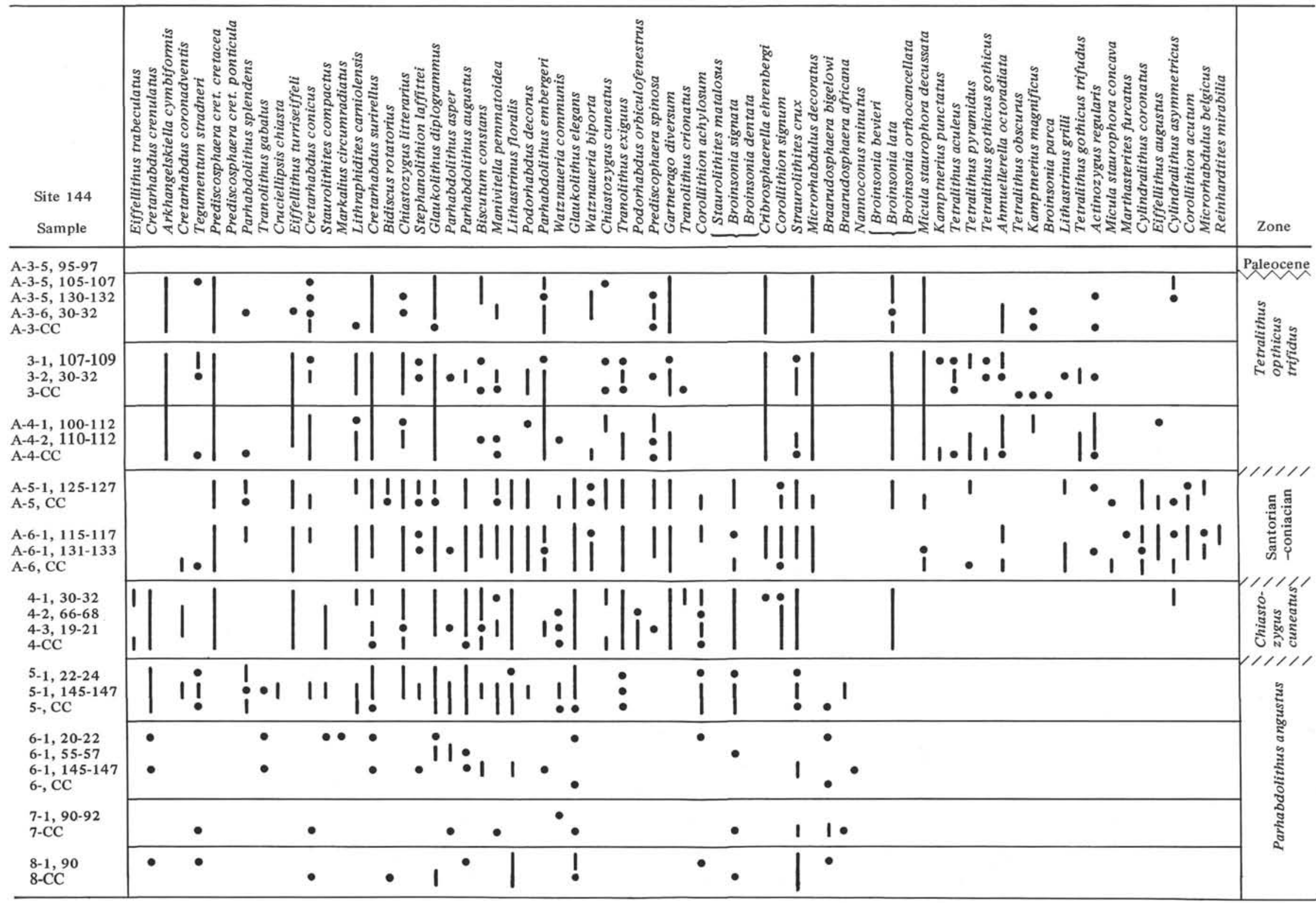


TABLE 16

Correlation of Zones Based on Planktonic Foraminifera and Nannoplankton

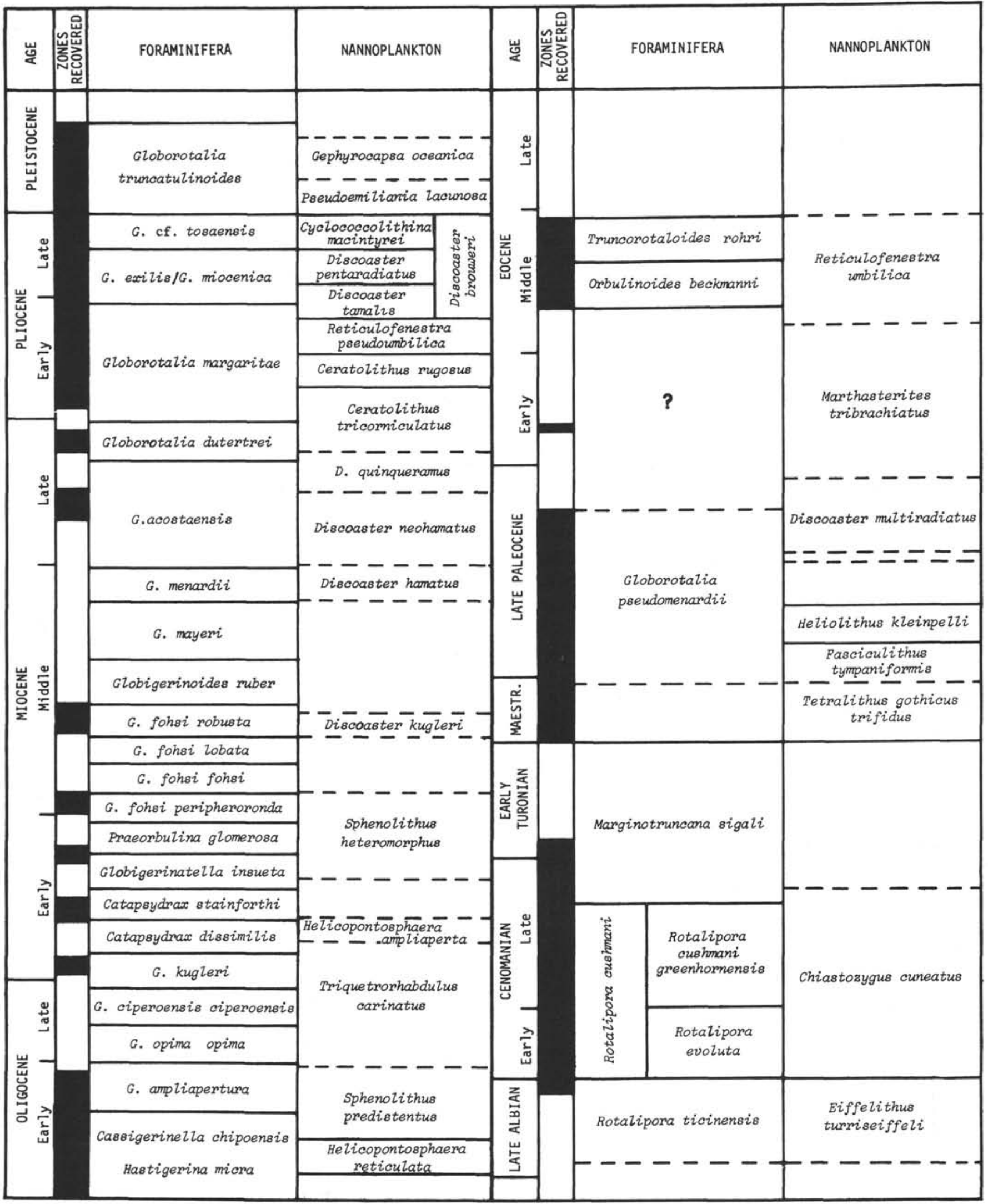




\section{REFERENCES}

Bramlette, M. N. and Martini, E., 1964. The great change in calcareous nannoplankton fossils between the Maestrichtian and Danian. Micropaleontology. 10 (3), 291.

Bramlette, M. N. and Riedel, W. R., 1954. Stratigraphic value of discoasters and some other microfossils related to recent coccolithorphores. J. Paleonthology. 28, 403.

Bramlette, M. N. and Sullivan, F. R., 1961. Coccolithophorids and related nannoplankton of the early Tertiary in California. Micropaleontology. 7 (4), 129.

Bramlette, M. N. and Wilcoxon, J. A., 1967. Middle Tertiary calcareous nannoplankton of the Cipero Section, Trinidad W. I. Tulane Studies Geology. 5, 93.

Bukry, D., 1969. Upper Cretaceous coccoliths from Texas and Europe. Kansas Univ. Paleont. Contr. Art. 51 (Protista 2).

, 1970. Coccolith age determinations Leg 2, Deep Sea Drilling Project. In Peterson, M. N. A. et al., 1970, Initial Reports of the Deep Sea Drilling Project, Volume II. Washington (U. S. Government Printing Office) 343. 1971. Coccolith stratigraphy Leg 7, Deep Sea Project. In Winterer, E. L. et al., 1971, Initial Reports of the Deep Sea Drilling Project, Volume VII. Washington (U. S. Government Printing Office) 1513.

Bukry, D. and Bramlette, M. N., 1970. Coccolith age determinations Leg 3, Deep Sea Drilling Project. In Maxwell, A. E. et al., 1970, Initial Reports of the Deep Sea Drilling Project Volume III. Washington (U. S. Government Printing Office) 589.

Bukry, D. and Percival, S. F., 1971. New Tertiary calcareous nannofossils. Tulane Studies Geology. 8, 123.

Cati, F., Colalonga, M. L., Crescenti, U., D'Onofrio, S., Follador, U., Pirini Radrizzani, C., Pomesano Cherchi, A., Salvatorini, G., Sartorini, S., Premoli Silva, I., Wezel, C. F., Bertolino, V., Bizon, G., Bolli, H. M., Borsetti Cati, A. M., Dondi, L., Feinberg, H., Jenkins, D. G., Perconing, E., Sampo, M. and Sprovieri, R., 1968. Biostratigraphia del Neogene mediterraneo basata sui foraminiferi planctonici. Boll. Soc. Geol. Ital. 87, 491.

Cepek, P. and Hay, W. W., 1969. Calcareous nannoplankton and Biostratigraphic subdivision of the Upper Cretaceous. Gulf Coast Assoc. Geol. Soc. Trans. 19, 323.

Cohen, C. L. D. and Reinhardt. P., 1968. Coccolithophorids from the Pleistocene Caribbean Deep-Sea Core CP-28. N. Jb. Geol. Palaontol. Abhande. 113 (3), 289.

Deflandre, G. and Fert, C., 1954. Observations sur les Coccolithophoridés actuels et fossiles en microscope ordinaire et electronique. Ann. Paleont. 40, 115.

Furrrazola-Bermudez, G. and Iturralde-Vinent, M., 1967. Estudio micropaleontologico del Oligoceno superior de Cuba, en el Pozo Pijuan No. 47. Rev. Technologica ( $L a$ Habana, Cuba). 5, 3.

Gartner, S., Jr., 1967. Calcareous nannofossils from Neogene of Trinidad, Jamaica, and Gulf of Mexico. Univ. Kansas Publ. State Geol. Surv. Paleontol. Contr. $29,1$.

1968. Coccoliths and related calcareous nannofossils from Upper Cretaceous deposits of Texas and Arkansas, Univ. Kansas Publ. State Geol. Surv. Paleontol. Contr. Protista Art. 1, 1.

1969. Correlation of Neogene planktonic foraminifer and calcareous nannofossil zones. Trans. Gulf Coast Assoc. Geol. Soc. 19, 585.

Gartner, S., Jr., and Smith, L. A., 1967. Coccoliths and related calcareous nannofossils from the Yazoo
Formation (Jackson, Late Eocene) of Louisiana. Univ. Kansas Paleontol. Contr. 20, 1.

Hay, W. W., Mohler, H., Roth, P. H., Schmidt, R. R. and Boudreaux, J. E., 1967. Calcareous nannoplankton zonation of the Cenozoic of the Gulf Coast and Caribbean-Antillean area, and transoceanic correlation. Gulf Coast Assoc. Geol. Soc. Trans. 17, 428.

Kamptner, E., 1963. Coccolithineen-Skelettreste aus Tiefsee ablagerungen des Pazifischen Ozeans. Ann. Naturh. Mus. Wien. 66, 139.

Loeblich, A. R., Jr. and Tappan, H., 1966. Annotated index and bibliography of the calcareous nannoplankton. Phycologia. 5, 81 . 1968. Annotated index and bibliography of the calcareous nannoplankton II. J. Paleontol. 42, 584. 1969. Annotated index and bibliography of the calcareous nannoplankton III. J. Paleontol. 43, 568. 1970a. Annotated Index and bibliography of the calcareous nannoplankton IV. J. Paleontol. 44, 558. , 1970b. Annotated Index and bibliography of the calcareous nannoplankton V. Phy cologia. 9, 157.

McIntyre, A., 1967. Coccoliths as paleoclimatic indicators of Pleistocene glaciation. Science. 158, 1314.

McIntyre, A. and Be', A. W. H., 1967. Modern Coccolithophoridae of the Atlantic Ocean - I. Placoliths and crytoliths. Deep-Sea Res. 14, 561.

McIntyre, A., Be', A. W. H. and Preikstas, R., 1967. Coccoliths and the Pliocene-Pleistocene boundary. Progress in Oceanogr. 4, 3 .

Manivit, H., 1971. Les nannofossiles du Crétace francais de l'Aptien au Danien. Essai de biozonation appuyee sur les stratotypes. Thèse Fac. Science d'Orsay.

Martini, E., 1970. Standard Paleogene calcareous nannoplankton zonation. Nature. 226 (5245), 560. 1971. Standard Tertiary calcareous nannoplankton zonation. In Proceedings of the II Plankt. Conf., Roma. A. Farninacci (Ed), Rome (Tecnoscienza).

Martini, E. and Bramlette, M. N., 1963. Calcareous nannoplankton from the experimental Mohole drilling. J. Paleontol. 37, 845.

Martini, E. and Worsley, T., 1970. Standard Neogene calcareous nannoplankton zonation. Nature. 225, 289. , 1971. Tertiary calcareous nannoplankton from the western equatorial Pacific. In Winterer, E. L. et al., 1971, Initial Reports of the Deep Sea Drilling Project, Volume VII. Washington (U. S. Government Printing Office), 1471.

Müller, C. 1970. Nannoplankton aus dem Mittel-Oligozan von Norddeutschland und Belgien. N. Jb. Geol. Paleontol. Abhandl. 135, 82 .

Reinhardt, P., 1965. Neue Familien fur fossile kalkflagellaten (Coccolithophoriden, Coccolithine en). Monatsber. Dt. Akad. Wiss. Berlin. 7, 30.

Roth, P. H., 1970. Oligocene calcareous nannoplankton biostratigraphy. Eclog. Geol. Helv. 63, 799.

Stover, L. E., 1966. Cretaceous coccoliths and associated nannofossils from France and the Netherlands. Micropaleontology. 12, 133 .

Stradner, H., Adamiker, D. and Maresh, O., 1968. Electron microscope studies on Albian calcareous nannoplankton from Felft 2 and Leidscham 1 Deepwells, Holland. Verh. Nederl. Ak. Weetsch., Afd. Natuurk. Ereste Reeks. 24 (4), 1.

Thierstein, H. R., 1971. Tentative Lower Cretaceous calcareous nannoplankton zonation. Eclog. Geol. Helv. 64 , in press. 
Thierstein, H., Franz, H. E. and Roth, P. H., 1972. Scanning electron microscopy of identical small particles. Micropaleontology. 18 , in press.

Wilcoxon, J. A., 1971. Cyclococcolithina nom. nov. (nom. subst. pro Cyclococcolithus Kamptner, 1954). Tulane Studies Geology. 8, 82.
Worsley, T., 1971. Calcareous nannoplankton zonation of Upper Jurassic and Lower Cretaceous sediments from the western Atlantic. In Proceedings II Plank. Conf. Roma. A. Farinacci (Ed), Rome (Tecnoscienze) 1301. 


\section{PLATE 1}

Figures 1-6 Chiastozygus litterarius (Gorka, 1957) Manivit, 1971 Leg 14-137-14-2, 132-134 cm.

1: Phase contrast, $3200 \mathrm{X}$ same specimen as Figure 3.

2: Transmitted light, $3200 \times$, same specimen as Figure 3.

3: Scanning electron micrograph of the distal side, $8000 \times$

4: Scanning electron micrograph of the proximal side, $8000 \times$.

5: Cross-polarized light, $3200 \mathrm{X}$, same specimen as Figure 3.

6: Scanning electron micrograph of the distal side, $60^{\circ}$ inclined, $12,000 \mathrm{X}$, same specimen as Figure 3.

Figures 7-15 Tegumentum stradneri Thierstein n. sp. Leg $14-137-14-2,132-134 \mathrm{~cm}$.

7: Scanning electron micrograph of the proximal side, $6500 \times$, holotype [4028] A918.

8: Phase contrast, $3200 \times$, same specimen as Figure 11.

9: Transmitted light, $3200 \times$, same specimen as Figure 11.

10: Cross-polarized light, $3200 \mathrm{X}$, same specimen as Figure 11.

11: Scanning electron micrograph of the distal side, $7000 \times$, paratype [4226] A919.

12: Scanning electron micrograph of the proximal side, $7000 \times$ paratype [3024] A920.

13: Phase contrast, $3200 \times$, same specimen as Figure 12.

14: Transmitted light, $3200 \mathrm{X}$, same specimen as Figure 12.

15: Cross-polarized light, $3200 \mathrm{X}$, same specimen as Figure 12. 
PLATE 1
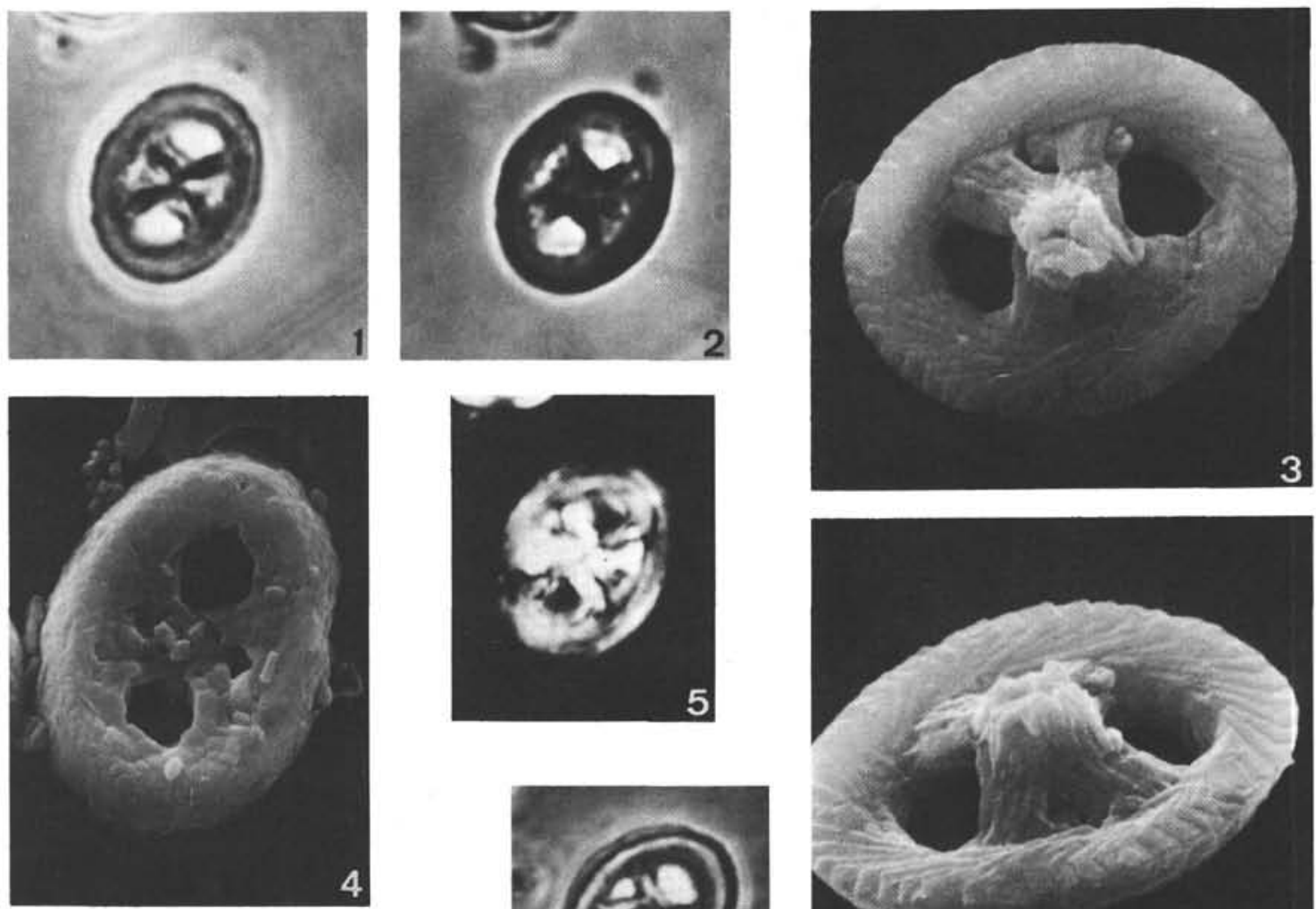

3
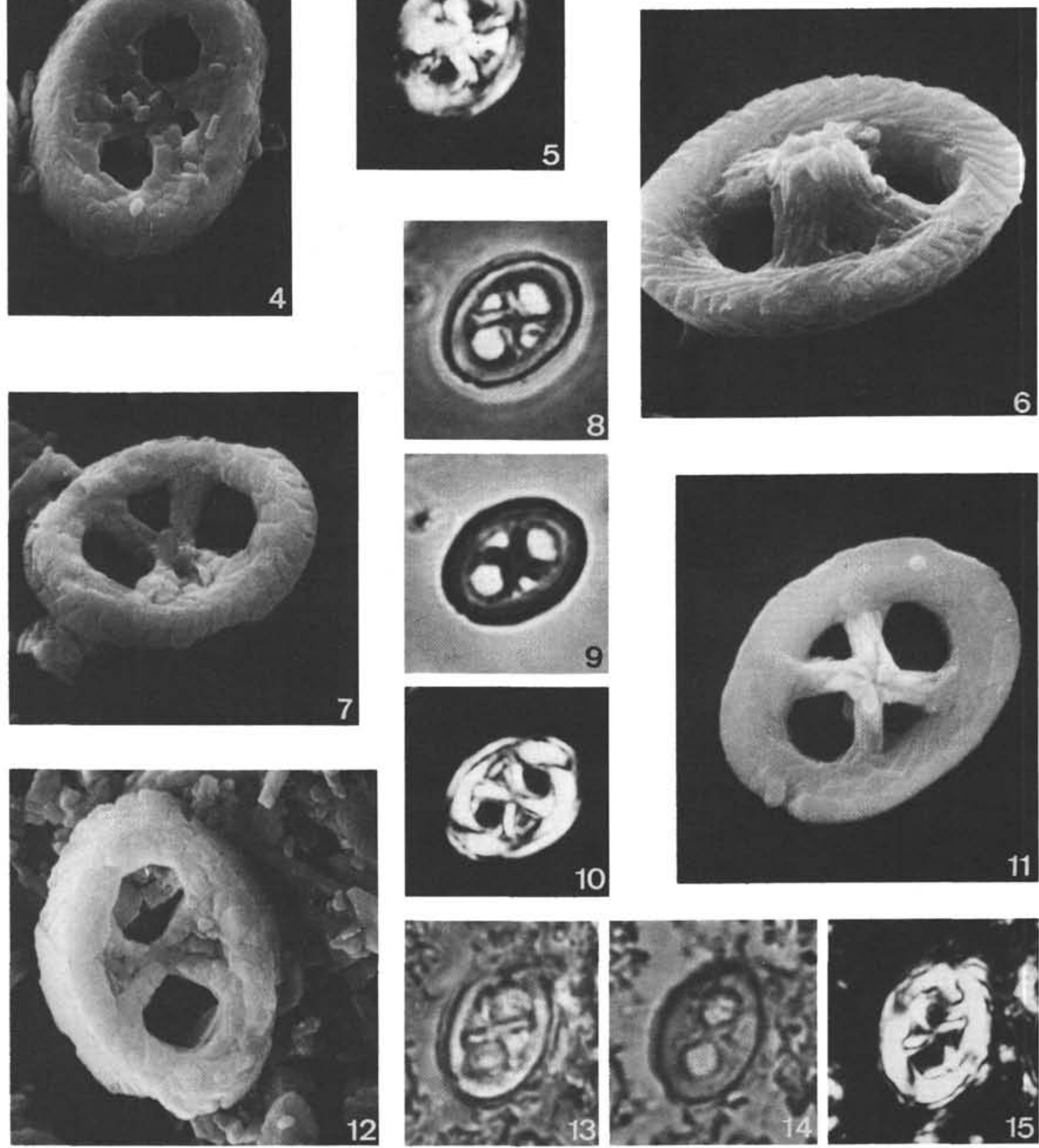


\section{PLATE 2}

Figures 1-9 Corollithion acutum Thierstein n. sp. Leg 14-136-8-2, $142-144 \mathrm{~cm}$.

1: Scanning electron micrograph of the proximal side, $6500 \times$, holotype [3609] A921.

2: Scanning electron micrograph of the proximal side, $60^{\circ}$ inclined, $7000 \mathrm{X}$, same specimen as Figure 1.

3: Scanning electron micrograph of the distal side, $6500 \times$, paratype [3606] A922.

4: Phase contrast, $3200 \times$, same specimen as Figure 1.

5: Transmitted light, $3200 \mathrm{X}$, same specimen as Figure 1.

6: Cross-polarized light, $3200 \mathrm{X}$, same speciman as Figure 1.

7: Phase contrast, $3200 \times$, same specimen as Figure 3.

8: Transmitted light, $3200 \mathrm{X}$, same specimen as Figure 3.

9: Cross-polarized light, $3200 \mathrm{X}$, same specimen as Figure 3.

Figures 10-19 Rucinolithus irregularis Thierstein n. sp. Leg $14-136-8-2,142-144 \mathrm{~cm}$.

10: Scanning electron micrograph of the proximal side, $6500 \times$, holotype [3604] A923.

11: Scanning electron micrograph of the proximal side, $45^{\circ}$ inclined, $7000 \mathrm{X}$, same specimen as Figure. 10.

12: Phase contrast, 3200 X, same specimen as Figure 10.

13: Transmitted light, $3200 \times$ same specimen as Figure 10.

14: Cross-polarized light, $3200 \mathrm{X}$, same specimen as Figure 10.

15: Scanning electron micrograph of the proximal side, $6500 \times$, paratype [3826] A924.

16: Transmitted light, $3200 \mathrm{X}$, same specimen as Figure 15.

17: Scanning electron micrograph of the proximal side, $60^{\circ}$ inclined, $6500 \mathrm{X}$, same specimen as Figure 15.

18: Phase contrast, 3200 X, same specimen as Figure 15.

19: Cross-polarized light, $3200 \mathrm{X}$, same specimen as Figure 15.

Figures 20-23 Hayesites bulbus Thierstein n. sp. Leg 14-136-8-2, $142 \mathrm{~cm}$.

20: Scanning electron micrograph of the distal side, $6500 \times$, holotype [3611] A925.

21: Phase contrast, $3200 \times$, same specimen as Figure 20.

22: Transmitted light, $3200 \mathrm{X}$, same specimen as Figure 20.

23: Cross-polarized light, $3200 \mathrm{X}$, same specimen as Figure 20. 


\section{PLATE 2}
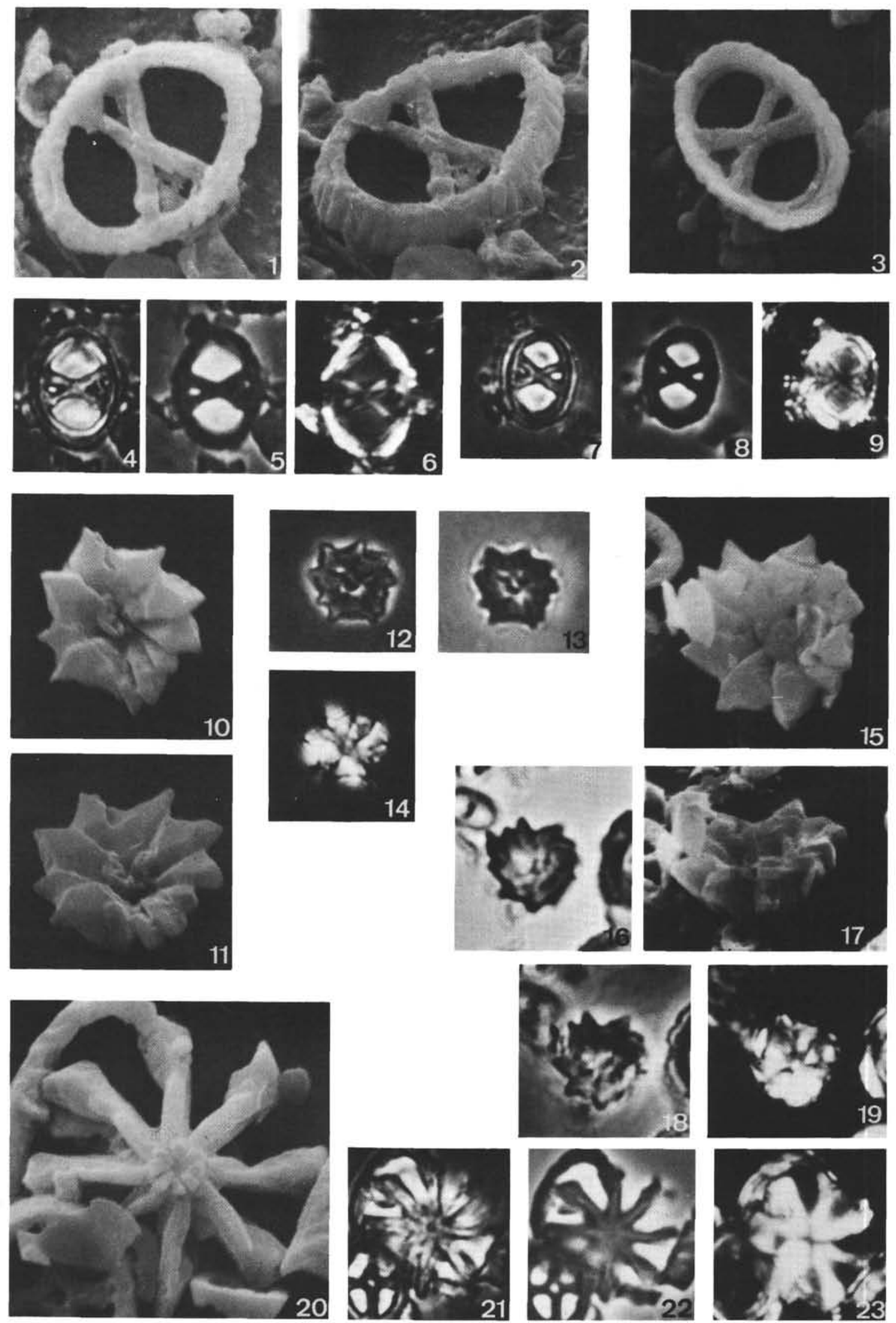


\section{PLATE 3}

Figures 1-8

Figures 9,12-14

Figures 10, 11, 15, 16
Lithraphidites alatus Thierstein n. $\mathrm{sp}$. Leg $14-137-14-2,132-134 \mathrm{~cm}$.

1: Scanning electron micrograph, $2800 \mathrm{X}$, holotype [3326] A926.

2: Phase contrast, $3200 \times$, same specimen as Figure 1.

3: Transmitted light, $3200 \mathrm{X}$, same specimen as Figure 1.

4: Cross polarized light, $3200 \mathrm{X}$, same specimen as Figure 1.

5: Scanning electron micrograph, $3500 \times$, paratype [3035] A927.

6: Phase contrast, $3200 \times$ same specimen as Figure 5.

7: Transmitted light, $3200 \times$, same specimen as Figure 5.

8: Cross-polarized light, $3200 \mathrm{X}$, same specimen as Figure 5.

Cretaturbella rothii Thierstein, 1971. Leg 14-135-9-2, $69-71 \mathrm{~cm}$.

9: Scanning electron micrograph, $6500 \mathrm{X}$.

12: Phase contrast, $3200 \times$, same specimen as Figure 9.

13: Transmitted light, $3200 \mathrm{X}$, same specimen as Figure 9.

14: Cross-polarized light, $3200 \times$, same specimen as Figure 9.

Microrhabdulus belgicus Hay and Towe, 1963 Leg 14-144A-5-1, 125-127 cm.

10: Phase contrast, $3200 \mathrm{X}$, same specimen as Figure 11.

11: Scanning electron micrograph, $6500 \mathrm{X}$.

15: Transmitted light, $3200 \mathrm{X}$, same specimen as Figure 11.

16: Cross-polarized light, $3200 \mathrm{X}$, same specimen as Figure 11. 
PLATE 3
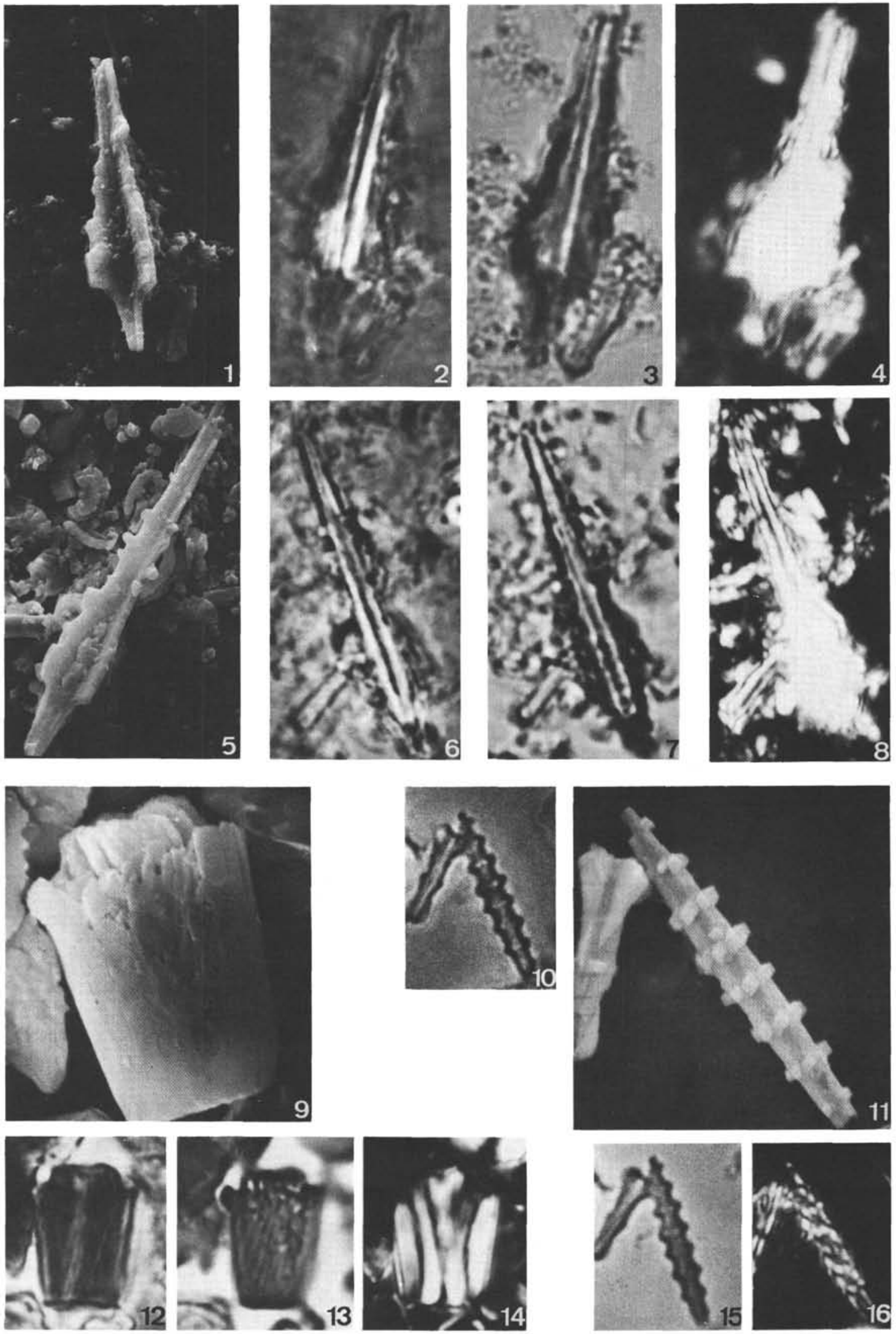


\section{PLATE 4}

Figures 1-6, 9

Figures 7, 8, 10-13
Eiffellithus turriseiffeli (Deflandre, 1954) Reinhardt, 1965

1: Scanning electron micrograph of the distal side, $6500 \times$, Leg 14-144A-5-1, top.

2: Phase contrast, $3200 X$, same specimen as Figure 1.

3: Transmitted light, $3200 \mathrm{X}$, same specimen as Figure 1.

4: Cross-polarized light, $3200 \mathrm{X}$, same specimen as Figure 1.

5: Scanning electron micrograph of the proximal side, $3200 \times$, Leg 14-137-14-2, 132-134 cm.

6: Scanning electron micrograph of the distal side, $6500 \times$, Leg 14-144-4-1, top.

9: Scanning electron micrograph of the proximal side, $6500 \times$, Leg 14-144-4-1, top.

Podorhabdus decorus (Deflandre, 1954) Thierstein n. comb.

7: Phase contrast, $3200 \times$, same specimen as Figure 13.

8: Transmitted light, $3200 \mathrm{X}$, same specimen as Figure 13.

10: Cross-polarized light, $3200 \mathrm{X}$, same specimen as Figure 13.

11: Cross-polarized light, $3200 \mathrm{X}$, same specimen as Figure 13.

12: Scanning electron micrograph of the proximal side, $5000 \times$, Leg 14-137-14-2, 132-134 cm.

13: Scanning electron micrograph of the distal side, $6500 \times$, Leg 14-144A-5-1, 125-127 cm. 


\section{PLATE 4}
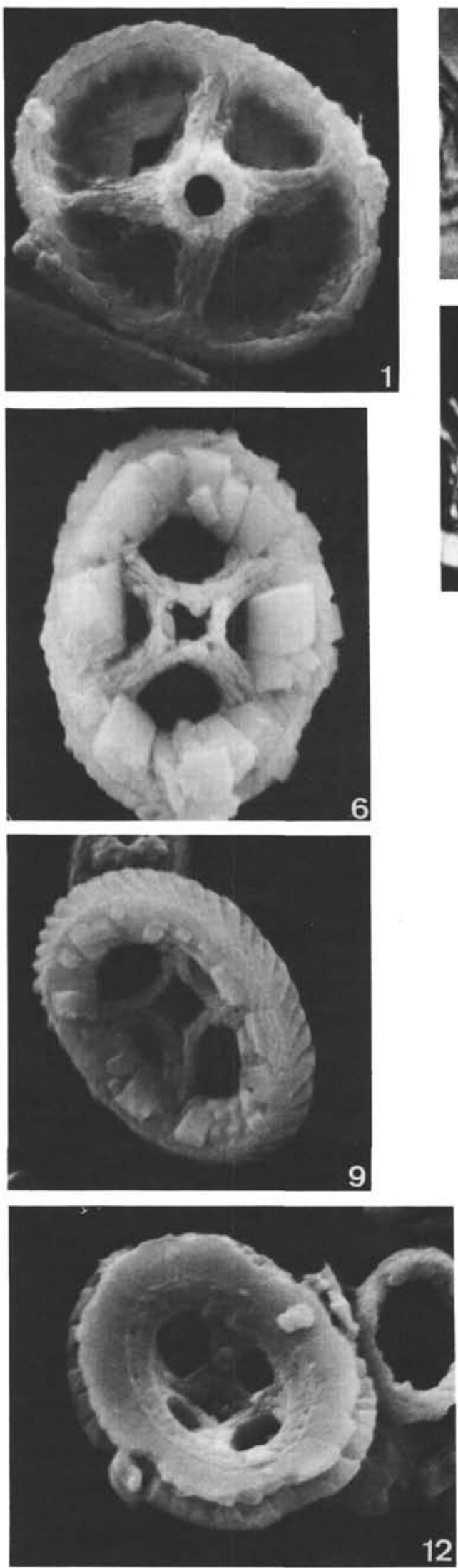
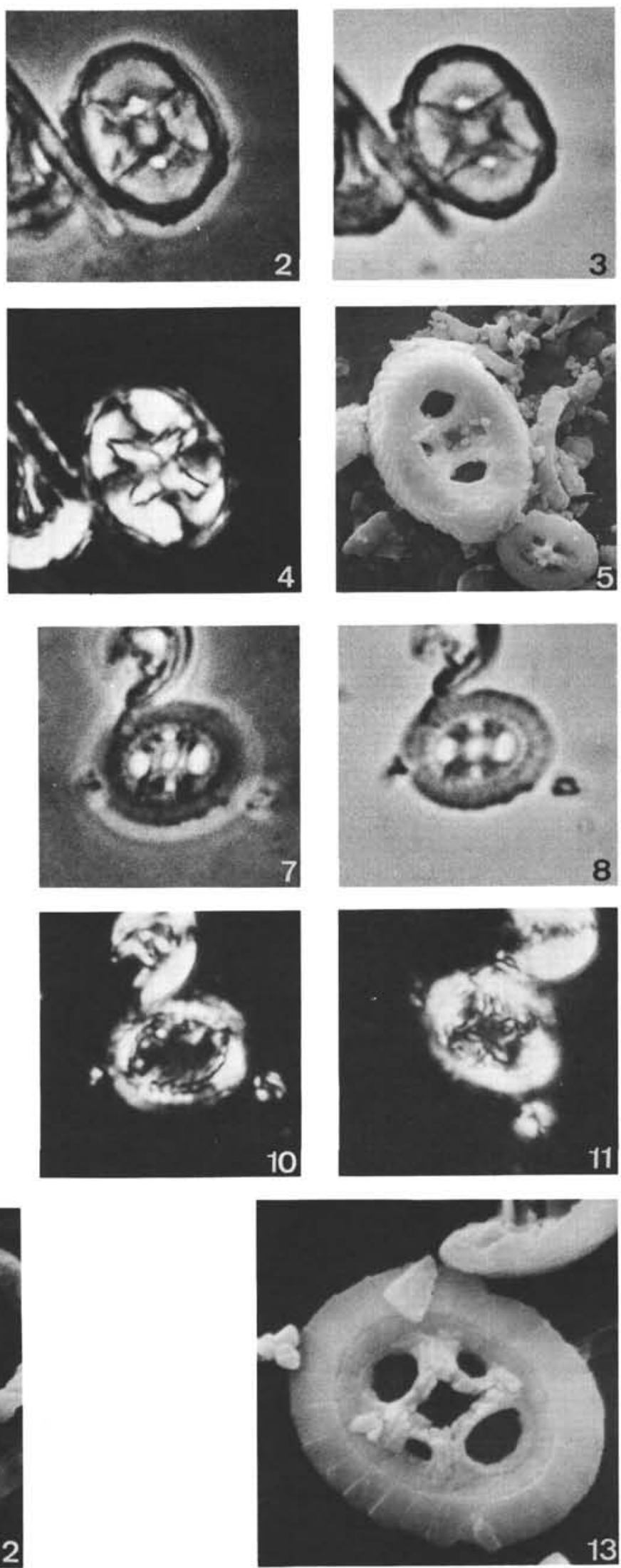


\section{PLATE 5}

Figures 1-9 Cretarhabdus coronadventis Reinhardt, 1966 Leg $14-137-14-2,132-134 \mathrm{~cm}$

1: Scanning electron micrograph of the distal side, $3200 \times$.

2: Phase contrast, $3200 \mathrm{X}$, same specimen as Figure 1.

3: Transmitted light, $3200 \times$, same specimen as Figure 1.

4: Scanning electron micrograph of the proximal side, $4500 \times .5$ :

5: Cross-polarized light, $3200 \mathrm{X}$, same specimen as Figure 1.

6: Phase contrast, $3200 \times$, same specimen as Figure 7.

7: Scanning electron micrograph of the distal side, $55^{\circ}$ inclined, $6500 \times$.

8: Transmitted light, $3200 \mathrm{X}$, same specimen as Figure 7.

9: Cross-polarized light, $3200 \times$, same specimen as Figure 7.

Figures 10-12 Cretarhabdus crenulatus Bramlette and Martini, 1964 emend. Thierstein, 1971

10: Scanning electron micrograph of the proximal side, $6500 \times$, Leg 14-135-9-2, $69-71 \mathrm{~cm}$.

11: Scanning electron micrograph of the proximal side, $6500 \times$, Leg 14-137-14-2, 132-134 cm.

12: Scanning electron micrograph of the distal side, $6500 \times$, Leg 14-144-4-1, top. 
Plate 5
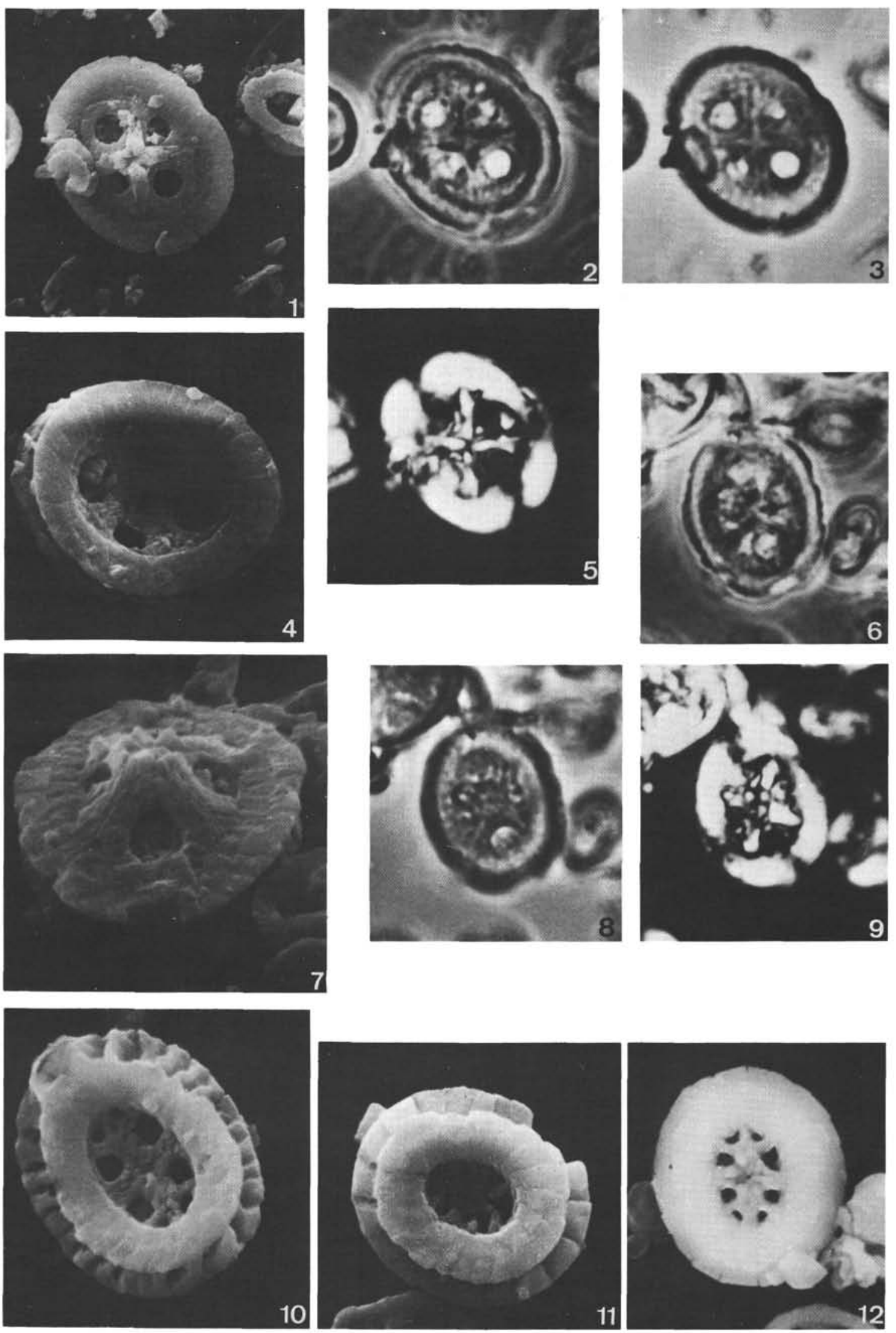


\section{PLATE 6}

Figures 1-7 Podorhabdus orbiculofenestrus (Gartner, 1968) Thierstein, 1971 Leg 14-137-14-2, 132-134 cm.

1: Scanning electron micrograph of the distal side, $7500 \times$.

2: Phase contrast, $3200 \mathrm{X}$, same specimen as Figure 1.

3: Transmitted light, $3200 \mathrm{X}$, same specimen as Figure 1.

4: Scanning electron micrograph of the distal side, $50^{\circ}$ inclined, $8500 \times$, same specimen as Figure 1 .

5: Cross-polarized light, $3200 \times$, same specimen as Figure 1 .

6: Cross-polarized light, $3200 \times$, same specimen as Figure 1.

7: Scanning electron micrograph of the proximal side, $6500 \times$.

Figures 8-13 Cruciellipsis chiasta (Worsley, 1971) Thierstein n. comb. Leg 14-137-14-2, 132-134 cm.

8: Scanning electron micrograph of the proximal side, $6500 \times$, hypotype [4359] A931.

9: Scanning electron micrograph of the distal side, $6500 \times$.

10: Phase contrast, $3200 \mathrm{X}$, same specimen as Figure 8.

11: Transmitted light, $3200 \mathrm{X}$, same specimen as Figure 8.

12: Cross-polarized light, $3200 \mathrm{X}$, same specimen as Figure 8.

13: Scanning electron micrograph of the distal side, $60^{\circ}$ inclined, $6500 \mathrm{X}$, same specimen as Figure 8 .

Figures 14-18 Parhabdolithus angustus (Stradner, 1963) Stradner, 1968 Leg 14-144A-5-1, 125-127 cm.

14: Phase contrast, $3200 \mathrm{X}$, same specimen as Figure 17.

15: Transmitted light, $3200 \mathrm{X}$, same specimen as Figure 17.

16: Cross-polarized light, $3200 \mathrm{X}$, same specimen as Figure 17.

17: Scanning electron micrograph of the distal side, $6500 \times$.

18: Scanning electron micrograph of the distal side, $60^{\circ}$ inclined, $6500 \mathrm{X}$, same specimen as Figure 17. 


\section{PLATE 6}
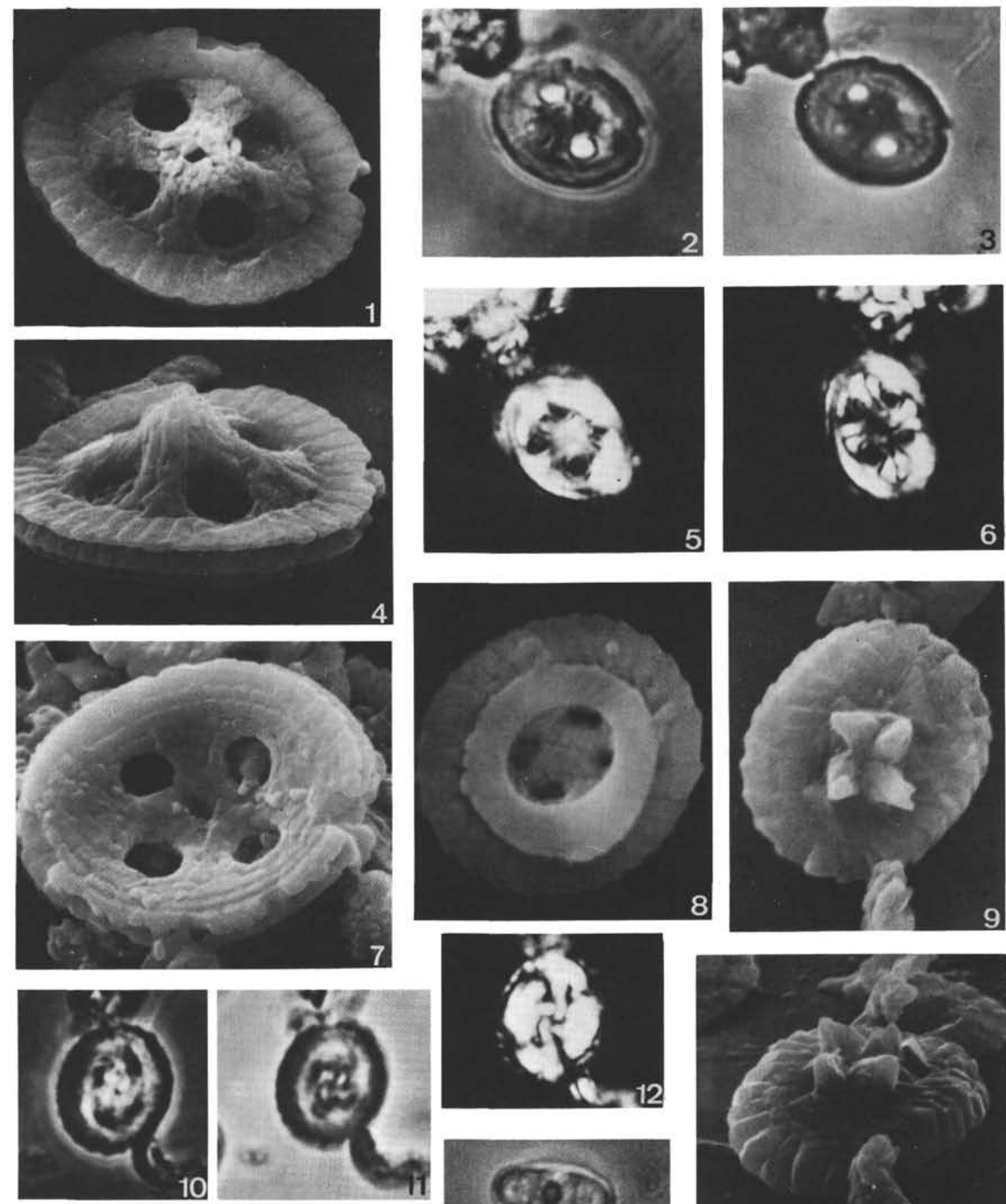

8
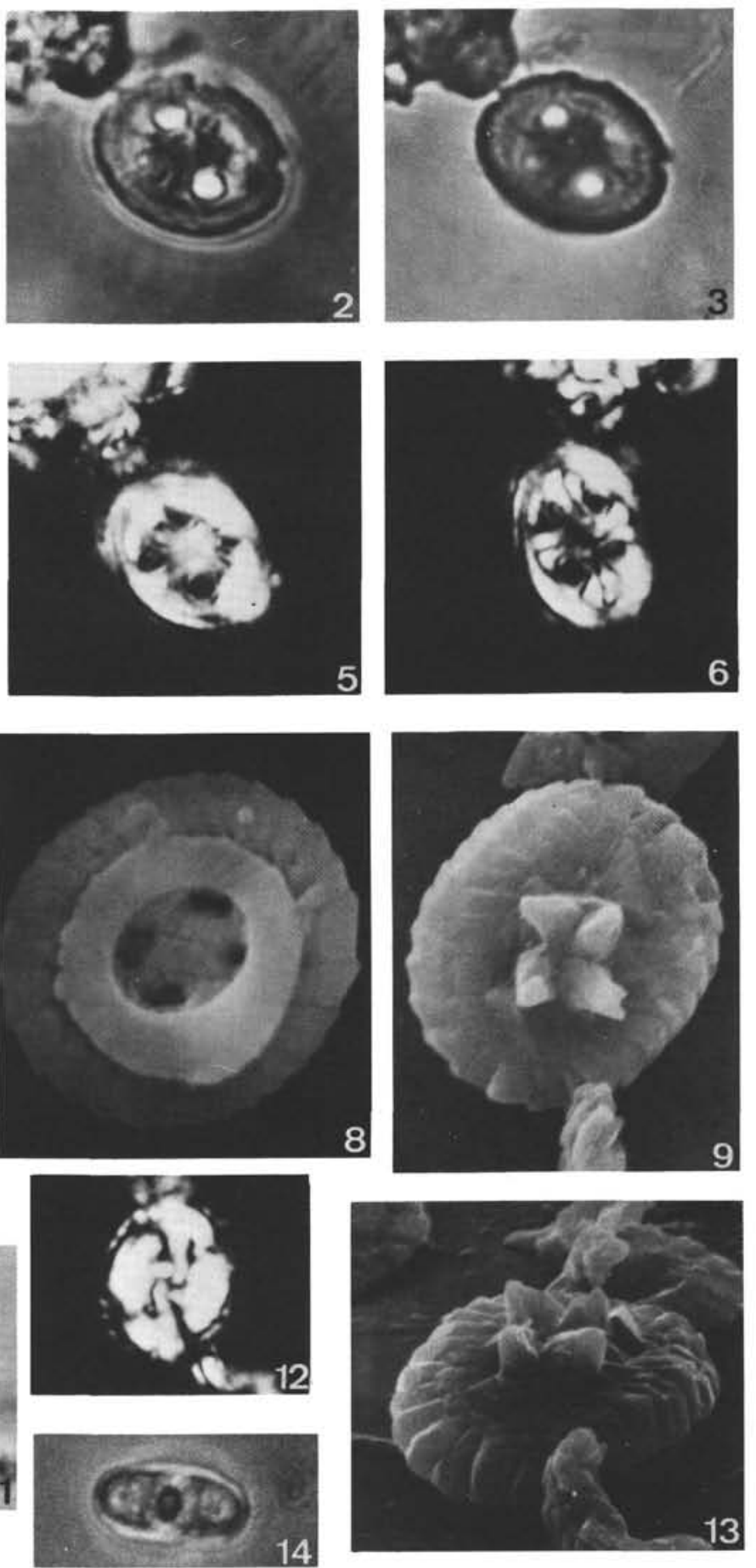

\section{3}

6
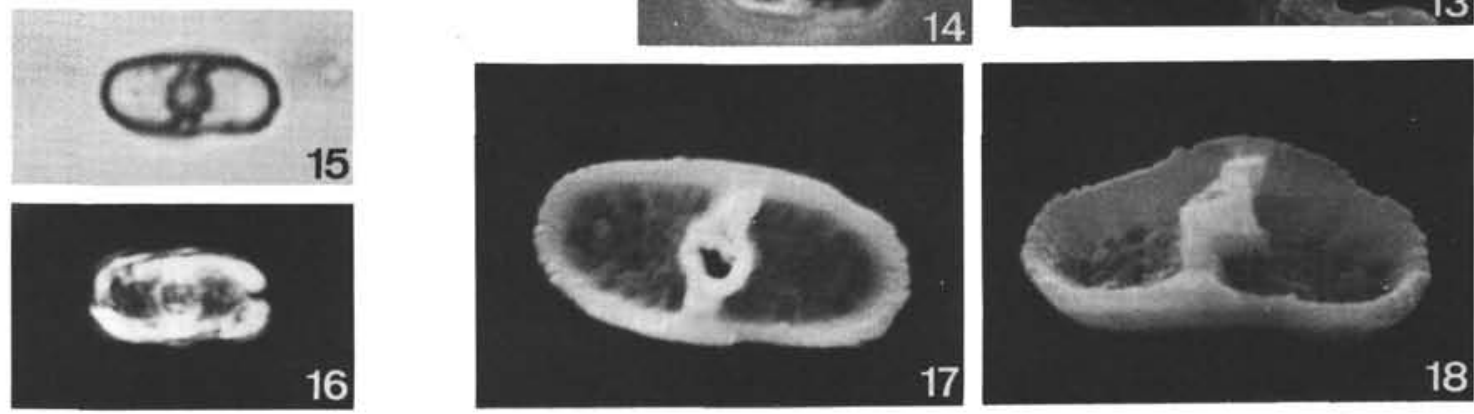


\section{PLATE 7}

Figure 1: $\quad$ Parhabdolithus angustus (Stradner, 1963) Stradner, 1968

Scanning electron micrograph of the proximal side, $6500 \times$, Leg 14-144A-5-1, 125-127 cm.

Figures 2-6

Parhabdolithus splendens (Deflandre, 1954) Noel, 1969 Leg 14-144A-5-1, 125-127 cm.

2: Phase contrast, $3200 \mathrm{X}$, same specimen as Figure 6.

3: Transmitted light, $3200 \times$, same specimen as Figure 6 ,

4: Cross-polarized light, $3200 \times$, same specimen as Figure 6.

5: Scanning electron micrograph of the proximal side, $6500 \times$.

6: Scanning electron micrograph of the distal side, $6500 \times$.

Figures 7-17 Parhabdolithus asper (Stradner, 1963) Reinhardt, 1967

7: Scanning electron micrograph of the distal side, $6500 \times$, Leg 14-135-9-2, $21-23 \mathrm{~cm}$.

8: Scanning electron micrograph of the distal side, $6500 \times$, Leg 14-135-9-2, $21-23 \mathrm{~cm}$.

9: Phase contrast, $3200 \times$, same specimen as Figure 8.

10: Transmitted light, $3200 \mathrm{X}$, same specimen as Figure 8 .

11: Cross-polarized light, $3200 \mathrm{X}$, same specimen as Figure 8.

12: Scanning electron micrograph of the distal side, $6500 \times$, Leg 14-135-9-2, $21-23 \mathrm{~cm}$.

13: Scanning electron micrograph of the distal side, $6500 \times$, Leg 14-135-9-2, $21-23 \mathrm{~cm}$.

14: Scanning electron micrograph of the proximal side, $6500 \times$, Leg 14-135-9-2, $69-71 \mathrm{~cm}$.

15: Phase contrast, $3200 \mathrm{X}$, same specimen as Figure 14.

16: Transmitted light, $3200 \mathrm{X}$, same specimen as Figure 14.

17: Cross-polarized light, $3200 \mathrm{X}$, same specimen as Figure 14. 
PLATE 7
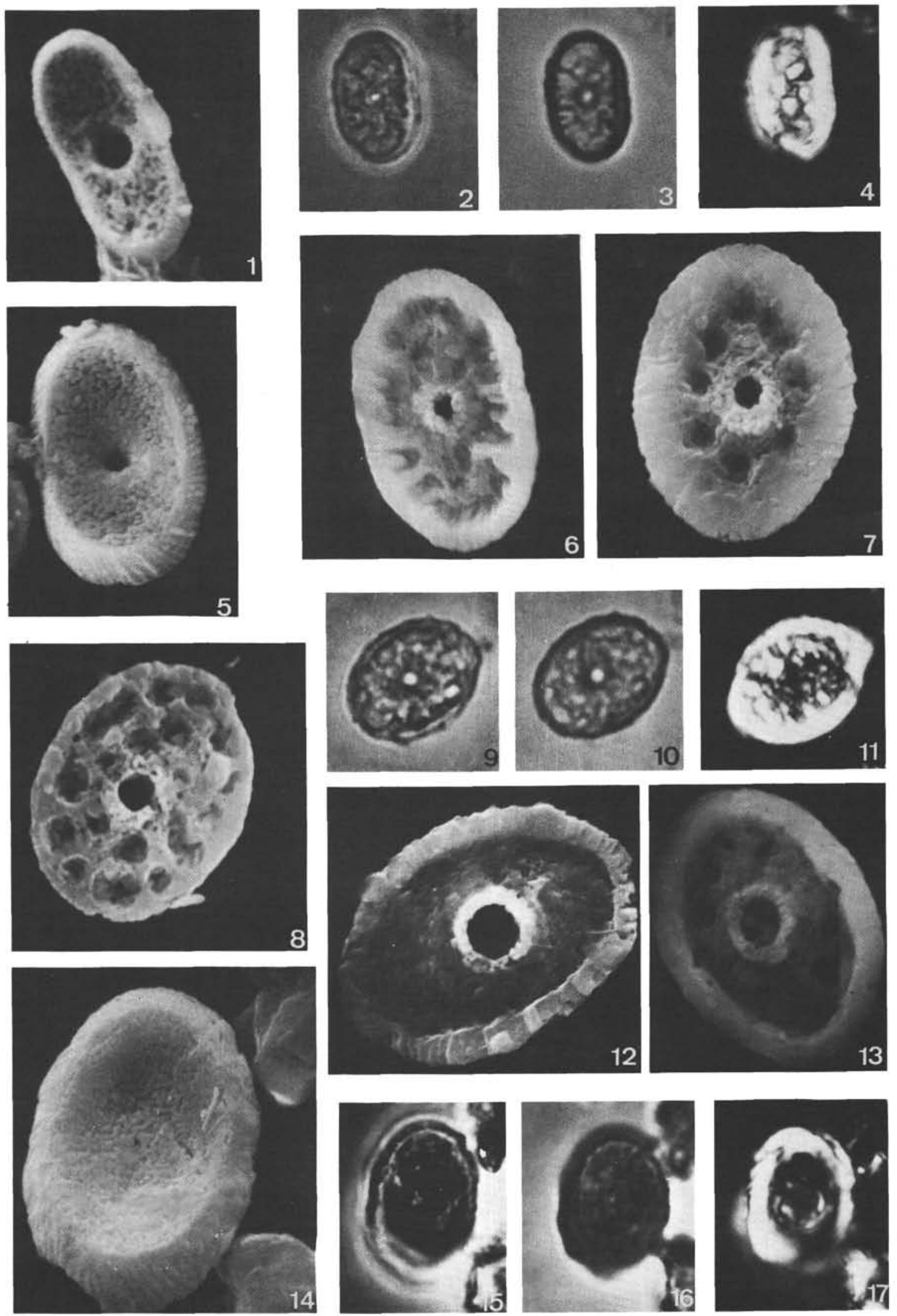


\section{PLATE 8}

Figures 1-12 Reinhardtites fenestratus (Worsley, 1971) Thierstein n. comb. Leg 14-135-9-2, 21-23 cm.

1: Scanning electron micrograph of the proximal side, $6500 \times$, hypotype [4379] A932.

2: Phase contrast, $3200 \mathrm{X}$, same specimen as Figure 1.

3: Transmitted light, $3200 \times$, same specimen as Figure 1.

4: Scanning electron micrograph of the proximal side, $60^{\circ}$ inclined, $6500 \mathrm{X}$, same specimen as Figure 1.

5: Cross-polarized light, $3200 \mathrm{X}$, same specimen as Figure 1.

6: Cross-polarized light, $3200 \mathrm{X}$, same specimen as Figure 1.

7: Scanning electron micrograph of the distal side, $6500 \times$.

8: Scanning electron micrograph of the proximal side, $6500 \times$.

9: Scanning electron micrograph of the distal side, $6500 \times$, hypotype [4383] A933.

10: Phase contrast, $3200 \mathrm{X}$, same specimen as Figure 7.

11: Transmitted light, $3200 \mathrm{X}$, same specimen as Figure 7.

12: Cross-polarized light, $3200 \times$, same specimen as Figure 7.

Figures 13-18 Biscutum constans (Gorka, 1957) Black, 1959

13: Scanning electron micrograph of the proximal side, 13,000 X, Leg 14-137-14-2, 132-134 cm.

14: Scanning electron micrograph of the distal side, 13,000 X, Leg 14-144-4-1, top.

15: Phase contrast, $3200 \mathrm{X}$, same specimen as Figure 13.

16: Transmitted light, $3200 \mathrm{X}$, same specimen as Figure 13.

17: Cross-polarized light, $3200 \times$, same specimen as Figure 13.

18: Scanning electron micrograph of the proximal side, 13,000 X, Leg 14-137-14-2, 132-134 cm. 
PLATE 8
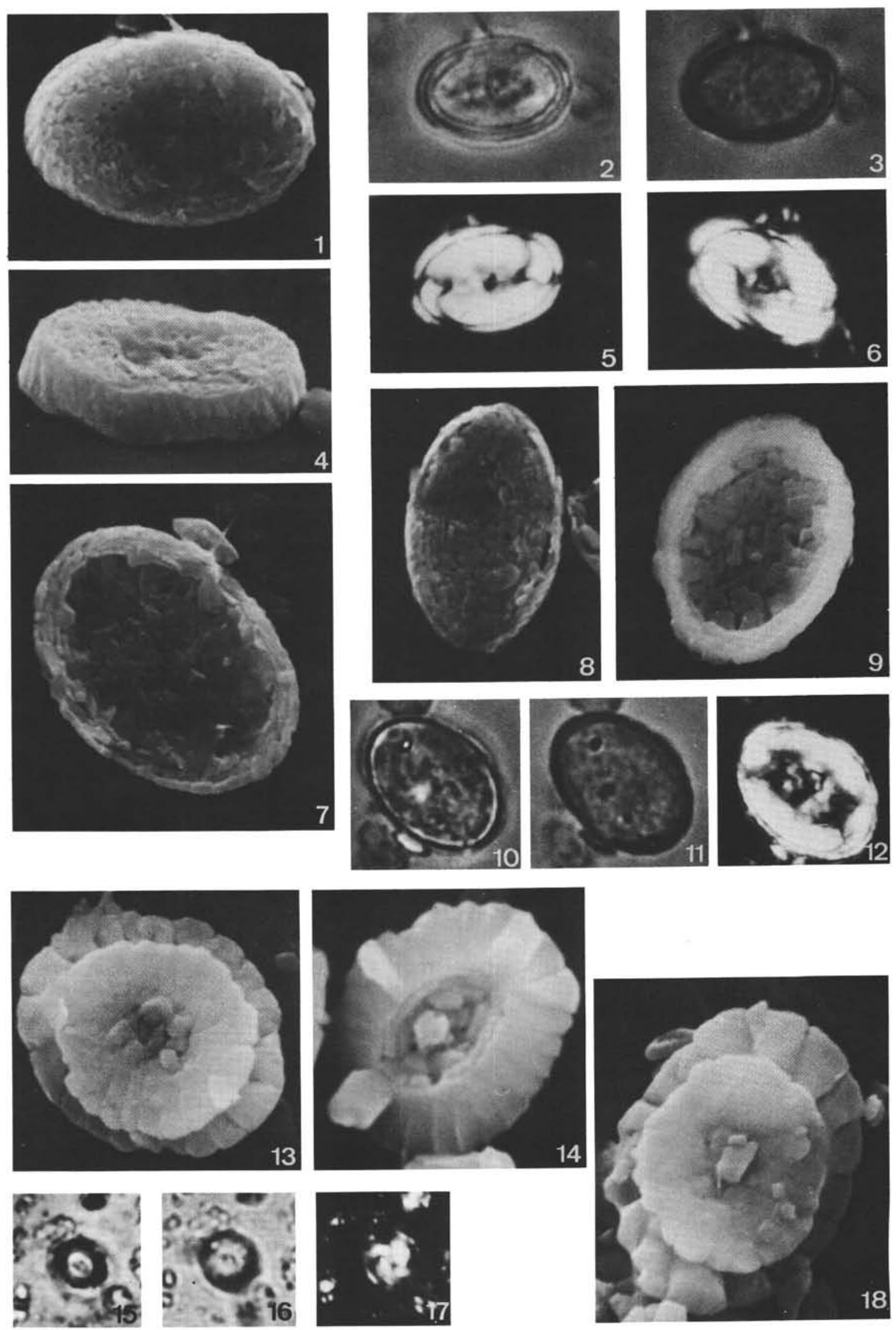


\section{PLATE 9}

Figures 1-6 Parhabdolithus embergeri (Noel, 1959) Stradner, 1963 Leg 14-137-14-2, $132-134 \mathrm{~cm}$.

1: Scanning electron micrograph of the proximal side, $4500 \mathrm{X}$.

2: Phase contrast, $3200 \mathrm{X}$, same specimen as Figure 1.

3: Transmitted light, $3200 \mathrm{X}$, same specimen as Figure 1.

4: Cross-polarized light, $3200 \mathrm{X}$, same specimen as Figure 1.

5: Cross-polarized light, $3200 \times$, same specimen as Figure 1.

6: Scanning electron micrograph of the distal side, $3200 \times$.

Figures 7-16 Parhabdolithus infinitus (Worsley, 1971) Theirstein n. comb. Leg A4-A35-g-2, 24-23 cm.

7: Scanning electron micrograph of the distal side, $5000 \times$, hypotype [4330] A934.

8: Phase contrast, $3200 X$, same specimen as Figure 7.

9: Transmitted light, $3200 \mathrm{X}$, same specimen as Figure 7.

10: Cross-polarized light, $3200 \times$, same specimen as Figure 7.

11: Scanning electron micrograph of the distal side, $3200 \times$.

12: Phase contrast, $3200 \times$, same specimen as Figure 13.

13: Scanning electron micrograph of the proximal side, $6500 \times$, hypotype [4364] A935.

14: Transmitted light, $3200 \times$, same specimen as Figure 13.

15: Cross-polarized light, $3200 \mathrm{X}$, same specimen as Figure 13.

16: Cross-polarized light, $3200 \times$, low focus, same specimen as Figure 13. 


\section{PLATE 9}
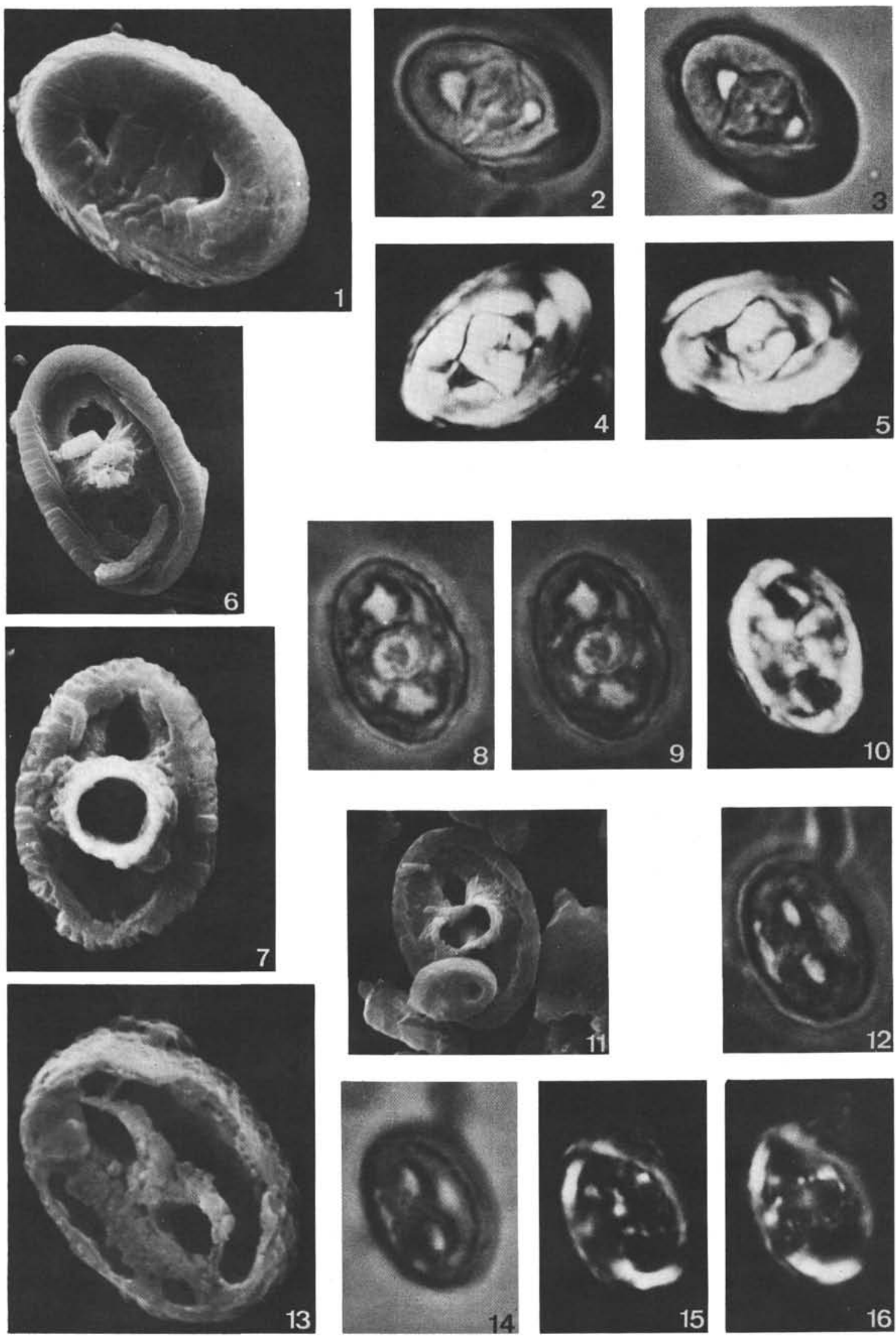


\section{PLATE 10}

Figures 1-5 Tranolithus gabalus Stover, 1966 Leg 14-137-14-2, $132-134 \mathrm{~cm}$.

1: Scanning electron micrograph of the proximal side, $13,000 \times$.

2: Phase contrast, $3200 \times$, same specimen as Figure 1.

3: Scanning electron micrograph of the distal side, $13,000 \times$

4: Transmitted light, $3200 \times$, same specimen as Figure 1.

5: Cross-polarized light, $3200 \times$, same specimen as Figure 1.

Figures 6-10

Tranolithus exiguus Stover, 1966, Leg 14-137-14-2, $132-134 \mathrm{~cm}$.

6: Scanning electron micrograph of the distal side, $6500 \times$.

7: Scanning electron micrograph of the proximal side, $6500 \times$.

8: Phase contrast, $3200 \times$, same specimen as Figure 7.

9: Transmitted light, $3200 \mathrm{X}$, same specimen as Figure 7.

10: Cross-polarized light, $3200 \times$, same specimen as Figure 7.

Figures 11-15 Tranolithus orionatus (Reinhardt, 1966) Reinhardt, 1966, Leg 14-144-4-1, top.

11: Scanning electron micrograph of the proximal side, $6500 \times$.

12: Scanning electron micrograph of the distal side, $7500 \times$.

13: Phase contrast, $3200 \times$, same specimen as Figure 12.

14: Transmitted light, $3200 \mathrm{X}$, same specimen as Figure 12.

15: Cross-polarized light, $3200 \mathrm{X}$, same specimen as Figure 12.

Figures 16-20 Glaukolithus elegans (Gartner, 1968 emend. Bukry, 1969) Thierstein n. comb. Leg 14-137-14-2, 132-134

$\mathrm{cm}$.

16: Scanning electron micrograph of the distal side, $45^{\circ}$ inclined, $6500 \mathrm{X}$, same specimen as Figure 17.

17: Scanning electron micrograph of the distal side, $6500 \times$.

18: Phase contrast, $3200 \mathrm{X}$, same specimen as Figure 17.

19: Transmitted light, $3200 \times$, same specimen as Figure 17.

20: Cross-polarized light, $3200 \times$, same specimen as Figure 17. 
PLATE 10
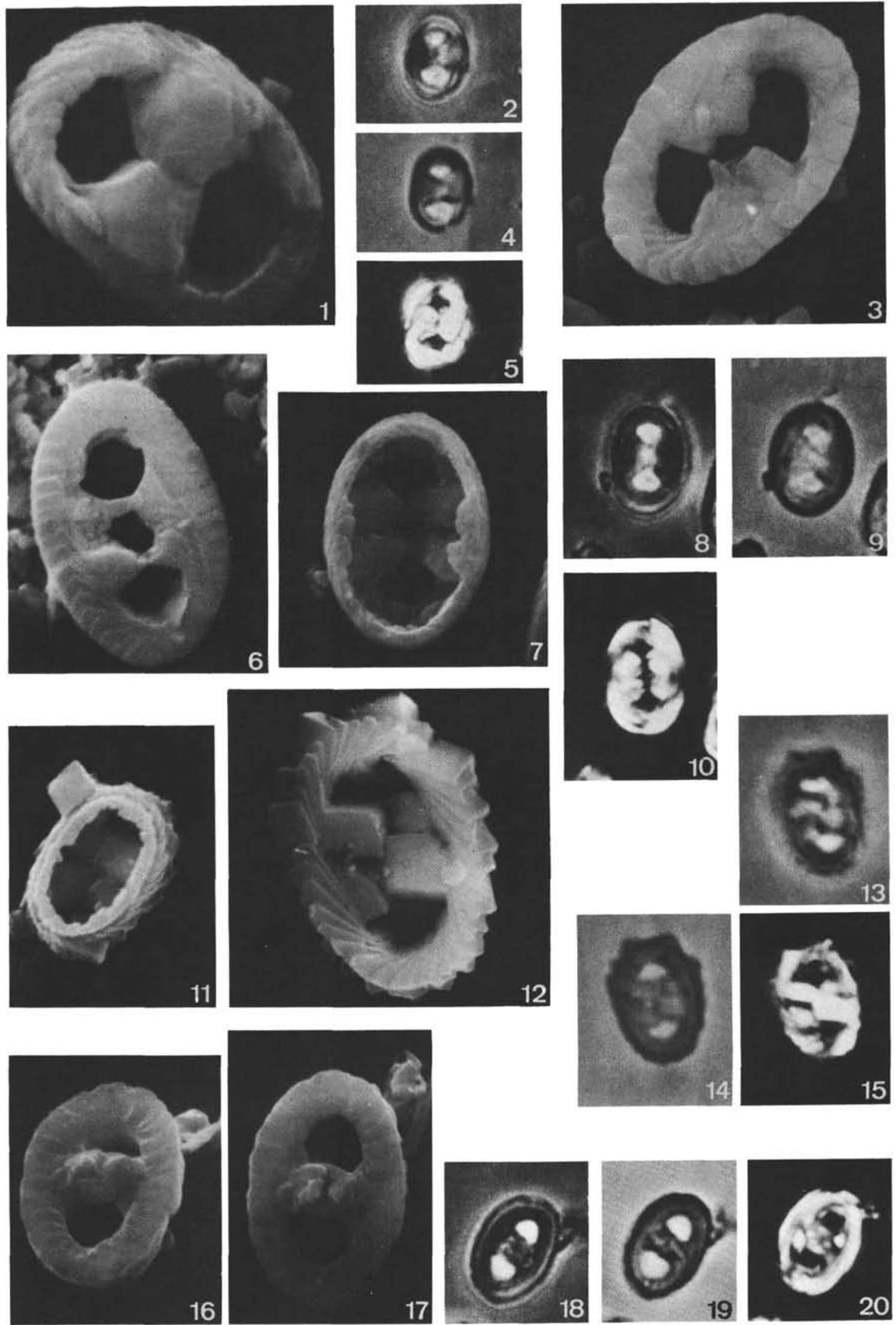

12
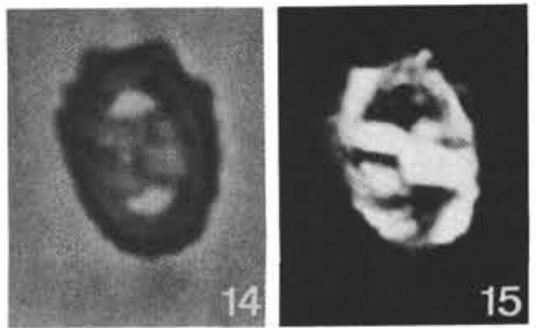

17
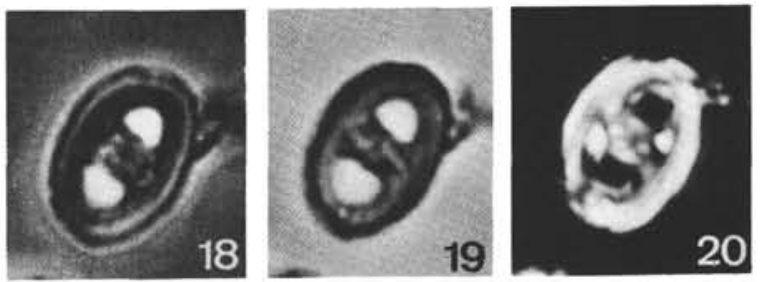


\section{PLATE 11}

Figures 1-5 Glaukolithus diplogrammus (Deflandre, 1954) Reinhardt, 1964 Leg 14-137-14-2, 132-134 cm.

1: Scanning electron micrograph of the proximal side, $6500 \times$.

2: Scanning electron micrograph of the distal side, $6500 \times$.

3: Phase contrast, $3200 \times$, same specimen as Figure 2.

4: Transmitted light, $3200 \mathrm{X}$, same specimen as Figure 2.

5: Cross-polarized light, $3200 \mathrm{X}$, same specimen as Figure 2.

Figures 6-13 Manivitella pemmatoidea (Deflandre ex Manivit, 1965) Thierstein, 1971 Leg 14-137-14-2, 132-134 cm.

6: Scanning electron micrograph of the distal side, $3200 \times$.

7: Phase contrast, $3200 \times$, same specimen as Figure 6.

8: Transmitted light, $3200 \times$, same specimen as Figure 6.

9: Cross-polarized light, $3200 \mathrm{X}$, same specimen as Figure 6.

10: Scanning electron micrograph of the proximal side, $3500 \times$.

11: Phase contrast, $3200 \times$, same specimen as Figure 10.

12: Transmitted light, $3200 \mathrm{X}$, same specimen as Figure 10.

13: Cross-polarized light, $3200 \times$, same specimen as Figure 10. 
PLATE 11
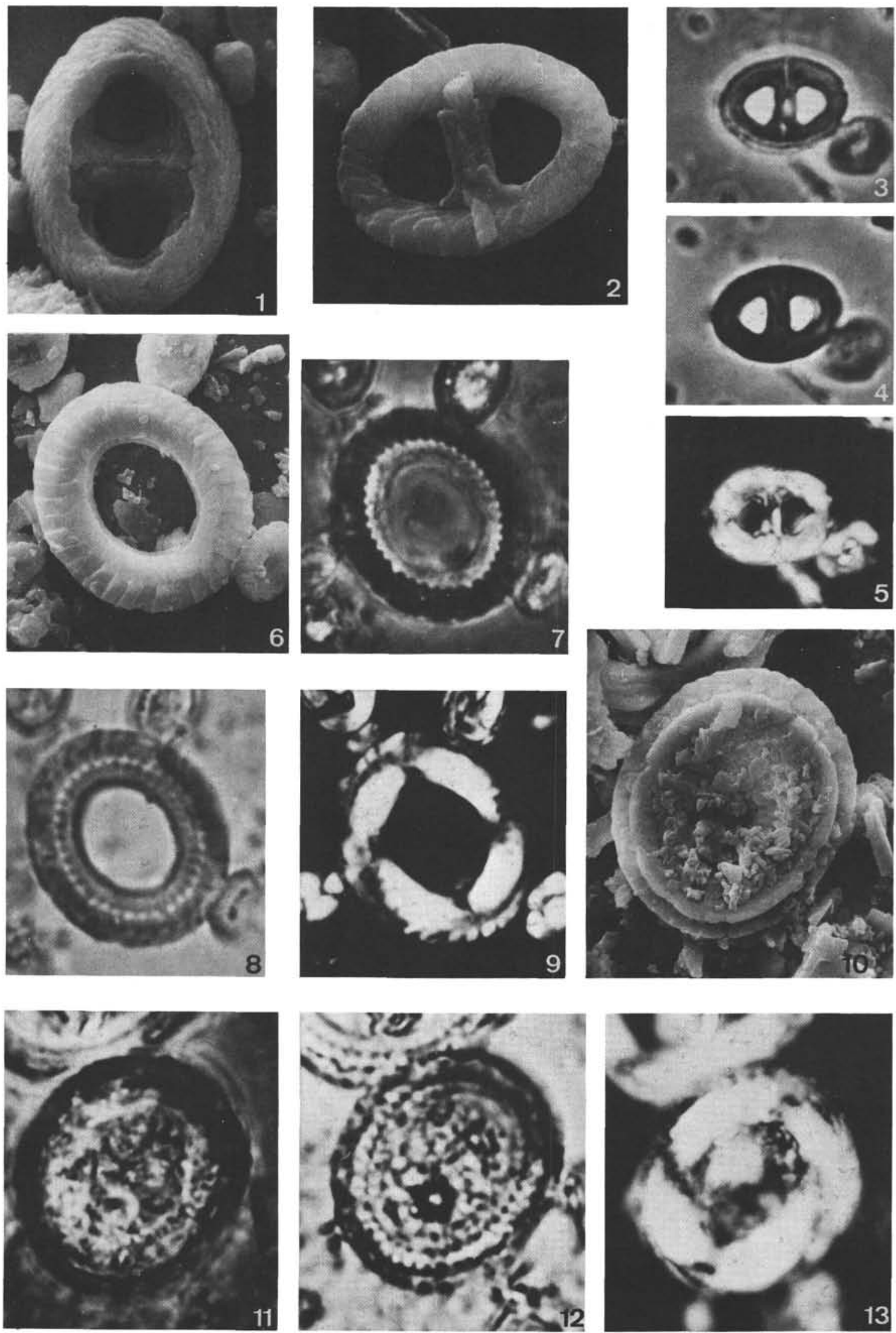


\section{PLATE 12}

Figures 1-6 Chiastozygus cuneatus (Lyul'eva, 1967) Cepek and Hay, 1969 Leg 14-144A-5-1, 125-127 cm.

1: Scanning electron micrograph of the proximal side, $6500 \mathrm{X}$.

2: Scanning electron micrograph of the distal side, $6500 \mathrm{X}$.

3: Phase contrast, $3200 \times$, same specimen as Figure 2.

4: Transmitted light, $3200 \times$ same specimen as Figure 2.

5: Cross-polarized light, $3200 \times$, same specimen as Figure 2.

6: Cross-polarized light, $3200 \times$, same specimen as Figure 2.

Figures 7-18 Eiffellithus trabeculatus (Gorka, 1957) Reinhardt and Gorka, 1967

7: Scanning electron micrograph of the distal side, $6500 \times$, Leg 14-1.37-14-2, $132-134 \mathrm{~cm}$.

8: Phase contrast, $3200 \times$, same specimen as Figure 7.

9: Transmitted light, $3200 \mathrm{X}$, same specimen as Figure 7.

10: Scanning electron micrograph of the proximal side, $6500 \times$, Leg 14-137-14-2, 132-134 cm.

11: Cross-polarized light, $3200 \times$, same specimen as Figure 7.

12: Cross-polarized light, $3200 \times$, same specimen as Figure 7.

13: Scanning electron micrograph of the proximal side, $6500 \times, 45^{\circ}$ inclined, same specimen as Figure 10.

14: Scanning electron micrograph of the distal side, $6500 \mathrm{X}$, Leg 14-144-4-1, top.

15: Phase contrast, $3200 \mathrm{X}$, same specimen as Figure 14.

16: Transmitted light, $3200 \mathrm{X}$, same specimen as Figure 14.

17: Cross-polarized light, $3200 \mathrm{X}$, same specimen as Figure 14.

18: Cross-polarized light, $3200 \mathrm{X}$, same specimen as Figure 14.

Figures 19-22 Cylindralithus asymmetricus Bukry, 1969 Leg 14-144-4-1, top

19: Scanning electron micrograph of the distal side, $12,000 \times$.

20: Phase contrast, $3200 \times$, same specimen as Figure 19.

21: Transmitted light, $3200 \times$, same specimen as Figure 19.

22: Cross-polarized light, $3200 \mathrm{X}$, same specimen as Figure 19.

Figures 23-26 Cylindralithus coronatus Bukry, 1969 Leg 14-144A-5-1, 125-127 cm.

23: Scanning electron micrograph of the proximal side, $45^{\circ}$ inclined, $6500 \times$.

24: Phase contrast, $3200 \times$, same specimen as Figure 23.

25: Transmitted light, $3200 \mathrm{X}$, same specimen as Figure 23.

26: Cross-polarized light, $3200 \mathrm{X}$, same specimen as Figure 23. 
PLATE 12
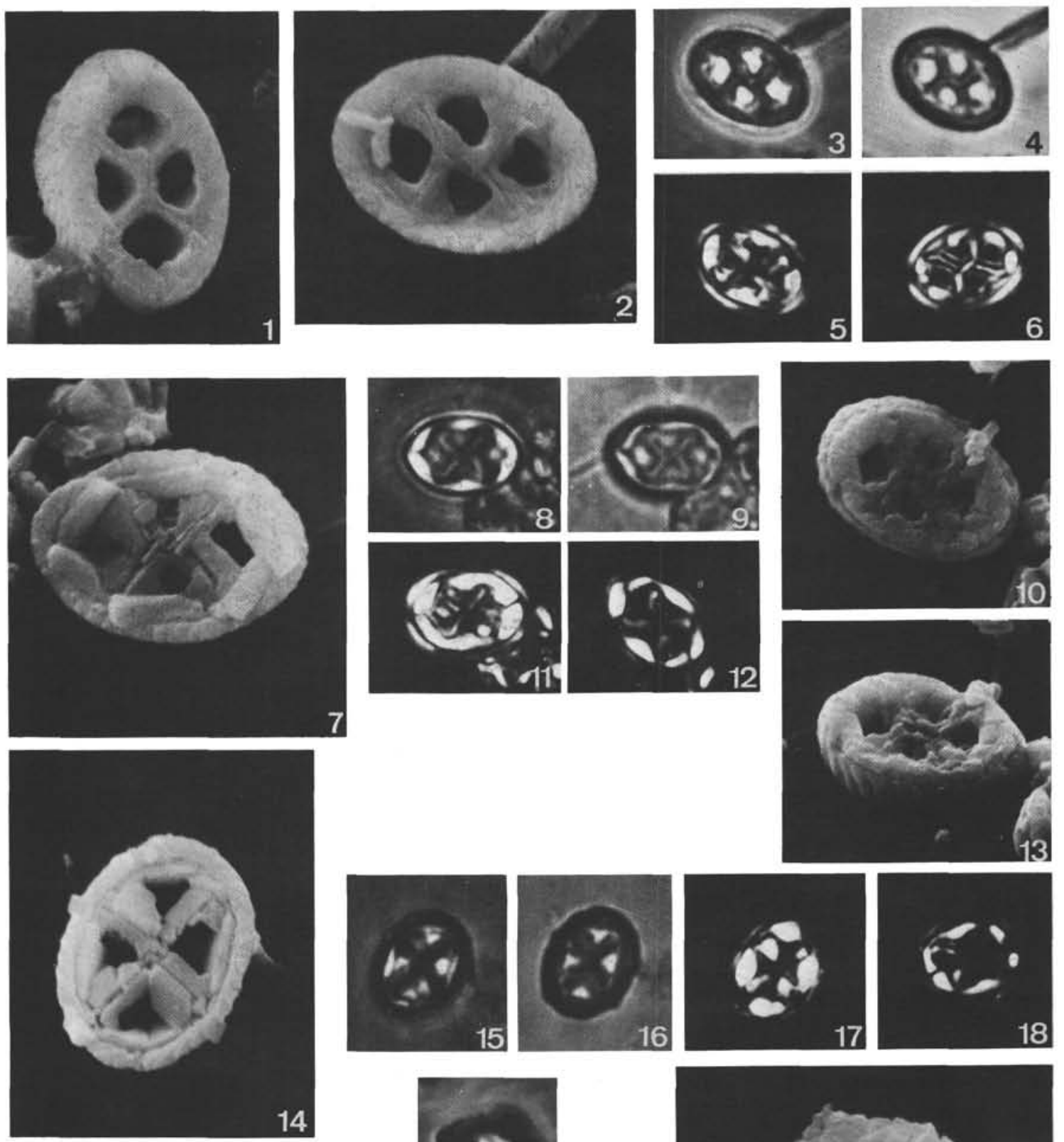

14
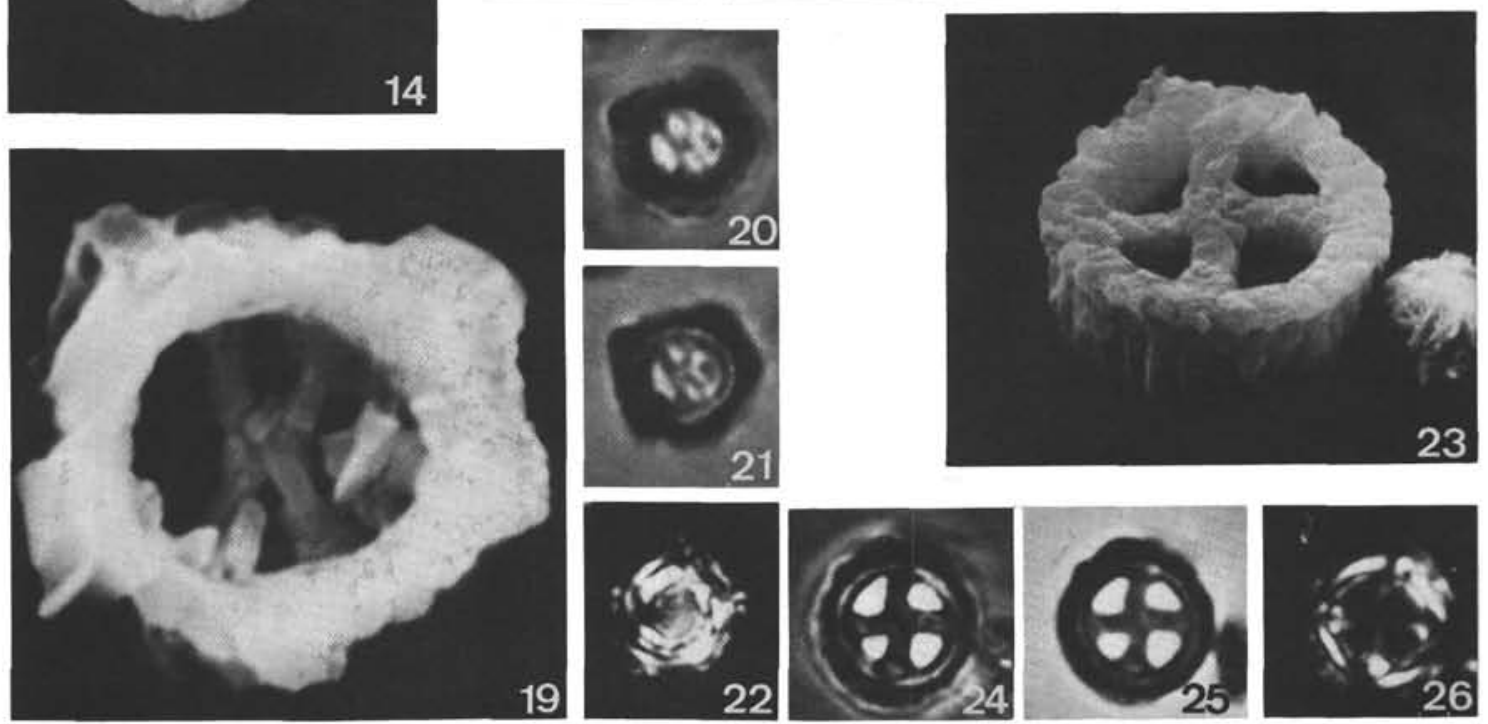


\section{PLATE 13}

Figures 1.5 Cylindralithus coronatus Bukry, 1969 Leg 14-144A$5-1,125-127 \mathrm{~cm}$.

1: Scanning electron micrograph of the distal side, $50^{\circ}$ inclined, $7000 \times$, same specimen as Figure 2.

2: Scanning electron micrograph of the distal side, $6500 \times$.

3: Phase contrast, $3200 \times$, same specimen as Figure 2.

4: Transmitted light, $3200 \mathrm{X}$, same specimen as Figure 2.

5: Cross-polarized light, $3200 \times$, same specimen as Figure 2.

Figures 6-11 Staurolithites matalosus (Stover, 1966) Cepek and Hay, 1969 Leg 14-137-14-2, 132-134 cm.

6: Scanning electron micrograph of the distal side, $60^{\circ}$ inclined, $6500 \times$, same specimen as Figure 7.

7: Scanning electron micrograph of the distal side, $6500 \times$.

8: Phase contrast, $3200 \times$, same specimen as Figure 7.

9: Transmitted light, $3200 \mathrm{X}$, same specimen as Figure 7.

10: Cross-polarized light, $3200 \mathrm{X}$, same specimen as Figure 7.

11: Cross-polarized light, $3200 \mathrm{X}$, same specimen as Figure 7.

Figures 12-20 Broinsonia signata (Noel, 1969) Noel, 1970 Leg $14-137-14-2,132-134 \mathrm{~cm}$.

12: Scanning electron micrograph of the distal side, $6500 \times$.

13: Phase contrast, $3200 \mathrm{X}$, same specimen as Figure 12.

14: Transmitted light, $3200 \mathrm{X}$, same specimen as Figure 12.

15: Cross-polarized light, $3200 \times$, same specimen as Figure 12.

16: Cross-polarized light, $3200 \mathrm{X}$, same specimen as Figure 12.

17: Scanning electron micrograph of the distal side, $50^{\circ}$ inclined, $6500 \mathrm{X}$.

18: Phase contrast, $3200 \times$, same specimen as Figure 17.

19: Transmitted light, $3200 \mathrm{X}$, same specimen as Figure 17.

20: Cross-polarized light, $3200 \mathrm{X}$, same specimen as Figure 17. 
PLATE 13
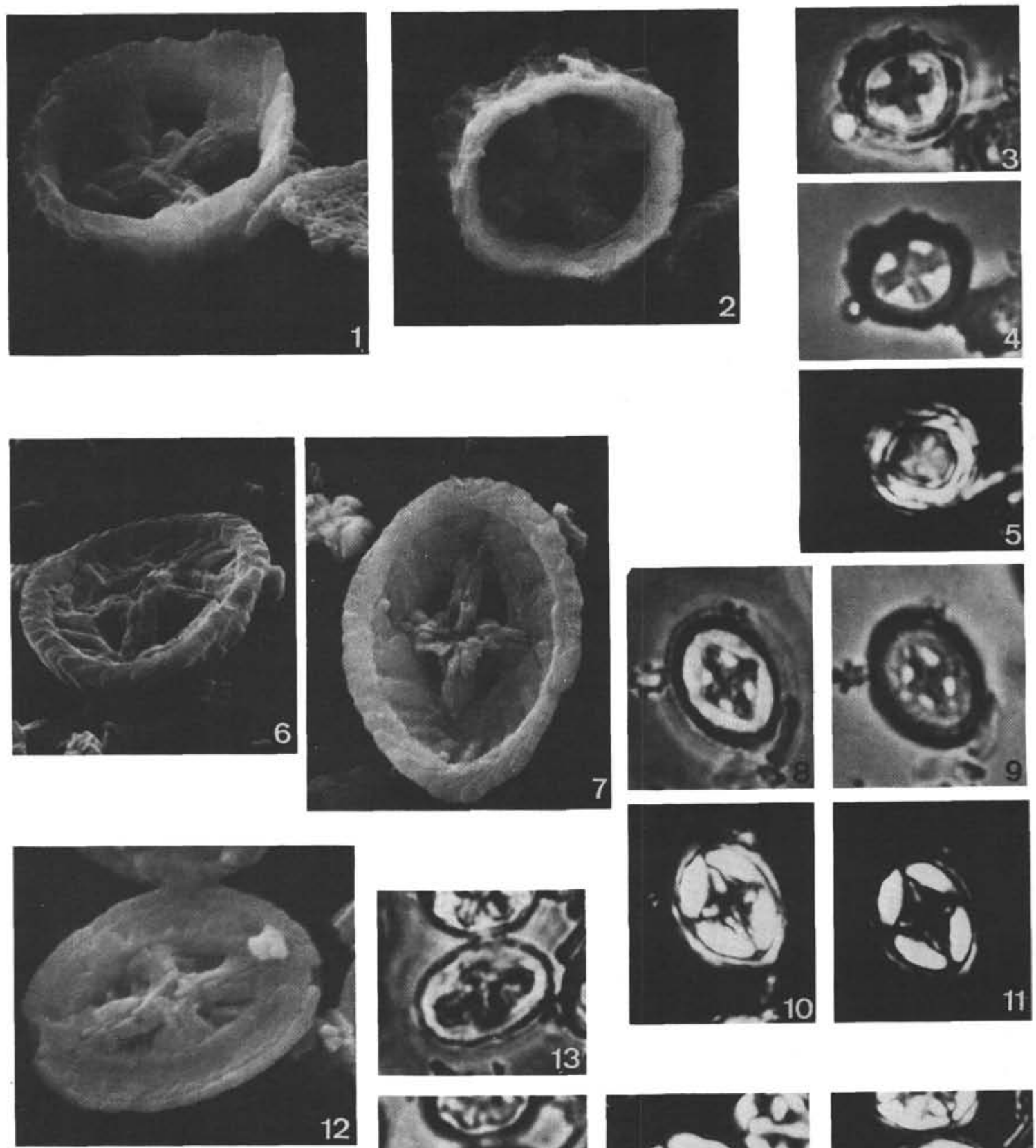

12
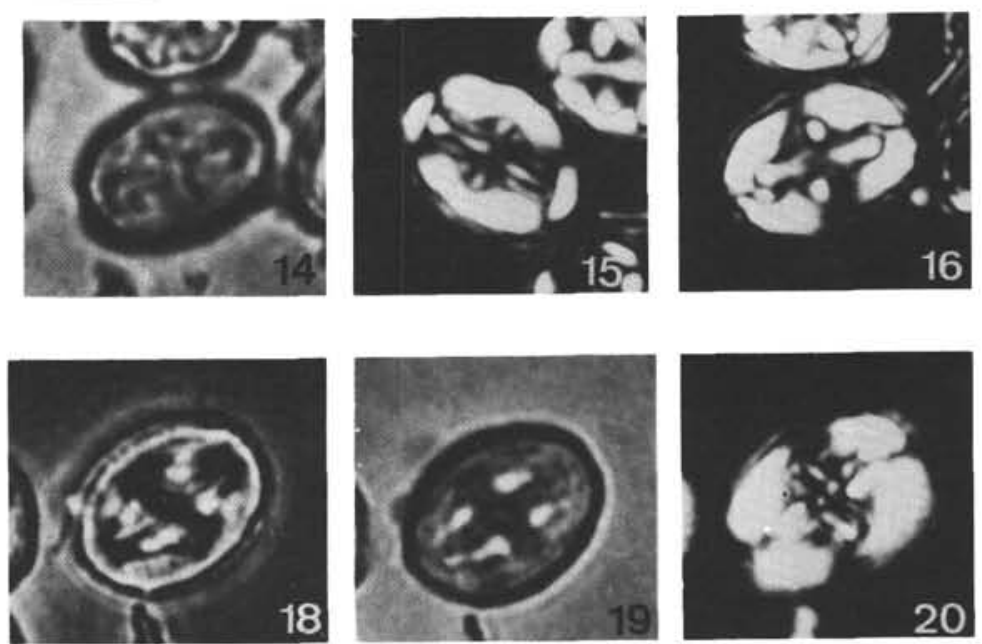


\section{PLATE 14}

Figures 1-5 Broinsonia signata (Noel, 1969) Noel, 1970 Leg 14-144-4-1, top.

1: Scanning electron micrograph of the proximal side, $8000 \mathrm{X}$.

2: Phase contrast, $3200 \mathrm{X}$, same specimen as Figure 1.

3: Transmitted light, $3200 \mathrm{X}$, same specimen as Figure 1.

4: Cross-polarized light, $3200 \times$, same specimen as Figure 1.

5: Cross-polarized light, $3200 \times$, same specimen as Figure 1.

Figures 6-13 Broinsonia dentata Bukry, 1969 Leg 14-144A-5-1, 125-127 cm.

6: Phase contrast, $3200 \times$, same specimen as Figure 9.

7: Transmitted light, $3200 \mathrm{X}$, same specimen as Figure 9.

8: Cross-polarized light, $3200 \times$, same specimen as Figure 9.

9: Scanning electron micrograph of the distal side, $6500 \mathrm{X}$.

10: Phase contrast, $3200 \times$, same specimen as Figure 13.

11: Transmitted light, $3200 \times$, same specimen as Figure 13.

12: Cross-polarized light, $3200 \mathrm{X}$, same specimen as Figure 13.

13: Scanning electron micrograph of the proximal side, $6500 \mathrm{X}$.

Figures 14-17, Broinsonia bevieri Bukry, 1969 Leg 14-144-4-1, top. 22-29

14: Phase contrast, $3200 \times$, same specimen as Figure 17.

15: Transmitted light, $3200 \mathrm{X}$, same specimen as Figure 17.

16: Cross-polarized light, $3200 \times$, same specimen as Figure 17.

17: Scanning electron micrograph of the proximal side, $12,000 \mathrm{X}$.

22: Scanning electron micrograph of the distal side, $7500 \mathrm{X}$.

23: Phase contrast, $3200 \mathrm{X}$, same specimen as Figure 22.

24: Transmitted light, $3200 \mathrm{X}$, same specimen as Figure 22.

25: Cross-polarized light, $3200 \mathrm{X}$, same specimen as Figure 22.

26: Phase contrast, $3200 \times$, same specimen as Figure 29.

27: Transmitted light, $3200 \mathrm{X}$, same specimen as Figure 29.

28: Cross-polarized light, $3200 \times$, same specimen as Figure 29.

29: Scanning electron micrograph of the proximal side, $6500 \times$.

Figures 18-21 Broinsonia lata (Noel, 1969) Noel, 1970 Leg 14-137-14-2, 132-134 cm.

18: Scanning electron micrograph of the distal side, $6500 \mathrm{X}$.

19: Phase contrast, $3200 \mathrm{X}$, same specimen as Figure 18.

20: Transmitted light, $3200 \times$, same specimen as Figure 18.

21: Cross-polarized light, $3200 \mathrm{X}$, same specimen as Figure 18. 
PLATE 14
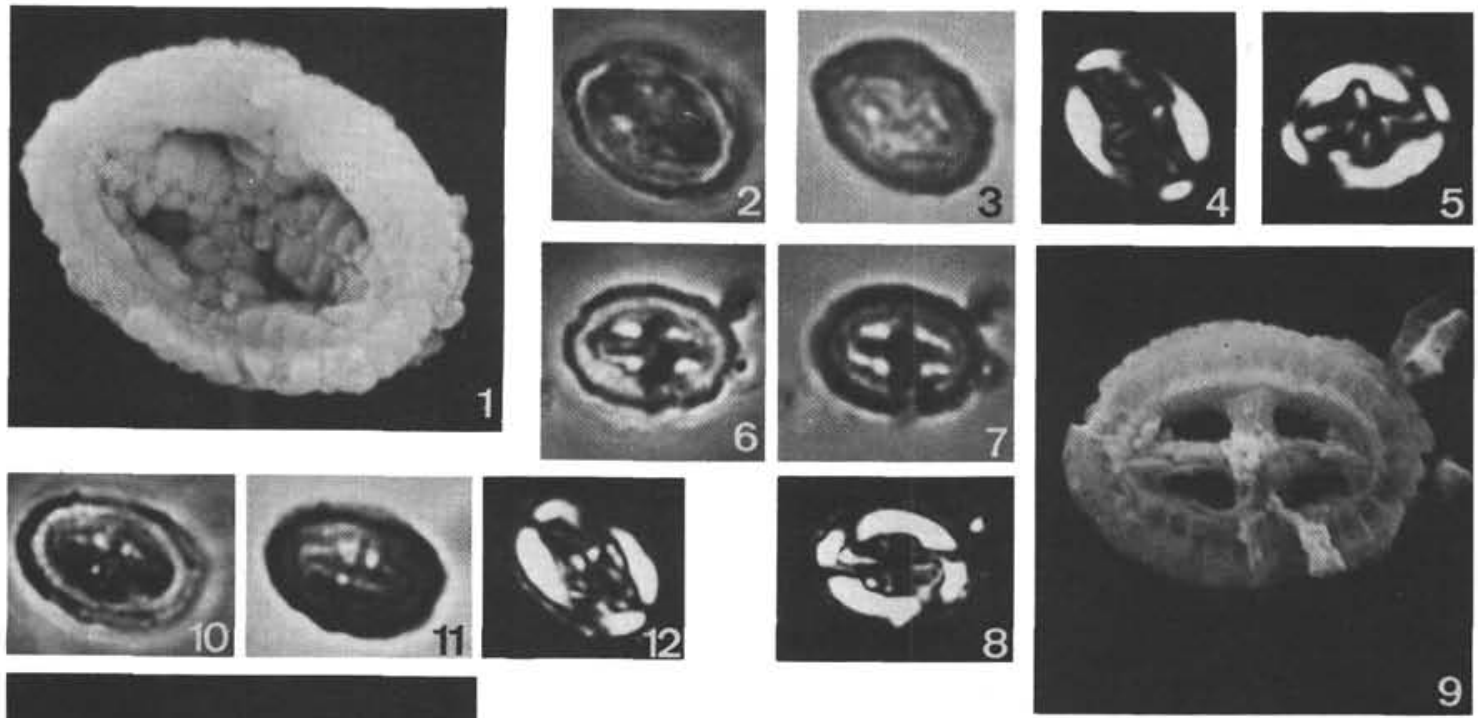

9
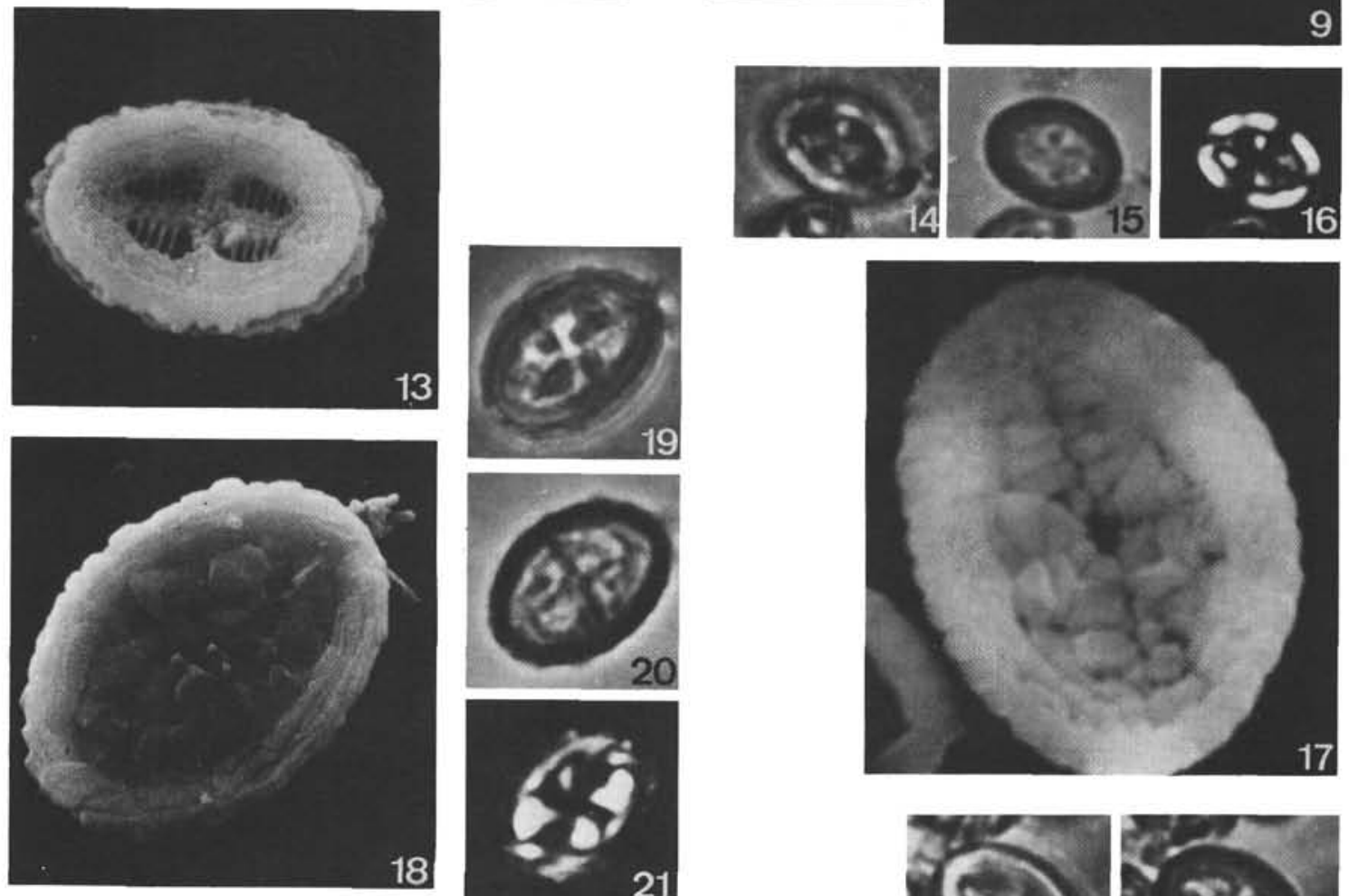

19
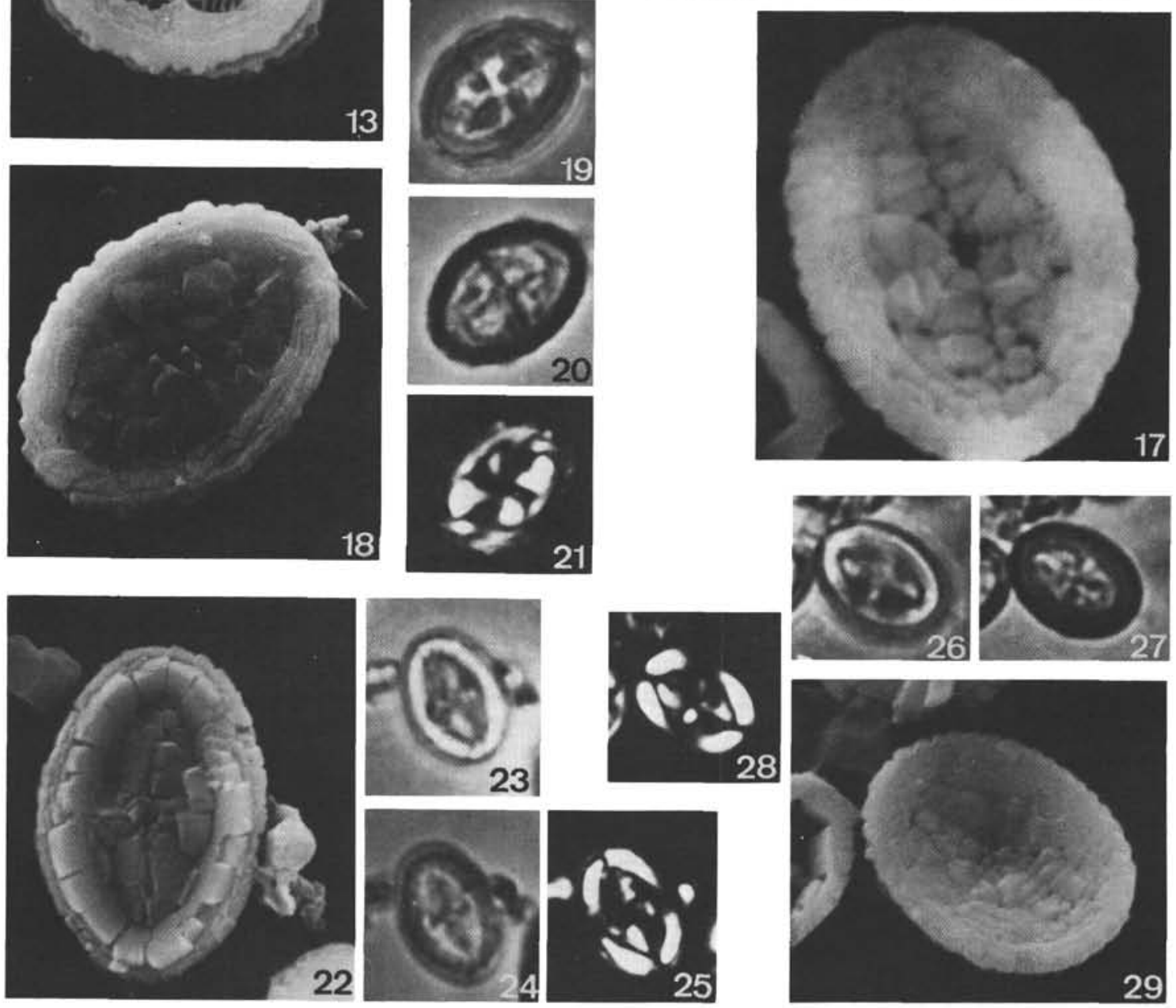


\section{PLATE 15}

Figures $1-8$

Figures 9-15

Broinsonia orthocancellata Bukry, 1969 Leg 14-144A-5-1, $125-127 \mathrm{~cm}$.

1: Scanning electron micrograph of the proximal sides, $6500 \mathrm{X}$.

2: Phase contrast, $3200 \times$, same specimens as Figure 1.

3: Transmitted light, $3200 \times$, same specimens as Figure 1.

4: Cross-polarized light, $3200 \times$, same specimens as Figure 1.

5: Phase contrast, $3200 \times$, same specimen as Figure 8.

6: Transmitted light, $3200 \mathrm{X}$, same specimen as Figure 8.

7: Cross-polarized light, $3200 \mathrm{X}$, same specimen as Figure 8.

8: Scanning electron micrograph of the distal side, $6500 \times$.

Gartnerago diversum Thierstein n. sp. Leg 14-144A$5-1,125-127 \mathrm{~cm}$.

9: Scanning electron micrograph of the proximal side, $4500 \times$, holotype [4235] A928.

10: Scanning electron micrograph of the distal side, $4500 \times$, paratype [4251] A929.

11: Phase contrast, $3200 \mathrm{X}$, same specimen as Figure 9.

12: Scanning electron micrograph of the proximal side, $35^{\circ}$ inclined, $6500 \mathrm{X}$, same specimen as Figure 9.

13: Scanning electron micrograph of the proximal side, $6500 \times$, paratype [4258] A930.

14: Transmitted light, $3200 \mathrm{X}$, same specimen as Figure 9.

15: Cross-polarized light, $3200 \mathrm{X}$, same specimen as Figure 9.

Figures 16-19 Prediscosphaera cretacea ponticula Bukry, 1969 Leg 14-144-4-1, top.

16: Phase contrast, $3200 \mathrm{X}$, same specimen as Figure 19.

17: Transmitted light, $3200 \times$, same specimen as Figure 19.

18: Cross-polarized light, $3200 \mathrm{X}$, same specimen as Figure 19.

19: Scanning electron micrograph of the distal side, $6000 \times$. 
PLATE 15
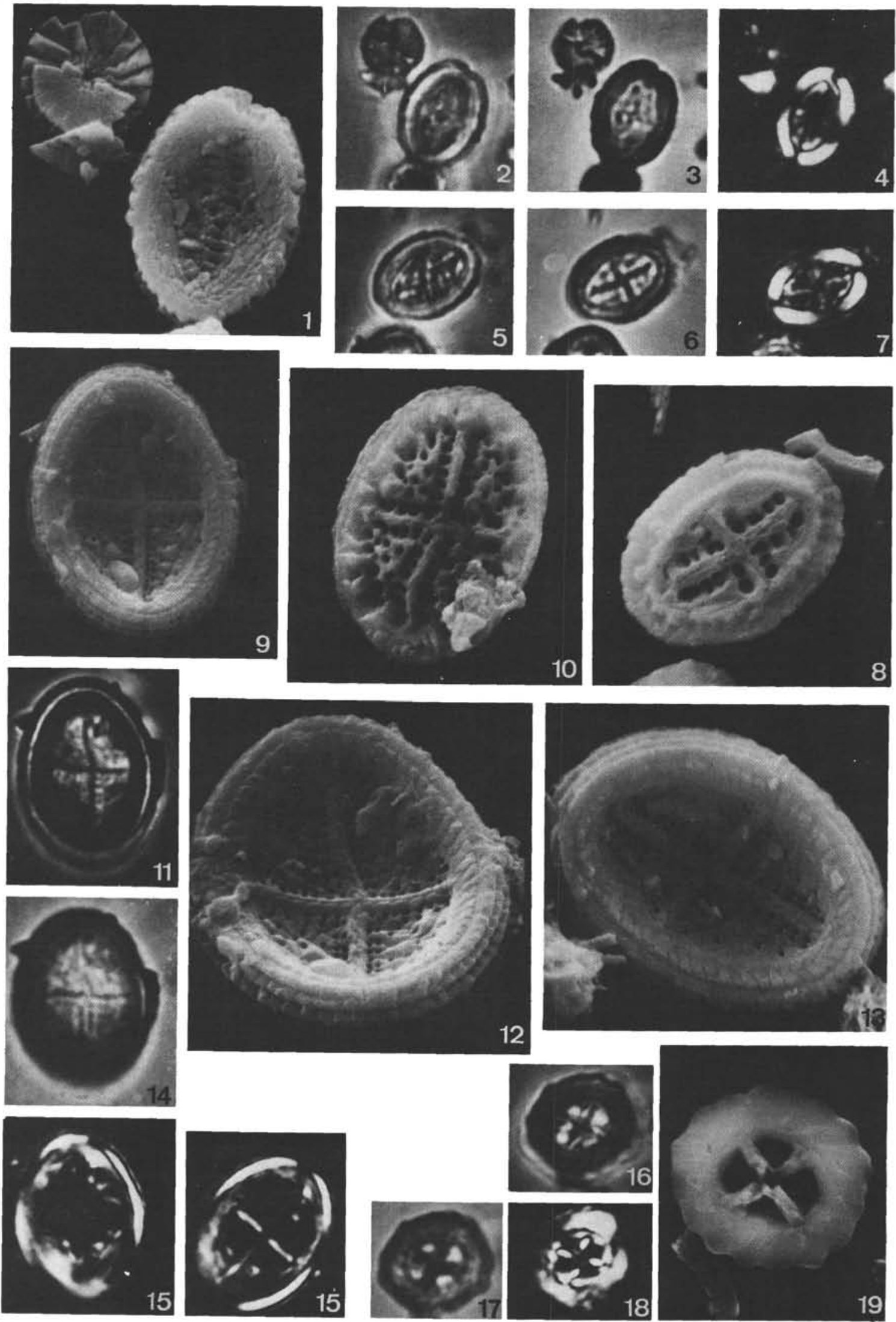


\section{PLATE 16}

Figures 1-4 Prediscosphaera cretacea ponticula Bukry, 1969 Leg 14-144A-5-1, $125-127 \mathrm{~cm}$.

1: Scanning electron micrograph of the proximal side, $6500 \times$.

2: Phase contrast, $3200 \mathrm{X}$, same specimen as Figure 1.

3: Transmitted light, $3200 \mathrm{X}$, same specimen as Figure 1.

4: Cross-polarized light, $3200 \times$, same specimen as Figure 1.

Figure $5 \quad$ Prediscosphaera cretacea cretacea (Arkhangelsky, 1912) Bukry, 1969 Scanning electron micrograph of the proximal side, $6500 \times$, Leg $14-144 \mathrm{~A}-5-1,125-127 \mathrm{~cm}$.

Figures 6-11 Stephanolithion laffittei Noel, 1957 Leg 14-135-9-2, $21 \mathrm{~cm}$.

6: Scanning electron micrograph of the proximal side, $6500 \mathrm{X}$.

7: Scanning electron micrograph of the distal side, $6500 \times$.

8: Scanning electron micrograph of the distal side, $60^{\circ}$ inclined, $6500 \times$, same specimen as Figure 7.

9: Phase contrast, $3200 \times$.

10: Transmitted light, $3200 \mathrm{X}$, same specimen as Figure 9.

11: Cross-polarized light, $3200 \times$, same specimen as Figure 9.

Figures 12-19 Lithastrinus grilli Stradner, 1962 Leg 14-144A-5-1, $125 \mathrm{~cm}$.

12: Phase contrast, high focus, $3200 \mathrm{X}$, same specimen as Figure 14.

13: Phase contrast, low focus, $3200 \mathrm{X}$, same specimen as Figure 14.

14: Scanning electron micrograph of the proximal side, $6500 \times$, hypotype [4398] A936.

15: Transmitted light, $3200 \mathrm{X}$, same specimen as Figure 14.

16: Cross-polarized light, $3200 X$, same specimen as Figure 14.

17: Scanning electron micrograph, side view, $6500 \times$.

Figure 18 Braarudosphaera africana Stradner, 1961

Scanning electron micrograph, $6500 \times$, Leg 14-144-5-1, top.

Figures 19-22 Cyclagelosphaera margareli Noel, 1965 Leg 14-135-9-2, 21-23 cm.

19: Scanning electron micrograph of the distal side, $13,000 \mathrm{X}$.

20: Phase contrast, $3200 \times$, same specimen as Figure 19.

21: Transmitted light, $3200 \mathrm{X}$, same specimen as Figure 19.

22: Cross-polarized light, $3200 \mathrm{X}$, same specimen as Figure 19. 
PLATE 16
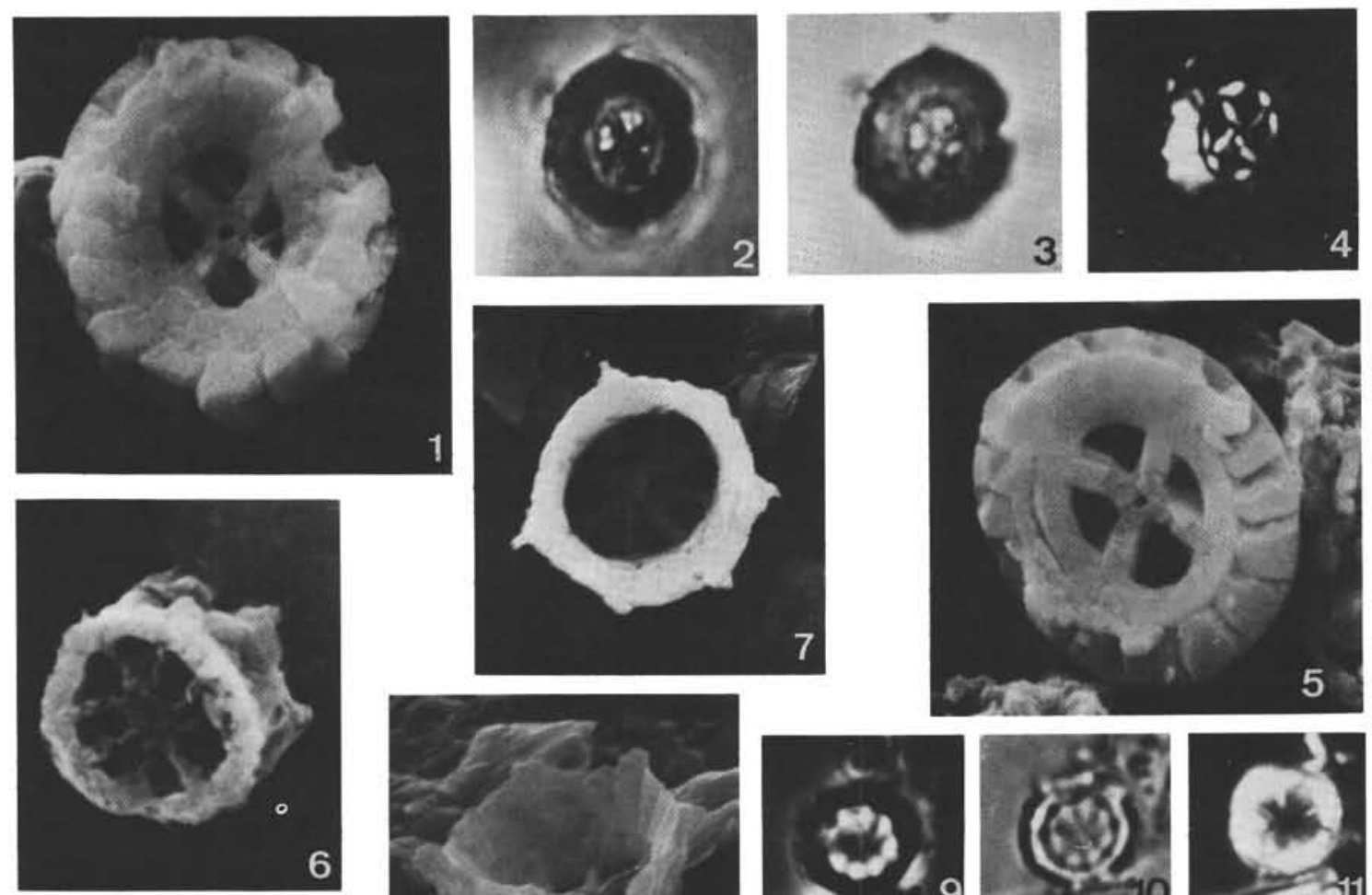

6
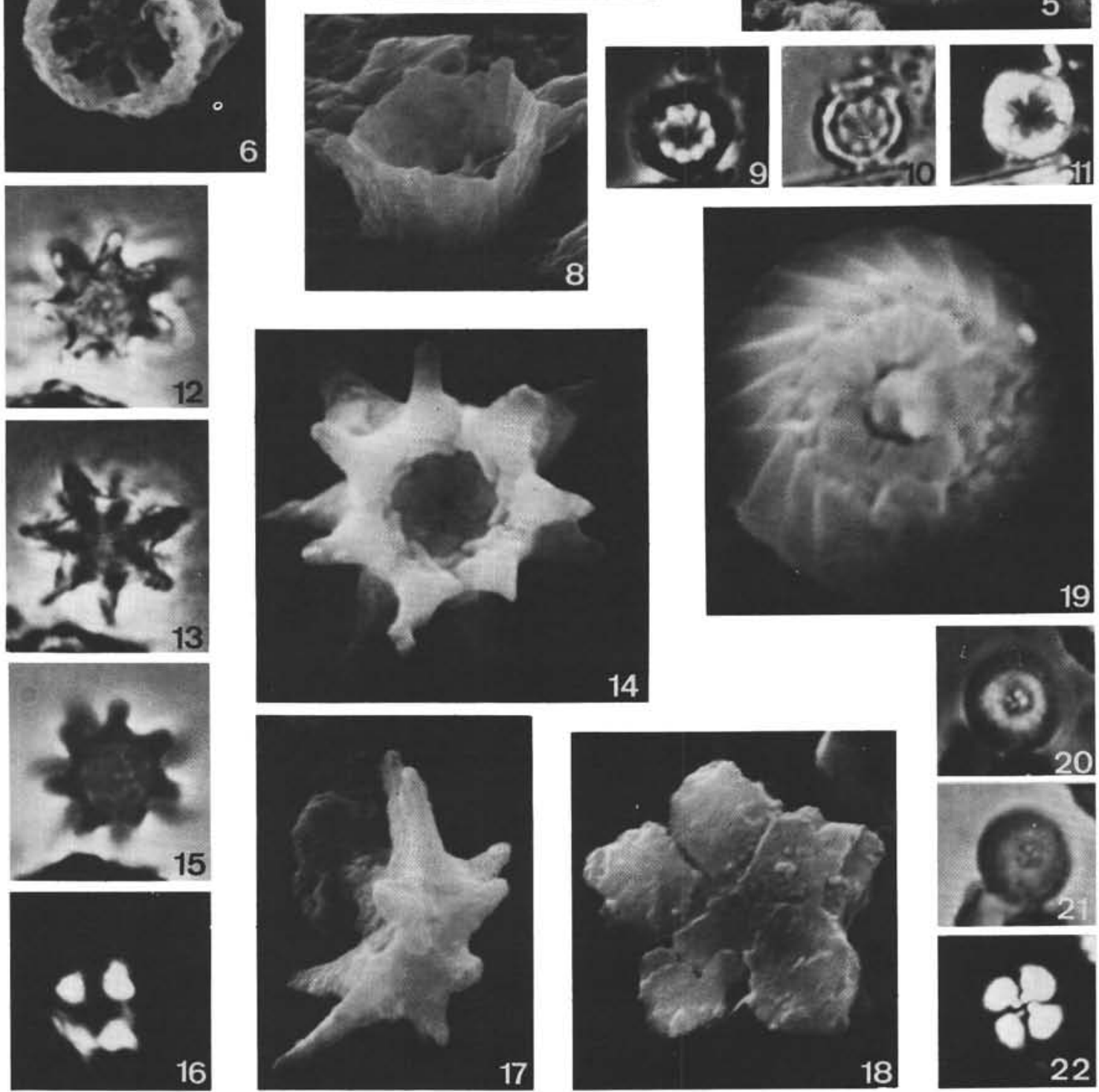

14
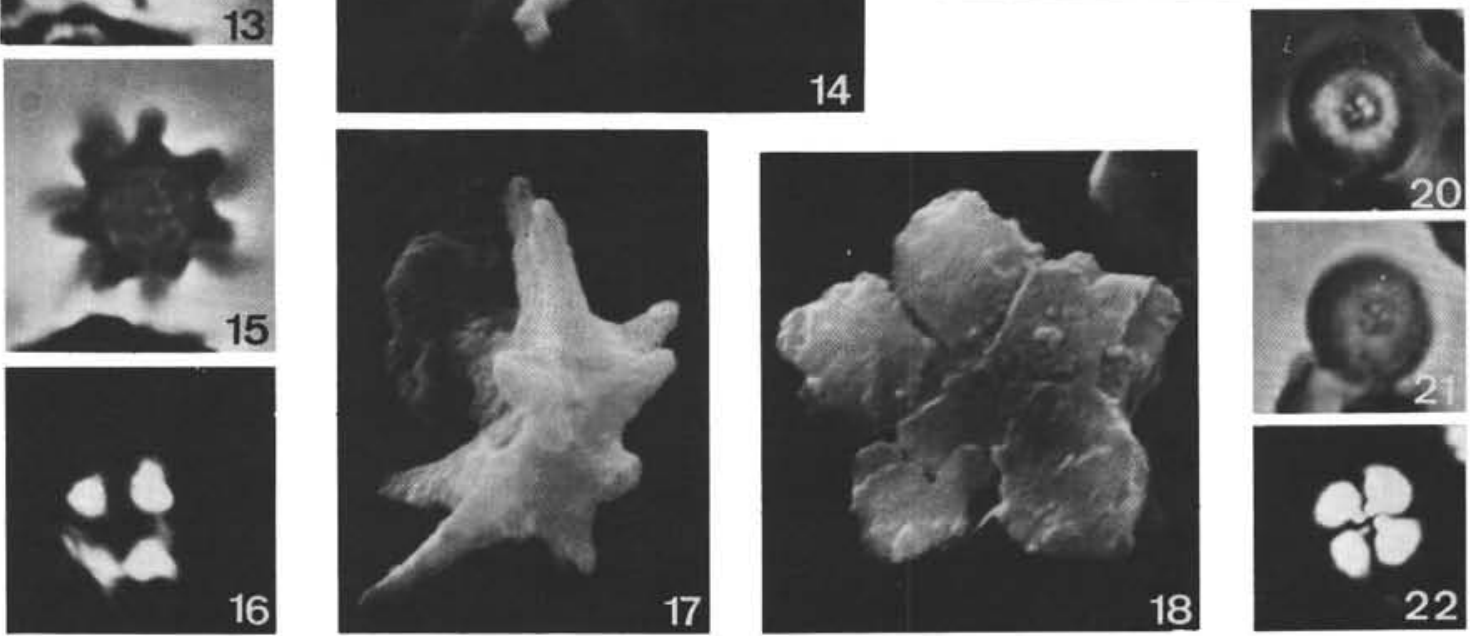